\title{
The Cold War and decolonization in British Guiana: The Anglo- American intervention and Guianese nationalist politics
}

Joshua David Esposito

West Virginia University

Follow this and additional works at: https://researchrepository.wvu.edu/etd

\section{Recommended Citation}

Esposito, Joshua David, "The Cold War and decolonization in British Guiana: The Anglo-American intervention and Guianese nationalist politics" (2010). Graduate Theses, Dissertations, and Problem Reports. 865.

https://researchrepository.wvu.edu/etd/865

This Thesis is protected by copyright and/or related rights. It has been brought to you by the The Research Repository @ WVU with permission from the rights-holder(s). You are free to use this Thesis in any way that is permitted by the copyright and related rights legislation that applies to your use. For other uses you must obtain permission from the rights-holder(s) directly, unless additional rights are indicated by a Creative Commons license in the record and/ or on the work itself. This Thesis has been accepted for inclusion in WVU Graduate Theses, Dissertations, and Problem Reports collection by an authorized administrator of The Research Repository @ WVU. For more information, please contact researchrepository@mail.wvu.edu. 
The Cold War and Decolonization in British Guiana: The Anglo-American Intervention and Guianese Nationalist Politics

Joshua David Esposito

Thesis submitted to the College of Arts and Sciences at West Virginia University in partial fulfillment of requirements

for the degree of

\title{
Master of Arts
}

in

History

\author{
Joseph Hodge, Ph.D., Chair \\ James Siekmeier, Ph.D. \\ SilverMoon, Ph.D. \\ Department of History
}

Morgantown, West Virginia

2010

Keywords: Cold War, decolonization, British Guiana, Cheddi Jagan, British West Indies

Copyright 2010 Joshua David Esposito 


\begin{abstract}
The Cold War and Decolonization in British Guiana: The Anglo-American Intervention and Guianese Nationalist Politics

Joshua David Esposito

This thesis examines the end of colonial rule in British Guiana and what it tells us about the relationship between decolonization and the Cold War. It explores how the end of a four hundred year period of European nation-state domination of the world led to a complex shift in global power structures and considerable conflict. From 1953 to 1966 nationalist leaders in British Guiana struggled to achieve independence from Great Britain and fought to establish their position in the future government of Guyana. Colonialism, however, left a unique imprint on British Guiana's cultural development, and created a volatile society that left the colony marred by racial violence. Additionally, Guianese autonomy was limited by Anglo-American Cold War imperatives in the Caribbean. The decolonization of British Guiana became a struggle, and eventually a compromise, between British and American officials, as well as between the AngloAmerican alliance and Guianese nationalists.

This thesis explores one aspect of that power struggle in detail. It shows how Cheddi Jagan's People's Progressive Party (PPP) in British Guiana pursued an increasingly aggressive foreign policy after the Cuban Revolution in 1959 that was in conflict with United States Cold War goals. Meanwhile, Forbes Burnham and the People's National Congress (PNC) sought to establish a working relationship with the United States. As a result, the United States and Great Britain chose to subvert the elected PPP government and grant independence to British Guiana under a government led by Burnham. The experience of independence in British Guiana illuminates then, the intricate relationship between the Cold War, decolonization, and the struggle for self-government in the developing world.
\end{abstract}




\section{Acknowledgments}

I would like to express my deepest appreciation to Dr. Joseph Hodge and Dr. James Siekmeier. Their guidance has been invaluable and I cannot possibly express enough gratitude for the time they spent reading and providing critical feedback on multiple drafts of this thesis. Their direction is most directly responsible for any measure of career success I may find. I would also like to express appreciation to the West Virginia University history department for providing the opportunity to work as a graduate assistant with Dr. Brian Luskey and Dr. SilverMoon. They are incredible educators and working with them was one of the most valuable experiences of graduate school. I would also like to thank Dr. SilverMoon for being on my thesis committee. I would like to acknowledge a special appreciation for Dr. Robert and Wynona Wilkins for providing a generous endowment which gave me with the opportunity to complete my thesis during the summer.

I wish to express a special appreciation to Karina Garcia for her patience and support while I worked on this project. Her encouragement and perspective were the motivation to work through many challenging moments over the past year. Her perpetually positive nature made it possible to be confident during the most frustrating moments of this thesis.

I would like to acknowledge a special gratitude to Joel Christenson, William Feeney, and David Goldberg for taking the time to provide feedback on various parts of this project and provide advice on the writing process and graduate school in general. I would also like to thank the students from the West Virginia University history graduate department for making the graduate school experience memorable. 
I extend a special appreciation to my parents, Doug and Deb, and my sisters, Shannan and Whitney, for their unrelenting support over the years. Their love and encouragement has been a source of strength throughout life.

I especially want to thank Chase Merritt, Chad Borek, Caleb Foreman, Shane Hanner, Matt Harder, Jody Judson, Leon McCleary, and Jeremy Boyd. My appreciation for you cannot be put into words, and I suspect it does not need to be. Finally, thank you to Eric Horn, Jason Gaitanopoulos, and Hugh Ferry for providing a needed distraction from academics and a mental rejuvenation. 


\section{Table of Contents}

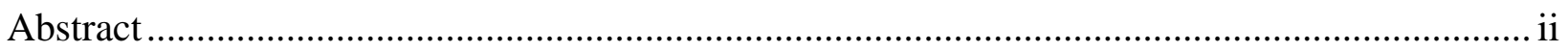

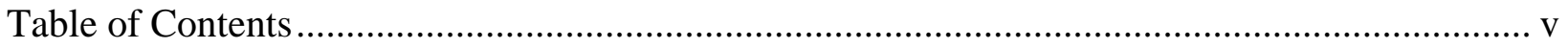

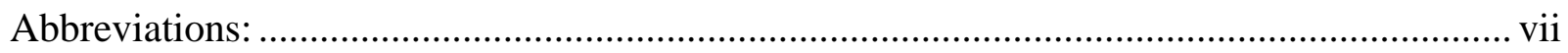

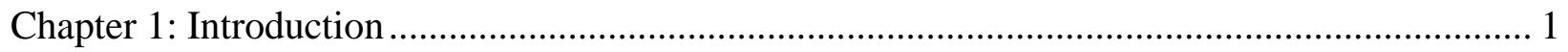

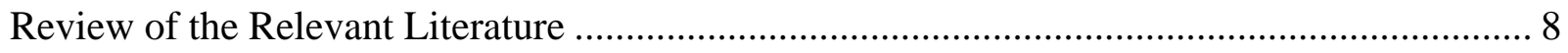

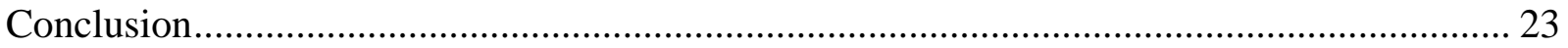

Chapter 2: The Impact of Colonial History on the Decolonization Process in British Guiana .... 25

Initial European Colonization and the Development of a Sugar Economy ………………….... 27

Immigration and Social Development............................................................................... 29

Venezuelan Boarder Dispute.......................................................................................... 32

Colonial Economics in the Early Twentieth Century.................................................................... 33

Organized Labor and Political Evolution................................................................................. 35

Consequences of the Great Depression and World War II on Colonial Development .............. 37

Post-War Political Development............................................................................................. 39

Internal Self-Government and British Resumption of Direct Rule............................................ 43

The Development of Racial Politics in British Guiana .............................................................. 46

The Impact of the Cuban Revolution in British Guiana........................................................... 49

Racial Violence, Anglo-American Intervention, and the Progression to Independence............ 50

Chapter 3: Anglo-American Cooperation and Strategic Objectives During Decolonization in

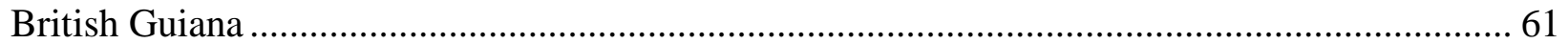

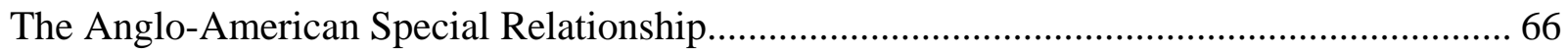

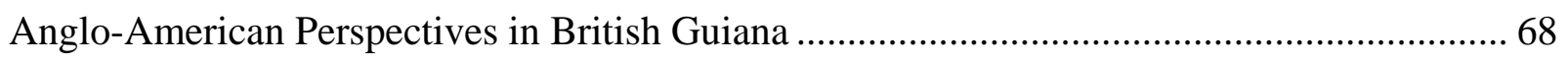

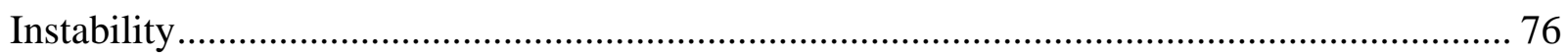

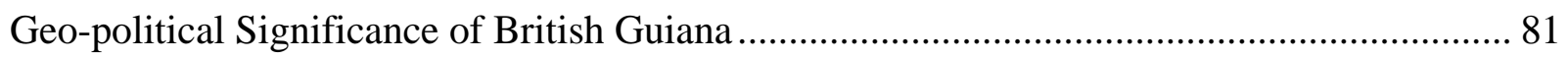

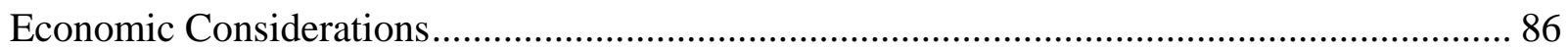

Contention and Cooperation in the Anglo-American Alliance ................................................... 87

Chapter 4: Participants in the Cold War: The Impact of the People's Progressive Party's Foreign Policy in British Guiana.................................................................................................... 95

The Influence of the Cold War on Interpreting Decolonization in British Guiana.................... 96

A Comparison of Latin American Nationalist Leaders During the Early Cold War ............... 100

Contextualizing the Impact of American Subversion in Undermining the PPP Government 104

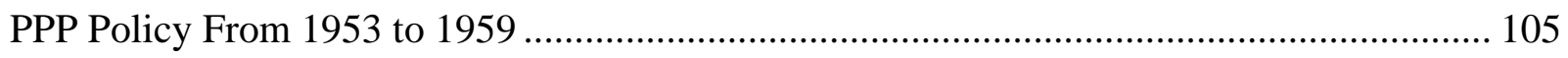

The Increasingly Aggressive PPP Policy After the Cuban Revolution .................................. 109 
The Opportunity and Failure of PPP Policy from August 1961 to June 1962 ...................... 114

The Loss of British Support and the Anglo-American Decision to Remove the PPP ........... 132

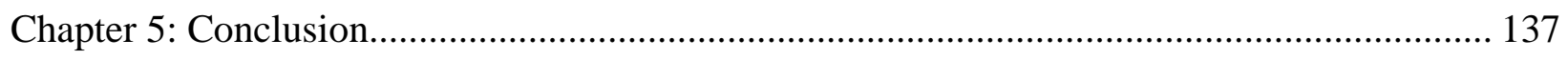

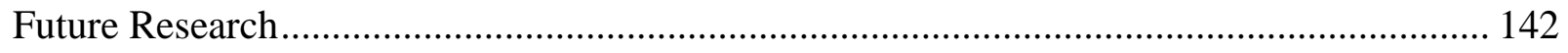




\section{Abbreviations:}

$\mathrm{AD}$

AFL-CIO

BGLU

CIA

CLC

GAWU

GIWU

MPCA

OAS

ORIT

PAC

PNC

PPP

TUC

UF

UN
Accion Democratica (Venezuela)

American Federation of Labor and Congress of Industrial Organizations British Guiana Labour Union

Central Intelligence Agency

Caribbean Labour Congress

Guiana Agricultural Workers Union

Guiana Industrial Workers Union

Manpower Citizens Association

Organization of American States

Inter-American Regional Organization

Political Affairs Committee

People’s National Congress

People’s Progressive Party

Trade Union Council

United Front

United Nations 


\section{Chapter 1: Introduction}

The Twentieth Century was a period of extensive transformation in the global power structure, which had been dominated by European nation states for over four hundred years. Competition between European powers for control of global markets, people, and resources culminated in two massive world wars from 1914-1918 and 1939-1945. Two of the most important consequences of this tumultuous period were the rapid global decolonization of European empires and the Cold War. Most of the former colonized world had achieved, or was well on the way to achieving independence within twenty years of the armistice ending the Second World War in 1945. Simultaneously, the United States and its Western allies were heavily engaged in a conflict with the Soviet Union and the Warsaw Pact nations for ideological, as well as physical, control over the newly autonomous areas. The people of formerly colonized territories sought to take advantage of this international climate, which was hostile to imperialistic policies toward the developing world. People who had been recently under the formal control of empires, as well as others who had been informally controlled by powerful outside influences, attempted to assert their self-interest by appealing to the rhetoric of the postwar international community. Third world nationalism developed as third world peoples asserted what they saw as their right to self-determination asserting that powerful nations should not threaten the sovereignty of developing areas by interfering in their domestic affairs. ${ }^{1}$

\footnotetext{
${ }^{1}$ Benedict Anderson, Imagined Communities: Reflections on the Origin and Spread of Nationalism (London: Verso, 1983); Ronald Hyam, Britain's Declining Empire: The Road to Decolonization, 1918-1968 (Cambridge: Cambridge University Press, 2006). Hyam discusses in detail the impact of international opposition to European colonization on imperial policy in Great Britain. Specifically, he explains how institutions such as the United Nations altered the international community by creating a unified opposition to colonialism and thus further eroded the ability of the British to maintain an empire in light of their weakened post-war economic and military position, hastening the end of formal control of peripheral areas by powerful nations.
} 
However, nationalist leaders frequently discovered that rhetorical overtures and practical actions were not the same, and that powerful nations continued to protect their interests by intervening in developing nations, even while formal empires were fading into the annals of history. The end of European hegemony signaled the beginning of a period of redefinition of international relationships. Thus, conflict was likely as nationalist leaders, former colonizers, and the new leading nations of the international community, the United States and the Soviet Union, competed for supremacy in newly restructured regions.

This thesis will use the independence process in British Guiana from 1953 to 1966 as a microcosm to explore the correlation between the Cold War and post-World War II decolonization. Specifically, it will contextualize the Anglo-American decision to undermine the popularly elected Peoples Progressive Party (PPP) government and its leader, Cheddi Jagan, and in its place, support a regime fronted by Forbes Burnham, who was understood to be racist, irresponsible, and vehemently anti-British. However, what is important was that, at least initially, Burnham was anti-communist. ${ }^{2}$ The British and American decision to intervene in and manipulate local politics was a consequence of the impact of the Cold War and decolonization on policymaking. Additionally, this thesis will examine how the foreign policy decisions of Guianese politicians impacted the British and American policy toward the colony. British Guiana offers a unique opportunity to explore how nationalist leaders and policymakers in the United States and Great Britain struggled with and against each other within the framework of the Cold War as they attempted to reshape the post-colonial world.

\footnotetext{
${ }^{2}$ Melby to Rusk, 20 March, 1962, 841d.06/3-2062, Central Decimal Files Box 2478, RG 59, Records of the Department of State, National Archives II, College Park, MD.
} 
Although studies of the decolonization process in British Guiana have focused on the actions of the United States and Great Britain, this thesis will also examine the considerable impact Guianese leaders had on the development of Anglo-American policy and the overall decolonization process in British Guiana. Scholars such as Stephen Rabe have clearly established that the United States and Great Britain manipulated the decolonization process in British Guiana to achieve a specific political goal, the establishment of a pro-American government after independence. Rabe's work answers the question of how that happened, essentially through intervention by the United States, both physically in British Guiana and diplomatically in Great Britain. ${ }^{3}$ This thesis will not refute that conclusion; rather, it will provide a nuanced explanation of why the United State and Great Britain determined that intervention was necessary to avert a crisis in post-colonial Guyana and why that decision was crucial to regional Cold War strategy. Ultimately, this thesis argues that Guianese leaders pursued foreign policies that actively shaped Anglo-American strategy in British Guiana. This thesis thus reinforces the conclusion reached by scholars such as Odd Arne Westad and Jason Parker, who explain how the interrelated dynamics of the Cold War and global decolonization impacted and were impacted by developing areas of the world. ${ }^{4}$

The first chapter examines how the characteristics of British colonization created the setting for a complex and volatile struggle for an autonomous government in British Guiana. Colonial structures defined immigration, internal migration, as well as economic, social, and political developments in the colony. During the independence period, defined in this thesis as the period between 1953 to1966, opportunistic politicians, primarily Burnham and Jagan

\footnotetext{
${ }^{3}$ Stephen G. Rabe, U.S. Intervention in British Guiana: A Cold War Story (Chapel Hill: The University of North Carolina Press, 2005).

${ }^{4}$ Odd Arne Westad, The Global Cold War: Third World Interventions and the Making of Our Times (Cambridge University Press, Cambridge, UK: 2005), 3; Jason Parker, Brother's Keeper: The United States, Race, and Empire in the British Caribbean, 1937-1962 (Oxford: Oxford University Press, 2008).
} 
exploited ethnic loyalties resulting from the culturally segregated society brought on by colonial development to build their base of support. The consequence of such political measures was a movement toward self-government characterized by racial violence and domestic instability. ${ }^{5}$ Simultaneously, limited suffrage during the colonial period ensured that political organization in British Guiana before 1950 was almost entirely the product of liberal organized labor movements. ${ }^{6}$ The liberal ideology of nationalist leaders in the colony and the connection between international worker movements and national communist parties was a source of concern for the United States during the Cold War as leftist politics became increasingly associated with an international communist conspiracy. ${ }^{7}$ Thus, colonial development created two main challenges for British Guiana as it advanced toward independence from 1953 to1966. First, Guianese leaders and British colonial officials struggled to establish a viable government which could maintain stability and general domestic peace after the withdrawal of British soldiers from the colony. Secondly, Guianese leaders needed to develop a foreign policy which best convinced the United States that mild domestic reforms and relations with communist nations were not a veiled attempt to establish an anti-American, communist government in British Guiana after independence. The general history of colonialism in British Guiana and an overview of the decolonization process provided in chapter one will lay the groundwork for the research of subsequent chapters.

\footnotetext{
${ }^{5}$ There are a number of comprehensive explanations of the connection between colonial development and the independence period in British Guiana. See: Leo A. Despres, Cultural Pluralism and Nationalist Politics in British Guiana (Chicago: Rand McNally and Company, 1967); Cheddi Jagan, The West On Trial: My Fight For Guyana's Freedom (New York: International Publishers, 1966); Rabe, U.S. Intervention in British Guiana; Thomas Spinner, Political and Social History of Guyana 1945-83 (Boulder: Westview Press, 1984).

${ }^{6}$ There are several effective explanations of the impact of organized labor on Guianese politics. See: Robert J. Alexander, A History of Organized Labor in the English -Speaking West Indies (Westport, CT: Praeger, 2004); Kay Saunders, ed. Indentured Labour in the British Empire 1834-1920 (London: Croom Helm Ltd., 1984).

${ }^{7}$ The terms liberal and leftist are used frequently throughout this thesis to describe the political ideology of nationalist leaders in British Guiana and the Caribbean. In short, they refer to the ideological belief in heavy government involvement in social programs and domestic reform. The liberal ideology in Guianese politics was influenced by its origin in workers movements. The United States frequently saw this ideology in Latin America as anti-capitalist and closely related to or easily manipulated by communism.
} 
The second chapter will explore the strategic imperatives of the United States and Great Britain during the period leading up to Guianese independence within the context of the Cold War and global decolonization. The United States interpreted events in British Guiana almost entirely through the prism of a Cold War lens; therefore, American policymaking in the colony was skewed by Cold War geo-strategic imperatives. ${ }^{8}$ There were several factors which convinced the Kennedy and Johnson administrations to make British Guiana a priority. Geographically, the small enclave on mainland South America occupied a critical location for hemispheric defense during the Cold War. British Guiana’s proximity to Venezuela, the main outlet for capital from the United States in Latin America; Brazil, the largest and potentially most powerful nation in South America; the Panama Canal, perhaps the most important point of defense of all for the United States; and the islands of the Caribbean, made it strategically significant despite the diminutive size of the colony. The presence of a modern airfield in the colony made its geographic location even more relevant. However, the overriding concern for the United States in British Guiana was its ideological significance. The progression of the Cuban Revolution toward communism and its eventual alliance with the Soviet Union was an ideological loss that the United States determined to avoid repeating elsewhere in the region. Arthur Schlesinger, special advisor to President John F. Kennedy, described British Guiana as a target of convenience; however from an ideological perspective, it was a target of the utmost priority. ${ }^{9}$

The primary objective of the British Colonial Office in British Guiana was to prepare the colony for independence as quickly and efficiently as possible. Tactically, that meant

\footnotetext{
${ }^{8}$ The direct relationship between American Cold War imperatives and policymaking toward British Guiana is clearly explained by Arthur Schlesinger. See: Arthur M. Schlesinger, Jr., A Thousand Days: John F. Kennedy in the White House (Boston: Houghton Mifflin Company, 1965).

${ }^{9}$ Ibid, 774.
} 
establishing a government capable of sustaining domestic stability and avoiding post-colonial violence similar to events that occurred in India or the Congo ${ }^{10}$ Strategically, however, the foremost objective of the British Foreign Office was the maintenance of a special relationship with the United States, making American regional Cold War anxieties British concerns as well. Maintaining close ties to the United States meant that the British would accede to American demands with regards to the political make-up of the soon to be independent British West Indian territories. Certainly Great Britain had Cold War objectives of its own; however, its association with the United States demanded that American strategy take precedence. Despite considerable disagreements and contentious exchanges between the Colonial Office and Foreign Office, as well as between the United States and Great Britain, in the end the two nations formulated a coherent and unified policy toward British Guiana. ${ }^{11}$ Ultimately, the continuation of the AngloAmerican special relationship proved to be the most important objective of British policy and Colonial Office concerns about the American strategy in British Guiana were overlooked to formulate a cohesive policy with the United States.

The focus of the third chapter is on acknowledging the critical role of Guianese nationalist politicians in influencing Anglo-American policy toward British Guiana. The United States, eventually with British approval, funded subversive attempts against the PPP despite the fact that the party had won all three elections in the colony since the implementation of universal suffrage in 1953. Scholars traditionally attribute the American policy to overzealous anticommunists in Washington who viewed foreign policy through a narrow Cold War lens. Richard

\footnotetext{
10 There was considerable discord and violence which resulted from an ill-conceived process of British decolonization in India . See: Yasim Kahn, The Great Partition: The Making of India and Pakistan (New Haven: Yale University Press, 2007); William Roger Louis, Ends of British Imperialism: The Scramble for Empire, Suez and Decolonization (London: I.B. Tauris, 2006), 496-499,701-702.

${ }^{11}$ The most overtly aggressive exchanges occur between Sir Alec Home of the Foreign Office and Secretary of State Dean Rusk. See: Home to Rusk, 26 February 1962, FRUS 1961-1963, 12:266.
} 
Barnet, for example, explains American Cold War policy as overly rigid when classifying emerging governments, arguing that the presence of some or all of a number of liberal policies was sufficient to establish the basis for opposition to that government from the United States. Most of the characteristics that Barnet identified, including land reform, possible nationalization of private industry, acceptance of Chinese or Soviet aid, and the pursuance of a non-aligned foreign policy, were aspects of PPP strategy in British Guiana. ${ }^{12}$ Similarly, Stephen Rabe interprets American intervention in British Guiana as an overreaction by American officials to domestic reforms, fearing that they were a precursor to communism, and a misunderstanding of the political position of the PPP leadership, specifically Cheddi Jagan. ${ }^{13}$ This thesis does not directly dispute the assertions of these renowned scholars; however, by focusing on the actions of Guianese officials, it does present a more nuanced explanation for events in British Guiana by addressing the actions of Guianese leaders themselves.

Rather than focusing primarily on how Cold War ideology impacted policymakers in the United States, this thesis will explain how leaders in the developing world impacted American foreign policy. In British Guiana, the failure of the PPP to conduct an effective foreign policy, specifically, its inability or unwillingness to work with the United States, was the catalyst for American inspired or directed subversive attempts against party leadership. The Cuban Revolution caused American leaders to fear spreading communism in the Caribbean and influenced PPP leadership to a considerable degree. PPP leadership, specifically Jagan, misinterpreted the consequences of the Cuban Revolution as it related to other Caribbean nations

\footnotetext{
${ }^{12}$ Richard Barnet, Intervention and Revolution: The United States in the Third World (New York: The World Publishing Company, 1968).

${ }^{13}$ Rabe, U.S. Intervention in British Guiana, 78-79, 81-83.
} 
and their alignment in the Cold War. Thus, the PPP engaged in a foreign policy which undermined its position in British Guiana.

Finally, this thesis will challenge the idea that the British decision to undermine the PPP was solely the result of acquiescing to American demands. It suggests rather that Great Britain pursued its own self interest in respect to British Guiana, although American pressure influenced the British decision making process. However, American pressure does not alone explain the British course of action in the colony. Financial concerns and fear of instability in British Guiana played a critical role in determining British policy. This work will examine the PPP's foreign policy and contextualize Cheddi Jagan's political decisions rather than dismiss him as ideologically confused. ${ }^{14}$ Jagan pursued consistent and coherent domestic and foreign policies for twenty years from his earliest involvement in labor movements to his eventual loss of power in 1964. Conversely, after ending his association with Jagan in 1955, Forbes Burnham and the People's National Congress (PNC) courted United States officials effectively and avoided open rhetorical opposition to American leaders or association with communist nations. Ultimately, the third chapter will explain how the foreign policy conducted by Guianese leaders largely determined the outcome of events in British Guiana.

\section{Review of the Relevant Literature}

This thesis speaks to a broad historiography in developing a comprehensive analysis of the relationship between British Guiana, the United States, and Great Britain during the Cold War and decolonization. Specifically, it will address the historical literature concerning the special relationship between the United States and Great Britain during the Cold War, the Cold

\footnotetext{
${ }^{14}$ Rabe, U.S. Intervention in British Guiana, 78.
} 
War in general, British decolonization, British Guiana, United States-Latin American relations, and the role of nationalist leaders in the developing world. One of the key aspects of the Cold War was the special relationship that developed between the United States and Great Britain, forged in the anti-Axis struggle of World War II, but maintained after the Second World War to more effectively combat the perceived threat from the Soviet Union and international communism. From the perspective of Great Britain and the United States, the soon to be independent colonies were not prepared for self-rule until their incoming governments were evaluated within a Cold War strategic context. It was necessary for former colonies to show that they could successfully repel any communist influence within their nation, which implied, primarily, the ability to maintain internal stability and willing alignment with the West. A number of authors have effectively discussed the importance of international relations in British decolonization. Ronald Hyam's Britain's Declining Empire adequately explains the implications of the post-World War II international setting and the effects of organizations such as the United Nations on influencing Great Britain’s colonial policies. He contextualizes the major factors leading to the dissolution of the British Empire within the international community, while discussing several areas which decolonized in an exceptional manner, such as British Guiana. Hyam discusses the interplay between the United States and Great Britain, specifically the paradox between British attempts to cultivate a special relationship with the United States while maintaining the ability to act independently of their America counterparts. ${ }^{15}$

Like Hyam, William Roger Louis acknowledges the primacy of international affairs in determining the direction of British decolonization. In Ends of British Imperialism, Louis discusses the evolution of the principle of self-determination for British colonies during the early

\footnotetext{
${ }^{15}$ Hyam, Britain’s Declining Empire,12-14.
} 
to middle twentieth century from the mandates system of the League of Nations to the trusteeship system of the United Nations. Louis suggests that one of the most significant factors leading to decolonization was the reinterpretation of the meaning of self-determination from a manner of extending moderate autonomy to colonized regions to political independence for European colonies. Louis also notes that a key characteristic of decolonization was the British attempt to maintain influence in former colonial areas, in part through cooperation with the United States and the strategic use of American aid to developing areas. ${ }^{16}$ Louis further contextualizes the United States pursuit of trusteeship during and after World War II and its implications for the future of the British Empire in Imperialism at Bay ${ }^{17}$ Many of the same issues that impacted the special relationship between Great Britain and the United States during the decolonization process in British Guiana began during the diplomatic wrangling of the Second World War. Specifically, Franklin Roosevelt's firm anti-colonial stance created tensions between the United States and Great Britain before the rise of the Soviet Union in 1943 and led to a re-evaluation of American policy toward colonial areas. Louis suggests that in mid-1943 the United States began pursuing a policy of military security which led to occasional support for the British imperial system as a counter to growing Soviet influence. ${ }^{18}$ Fifteen years later, the United States still struggled with balancing rhetorical support for colonial self-determination with American security concerns in British Guiana. Louis also notes the use of the lend-lease agreements with Great Britain as a means of advancing American interests during World War

\footnotetext{
${ }^{16}$ Louis, Ends of British Imperialism, xi, 26-29.

${ }^{17}$ William Roger Louis, Imperialism at Bay: The United States and the Decolonization of the British Empire 194145 (New York: Oxford University Press, 1978).

${ }^{18}$ Ibid, 537, 567.
} 
II. ${ }^{19}$ The United States used similar economic enticements to help convince the British to support Forbes Burnham in $1963 .^{20}$

In addition to Louis, Christopher Thorne’s Allies of a Kind also considers the contentious aspects of the Anglo-American alliance during World War II. Thorne suggests that the maintenance of the Anglo-American alliance took precedence over either nation's individual interests. $^{21}$ In British Guiana, British and American decisions were impacted at every turn by the significance of continuing a cooperative Anglo-American relationship during the Cold War. In Bitter Rehearsal , Charlie Whitham discusses the dialog between the United States and Great Britain during and immediately after the Second World War and how it set the tone for decolonization in the West Indies twenty years later. ${ }^{22}$

Traditionally, scholars have defined the Cold War as an East-West struggle for political supremacy in which the main actors were the United States and its Western European allies, and the Soviet Union and the Eastern bloc. Increasingly, however, historians have expanded thought on the subject to include what were originally considered peripheral, third world, or developing nations. ${ }^{23}$ The increased study of developing nations has shifted the focus of the Cold War from East-West relations to a more complex East-West-North-South dynamic, explained best in Odd Arne Westad's The Global Cold War, as well as by Jason Parker, and Gerald Horne. ${ }^{24}$ Westad considers the role of superpowers, primarily the United States and the Soviet Union, in impacting the post-colonial development of former European colonies; while at the same time

\footnotetext{
${ }^{19}$ Ibid, 566.

${ }^{20}$ Memorandum of Conversation at Birch Grove, England, 30 June 1963, FRUS, 1961-1963, 12:295.

${ }^{21}$ Christopher Thorne, Allies of a Kind: The United States, Britain and the war against Japan, 1941-45 (New York: Oxford University Press, 1978).

${ }^{22}$ Charlie Whitham, Bitter Rehearsal: British and American Planning for a Post-War West Indies (London: Praeger Publishers, 2002).

${ }^{23}$ The terms, third world, peripheral, and developing areas have all been used to describe former colonial regions. The term developing areas will be used for the purposes of this thesis.

${ }^{24}$ Westad, The Global Cold War, 3; Parker, Brother's Keeper; Horne, Cold War in a Hot Zone.
} 
acknowledging the ways in which developing nations established political agendas in response to superpower intervention. ${ }^{25}$ Matthew Connelly’s A Diplomatic Revolution considers the close relationship between the Cold War and decolonization, specifically the significance of international relations and non-governmental institutions in influencing colonial powers and creating the post-colonial world. Connelly also considers the critical role of nationalist leaders in impacting colonial policy. ${ }^{26}$

Several academics who specialize in the history of inter-American relations have conducted similar studies of individuals. Eric Roorda’s The Dictator Next Door evaluates the ways in which Rafael Trujillo maintained power in the Dominican Republic, despite oppressive dictatorial policies and the massacre of about 12,000 Haitians by establishing a working relationship with the United States. ${ }^{27}$ Kyle Longley describes a similar relationship between Jose Figueres in Costa Rica and the United States in The Sparrow and the Hawk. Figueres engaged in the type domestic reform policies, specifically land reform, which resulted in United States intervention in other Latin American nations such as Guatemala and British Guiana. However, a well-established cooperative relationship with the United States enabled him to undergo those changes without the same reprisals from Washington. ${ }^{28}$ Roorda and Longley describe how establishing pro-United States, rather than non-aligned foreign policies, allowed regional leaders to pursue domestic policies with minimal fear of American intervention.

\footnotetext{
${ }^{25}$ Westad, The Global Cold War.

${ }^{26}$ Matthew Connelly, A Diplomatic Revolution: Algeria's Fight for Independence and the Origins of the Post-Cold War Era (Oxford: Oxford University Press, 2002).

${ }^{27}$ Eric Paul Roorda, The Dictator Next Door: The Good Neighbor Policy and the Trujillo Regime in the Dominican Republic, 1930-1945 (Durham: Duke University Press, 1998), 126.

${ }^{28}$ Kyle Longley, The Sparrow and the Hawk: Costa Rica and the United States During the Rise of Jose Figueres (Tuscaloosa: The University of Alabama Press, 1997).
} 
Colin Palmer's Eric Williams and the Making of the Modern Caribbean examines the crucial role of Eric William, the Prime Minister of Trinidad and Tobago, in shaping the postcolonial Caribbean. ${ }^{29}$ Williams was a central figure in the British West Indies during the period covered in this thesis, both as an academic and political leader and Palmer provides evidence of Williams' insights on several important aspects of the independence process in British Guiana. Specifically, he notes that Williams was concerned about the prospect of prematurely granting independence in British Guiana, in large part because Jagan and Burnham were more concerned with pursuing their own personal political ambitions than cooperating to end racial strife and prepare the colony for self-government. ${ }^{30}$ Thus, Westad, Palmer, Connelly, Longley, and Roorda, have begun to acknowledge the critical role of political leaders and political and social groups in the developing world in effecting the trajectory of the Cold War-decolonization era. This thesis will build on their work by showing how nationalist leaders influenced Anglo-American policy towards British Guiana.

Charles Ameringer's The Democratic Left in Exile suggests that individuals, such as Figueres, were part of a broad Latin American movement which embraced revolutionary political ideology as a means of challenging the existing political structure in the region, namely, the authority of dictators, such as Trujillo. ${ }^{31}$ Ameringer's work argues that the Caribbean underwent significant political and social change between World War I and the Cuban Revolution, in part because of the influence of revolutionary movements in Mexico and the

\footnotetext{
${ }^{29}$ For a summary of Williams' relationship to Guianese politics, and his evaluation of Jagan and Burnham , see: Colin A. Palmer, Eric Williams and the Making of the Modern Caribbean (Chapel Hill: The University of North Carolina Press, 2006), 198-234.

${ }^{30}$ Ibid, 205, 222.

${ }^{31}$ Charles Ameringer, The Democratic Left in Exile: The Antidictatorial Struggle in the Caribbean, 1945-59 (Coral Gables, FL, 1974).
} 
Soviet Union. ${ }^{32}$ In examining the collaboration between regional leaders, Ameringer illustrates how, at times, there was a fine line between the democratic left and communist regimes. ${ }^{33}$ Most significantly, the success of the Cuban Revolution was the catalyst for a reinterpretation of the ideology which had guided the Democratic Left since 1945 and a re-evaluation of the movement's goals. ${ }^{34}$ This is perhaps most clear in Venezuela, where a schism developed between moderate, older members of the Accion Democratica (AD), and the younger, more radical, "muchachos". ${ }^{35}$ Thomas Wright further explores the impact of the Cuban Revolution on regional ideology and political movements in Latin America in the Era of the Cuban Revolution. ${ }^{36}$ Wright suggests that after the split in the AD, the Venezuelan Communist Party became the most active communist party in Latin America and in 1962 it formally embraced armed struggle against the existing Venezuelan government. ${ }^{37}$ The work of Ameringer and Wright further proves that Caribbean activists and nationalist leaders were active participants in the Cold War, not simply pawns in a struggle between the United States and the Soviet Union. This thesis will build on their work by showing that Guianese nationalists were influenced by the Cold War. Additionally, it will examine how Cheddi Jagan and Forbes Burnham developed foreign policies based on their perception of the impact of Cold War events in British Guiana.

\footnotetext{
${ }^{32}$ Ibid, 19-20.

${ }^{33}$ Throughout his work, Ameringer chronicles the relationships of regional leaders who struggled against Caribbean dictatorships. What becomes clear in his work, that is essential for the purposes of this thesis, is that while the Democratic Left was generally anti-communist, the relationship was never black and white. In discussing the future of Latin American dictatorships at the Santiago Conference in 1959, the Venezuelan delegation sided most closely with the representatives from Cuba. At the time, the Venezuelan contingency sought to promote leftist democracy; however, its interpretation of how to achieve needed regional reforms was closer to the Cuban model than that of moderate democratic regimes, such as Brasil or the United States. See: Ibid, 284-289.

${ }^{34}$ Ameringer defines the Democratic Left as embracing the ideals of equal rights and representative government and seeking far-reaching economic and social change, national planning for economic planning and diversification, an equitable distribution of wealth, liberation of the economy from foreign control, agrarian reform, and improved housing, education, and health care. See: Ibid, 15.

${ }^{35}$ Ibid, 289-293.

${ }^{36}$ Thomas C. Wright, Latin America in the Era of the Cuban Revolution (Westport, CT: Praeger, 2001).

${ }^{37}$ Ibid, 52, 78.
} 
However active regional leaders were, the United States was the most powerful nation in the region and its policies impacted every facet of regional politics during the Cold War. There has been considerable research into United States Cold War policy as it relates to the Caribbean and Latin America. Richard Barnet is critical of American policy, which he interprets as an overly strict adherence to anti-communism. Barnet suggests that United States officials had difficulty making foreign policy decisions because their worldview was obscured by a Cold War lens. ${ }^{38}$ Similarly, Stephen Rabe is critical of United States policy toward British Guiana. He suggests that the Kennedy Administration's inflexible Cold War agenda did not permit a realistic understanding of the subtleties of the Guianese political situation. ${ }^{39}$ Arthur Schlesinger's A Thousand Days provides key insight into Kennedy Administration policymaking in the hemisphere as well as important contextualization of the internal dynamics of the White House from 1961-1963. Most importantly for the purposes of this study, Schlesinger, a historian who served in the John F. Kennedy Administration, describes how the Cuban Revolution, the failed Bay of Pigs invasion, and the Cuban Missile Crisis impacted policymaking toward British Guiana. Schlesinger's explains that the primary objective of American policy toward the Caribbean was to avoid a second communist revolution. Crucially, however, Schlesinger notes that Kennedy sought to carry out a pragmatic policy in the hemisphere after the Bay of Pigs disaster, potentially working with governments of varying ideologies and domestic agendas, as long as they were anti-communist. Schlesinger's description of White House policymaking suggests that interpretations which attribute the PPP failure in British Guiana to a paranoid anticommunist policy are incomplete. ${ }^{40}$ Schlesinger's work suggests that hemispheric leaders could engage in a degree of independent domestic policymaking, as suggested by Kyle Longley in The

\footnotetext{
${ }^{38}$ Barnet, Intervention and Revolution, 257.

${ }^{39}$ Rabe, U.S. Intervention in British Guiana 71-73.

${ }^{40}$ Schlesinger, A Thousand Days, 773-781.
} 
Sparrow and the Hawk and Eric Roorda's The Dictator Next Door, so long as they supported American opposition to communism, specifically in the Western Hemisphere. ${ }^{41}$

Nonetheless, a critical component of United States Cold War policy in Latin America, and much of the developing world, was covert intervention. Philip Agee's Inside the Company is an early depiction of Central Intelligence Agency (CIA) intervention. Agee, a former CIA agent, discusses how the United States government, with the assistance of the American Federation of Labor and Congress of Industrial Organizations (AFL-CIO), conducted operations to subvert the Jagan-led PPP beginning in 1959. ${ }^{42}$ In addition to Agee, James McDonald, Nick Cullather, Jennifer Dale Kibe, and Gordon Oliver Daniels, have produced important studies which have contributed to the understanding of American covert subversion activities. ${ }^{43}$

Anglo-American intervention significantly influenced decolonization in British Guiana; however, British Guiana’s colonial history created the social and political setting which British and American policymakers exploited as the colony transitioned to self-government. The secondary literature on the development of Guianese culture begins with Leo Despres’ Cultural Pluralism and Nationalist Politics in British Guiana who explains the instability of the Guianese independence period as a consequence of the sociological development of the colony. ${ }^{44} \mathrm{He}$ attributes the physical as well as cultural separation of ethnic groups in British Guiana, specifically the Afro-Guianese and East Indian communities, to colonial development. Despres argues that the Christian missionary run educational system alienated East Indians seeking to

${ }^{41}$ Longley, The Sparrow and the Hawk; Roorda, The Dictator Next Door.

${ }^{42}$ Philip Agee, Inside the Company: CIA Diary (New York: Bantam Books, 1975), 416.

${ }^{43}$ James L. McDonald, "Overriding Interests: Subversion as an Instrument of U.S. Foreign Policy” (Ph.D. diss., American University, 1997); Nick Cullather, Secret History: The CIA's Classified Account of its Operations in Guatemala, 1952-54 (Stanford, California: Stanford University Press, 1999); Jennifer Dale Kibe, "Presidents as Kingmakers: U.S. Decisions to Overthrow Foreign Governments” (Ph.D. Diss., University of California Los Angeles, 2002); Gordon Oliver Daniels, "A Great Injustice to Cheddi Jagan: The Kennedy Administration and British Guiana, 1961-63” (Ph.D. Diss., University of Mississippi, 2000).

${ }^{44}$ Despres, Cultural Pluralism and Nationalist Politics in British Guiana. 
preserve their Hindu culture. He emphasizes that the physical separation of Afro-Guianese, who primarily resided in urban areas, and East Indians, who mostly remained on rural plantations, led to the emergence of a culturally pluralistic society in British Guiana. ${ }^{45}$ Despres asserts that cultural pluralism was the basis for eventual strife as the nationalist movement progressed. He concludes that the culturally pluralistic nature of Guianese society and the willingness of politicians, specifically Jagan and Burnham, to exploit racial differences for political advantage, were the primary factors which destroyed the unified nationalist movement in the colony and defined the independence period. ${ }^{46}$ Rishee Thakur takes issue with Despres and traditional cultural pluralists who subordinate the important role of political ideology among third world nationalists to simplistic cultural explanations. He contextualizes cultural pluralism as the Caribbean variant of Modernization Theory. ${ }^{47}$ Although cultural divisions existed in Guianese society, their ability to fragment the nationalist movement was significant only within the broader context of political and ideological differences within the movement itself. Thakur concludes that most of the racial violence was a manufactured product of Jagan and Burnham’s political maneuvering and of American subversion efforts. ${ }^{48}$

Alan H. Adamson describes the early development of British Guiana’s political economy as the result of indentured immigration to the colony in the aftermath of the emancipation of slaves in the British Empire in 1834 in Indentured Labour in the British Empire 1834-1920.

\footnotetext{
${ }^{45}$ Despres defines a pluralistic society as one in which two or more societal groups coexist with minimal interrelation. Groups remain culturally differentiated through specific institutional activities which maintain cultural differentiation as the basis for socio-cultural integration. See: Ibid, 13-14, 21-23.

${ }^{46}$ Ibid ,220-224.

${ }^{47}$ Michael Latham defines modernization theory as a set of assumptions, essentially: 1. Traditional and modern societies are separated by a sharp dichotomy; 2. Economic, political, and social changes are integrated and interdependent; 3. Development tends to proceed toward the modern state along a common, linear path; and 4 . The progress of developing societies can be dramatically accelerated through contact with developed ones. See: Michael E. Latham, Modernization as Ideology: American Social Science and "Nation Building" in the Kennedy Era (Chapel Hill: The University of North Carolina Press, 2000), 4.

${ }^{48}$ Rishee S. Thakur, "Politics and Hegemony in Guianese Nationalism, 1945-1965” (Ph.D. Diss., York University, 1994).
} 
Adamson concludes that the system of indentured servitude in British Guiana resulted in an economic monoculture based on sugar and, like Despres, a culturally pluralistic society. ${ }^{49}$ In $A$ History of Organized Labor in the English-Speaking West Indies, Robert J. Alexander examines how the political development of British Guiana, as with most of the British West Indies, grew out of organized labor movements. ${ }^{50}$ Alexander describes how severe limitations on suffrage in the colony forced the majority of the population to seek political voice through labor unions. However, as suffrage expanded unions maintained considerable influence over political parties and parties sought to develop alliances with established unions or replace them with organizations loyal to the parties themselves.

The intimate relationship between organized labor and political parties was the impetus for much of the conflict and violence of the independence period. ${ }^{51}$ In Cold War in a Hot Zone, Gerald Horne describes how organized labor in the British West Indies played a critical role in influencing the timing and trajectory of independence movements in the Caribbean after World War II. Horne explains that radical labor movements were the impetus for political organization throughout the region as well as the source of considerable strife with the United States and Great Britain. ${ }^{52}$ The radical Marxist ideology of many regional movements, specifically the Caribbean Labour Congress (CLC), was incompatible with British colonial and American Cold War imperatives in the hemisphere, and thus led to Anglo-American intervention. Additionally,

\footnotetext{
${ }^{49}$ Alan H. Adamson, “The Impact of Indentured Immigration on the Political Economy of British Guiana” in Saunders, Indentured Labour in the British Empire 1834-1920, 53.

${ }^{50}$ Alexander, A History of Organized Labor in the English -Speaking West Indies.

${ }^{51}$ Ibid, 330, 368-370.

${ }^{52}$ Horne, Cold War in a Hot Zone.
} 
Horne elaborates on the racial politics within British Guiana which led to the disintegration of unified labor movements in the colony. ${ }^{53}$

The secondary literature on the decolonization and independence of British Guiana tends to focus on the involvement of the United States in the overthrow of Cheddi Jagan and the general decolonization process of the British West Indies. Early interpretations of the independence process in British Guiana, such as Cheddi Jagan's The West On Trial, interpreted events in the colony during the independence period as part of a Cold War struggle wherein the Guianese became victims of overzealous anti-communists within the United States government. Jagan's autobiography attributes the violence of the independence process in British Guiana, and ultimately the failure of the PPP government to remain in power, to subversive efforts by the Central Intelligence Agency (CIA) and the Kennedy administration. ${ }^{54}$ Richard Barnet’s Intervention and Revolution echoes Jagan's argument, concluding that land reform measures, acceptance of aid from communist nations, and the PPP attempt to formulate a non-aligned foreign policy, caused United States officials to assume that the Guianese government was a threat to American national security, which in turn, led to covert intervention in the colony. ${ }^{55}$ Barnet's work is an early criticism of the tendency of American policymakers to view the world through a narrow Cold War lens. ${ }^{56}$ Thomas Spinner's Political and Social History of Guyana 1945-83 draws similar conclusions to Jagan and Barnet. ${ }^{57}$ Spinner describes Jagan as a "romantic

\footnotetext{
${ }^{53}$ Ibid, 157, 171-172.

${ }^{54}$ Jagan, The West On Trial.

${ }^{55}$ Barnet, Intervention and Revolution, 106.

${ }^{56}$ Ibid, 9-10.

${ }^{57}$ Spinner, Political and Social History of Guyana.
} 
Stalinist” unjustly removed from his position by a Kennedy Administration obsessed with avoiding a Cuban-like revolution in British Guiana. ${ }^{58}$

More recently, Stephen Rabe's U.S. Intervention in British Guiana, determines that in the wake of the Cuban Revolution, the Kennedy Administration's fear of confronting a communist government in the hemisphere resulted in an inflexible and irrational policy of covert subversion toward a moderate PPP government in British Guiana. Rabe analyzes the interaction between the Kennedy Administration and high ranking officials in Great Britain, concluding that the British bowed to American pressure and assisted in destroying democracy in their colony to achieve American Cold War aims. He also considers the role of non-governmental actors, specifically American labor unions such as the American Federation of Labor-Congress of Industrial Organization (AFL-CIO), to add depth to the conclusions drawn from earlier works. ${ }^{59}$ Rabe provides a more focused analysis of United States anti-communist policymaking toward Latin America under the administration of President John F. Kennedy in The Most Dangerous Area in the World. ${ }^{60}$ Similarly, Gordon Oliver Daniels’ “A Great Injustice to Cheddi Jagan” suggests that British and American opposition to Cheddi Jagan was unjustified. Daniels suggests that Jagan was a nationalist, who British and American officials deemed communist because of his aggressive attempts to achieve independence for the Guianese people. ${ }^{61}$ Daniels acknowledges that Jagan's “reckless diplomacy” had a considerably negative impact on his relationship with American officials; however, he concludes that the Kennedy Administration's strict Cold War

\footnotetext{
58 Ibid, xii.

${ }^{59}$ Rabe, U.S. Intervention in British Guiana, 11.

${ }^{60}$ Rabe also considers the Kennedy Administration policy toward British Guiana in an earlier work . See: Stephen Rabe, The Most Dangerous Area in the World: John F. Kennedy Confronts Communist Revolution in Latin America (Chapel Hill: The University of North Carolina Press, 1999). 79-95.

${ }^{61}$ Daniels, “A Great Injustice to Cheddi Jagan”, 1.
} 
policy drove events in British Guiana. ${ }^{62}$ Rabe and Daniels show the significant influence of American intervention in British Guiana, and this thesis will seek to add to their work by explaining how Jagan influenced British and American policy in British Guiana.

Finally, Jason Parker best explores the role of race in the decolonization of the Caribbean. Brother's Keeper contributes substantially to the understanding of the roles of race and the Cold War during the decolonization process in the British West Indies. Parker, like Gerald Horne, considers the relationship between British and American imperatives in the Caribbean. He elaborates on how the United States and Great Britain worked together to maintain stability in the region, diffusing potentially volatile independence movements as power was transferred from colonial power to newly emerging governments. ${ }^{63}$ Additionally, Parker discusses how black Caribbean leaders such as Marcus Garvey and Norman Manley helped forge political ties between the British West Indies and the American civil rights movement, which had a growing influence on domestic politics in the United States. ${ }^{64}$ Thus, domestic racial politics made it somewhat difficult for United States policymakers to oppose regional leaders of African descent. Like Parker, Odd Arne Westad's The Global Cold War considers the interconnectedness of the Cold War and decolonization and exemplifies the trajectory toward a more inclusive literature involving actors in developing areas as well as superpower nations. ${ }^{65}$ This thesis briefly explains how domestic politics in the United States impacted the Kennedy Administration policy toward British Guiana, and thus, shows how nationalist leaders engaged the American public as a means of influencing policymakers in Washington.

\footnotetext{
${ }^{62}$ Ibid, 124-125, 168-172.

${ }^{63}$ Parker, Brother's Keeper; Gerald Horne, Cold War in a Hot Zone: The United States Confronts Labor and Independence Struggles in the British West Indies (Philadelphia: Temple University Press, 2007).

${ }^{64}$ Ibid, 6, 16-17, 43, 53.

${ }^{65}$ Westad, The Global Cold War, 5.
} 
In addition to the secondary literature outlined above, this thesis will make use of a several key archival resources. Records from the State Department housed at National Archives II in College Park, Maryland provide most of the information United States officials generated and thus the primary source for American perspectives on British Guiana and later Guyana. Additional United States governmental documents are incorporated from the Foreign Relations of the United States (FRUS) volumes concerning British Guiana from 1961-63 and volume XXXII Dominican Republic, Cuba, Haiti, Guiana 1964-68. The FRUS volumes are particularly valuable in their ability to fill in the gaps despite the considerable number of documents between high level American officials still classified in the State Department records. Memorandums from the United States Consulate in Georgetown to the State Department as well as from other posts in the Caribbean have yielded revealing insight on the evolution of the United States attitudes toward Forbes Burnham, especially from American officials in the region. Equally useful are memorandums from upper-level United States administrative officials and high ranking members of Great Britain’s Foreign Office. Diplomatic exchanges between senior officials in Whitehall and Washington will be used to determine how United States and British leaders conceived of their strategic concerns on the ultimate strategy pursued in British Guiana.

The major sources for understanding British perspectives and strategy will be based on Parliamentary records, records of the Foreign Office and the Colonial Office, and Cabinet Minute Papers housed at the British National Archives. This project will consider the varying agendas of the different institutional components of British government and how collective decisions were made as well as the interplay between the White House and British Parliament. As in the United States, memoranda and letters between various government posts reveal that there was a persistent evaluation and re-evaluation of potential leaders in British Guiana. These 
sources suggest that officials were engaged in an evolving assessment of Burnham and Jagan and search consistently for a third alternative to lead British Guiana to independence. When compared with U. S. State Department Records, a picture emerges which makes clear the complexity of Anglo-American cooperation in British Guiana. The significance of cooperation between Whitehall and Washington is considered at length by a number of important British officials whose conversations are accessible through these archives.

\section{Conclusion}

Nearly twenty years have passed since the end of the Cold War, and with time a more nuanced historical perspective is beginning to develop. Historians have concluded that histories of the Cold War that focus exclusively on great-power cooperation and conflict do not present a complete story of the Cold War. To obtain a more accurate view of how the Cold War unfolded, it is necessary to examine the agency of political actors who were not leaders of the great powers, including nationalist leaders in the developing world. The early 1960's represented the height of the Cold War as well as the climax of the long process of global decolonization. The complex relationship between these two phenomena is evident in the degree to which British Guiana presented a unique and crucial challenge to the Anglo-American cooperation which continued after the Second World War.

Events in Cuba throughout the 1960s resulted in a focused Cold War lens through which the United States contextualized international affairs. Realistic fears existed in regard to instability and communist infiltration in the Caribbean at the exact moment Great Britain sought to withdraw from the region. British fears of civil war and instability in their former colony were well founded. Such a scenario was likely to have occurred if the decolonization process was not 
carefully attended to. The potential for regional instability demanded a coordination of policy between Great Britain and the United States. The difficulties of collaboration are evident as the decolonization process is examined.

Ultimately, Guyana provides an excellent example of how Great Britain and the United States overcame their differences in individual strategic goals and coordinated a Cold War strategy for decolonization. As such, the process in which the country became the independent nation of Guyana is an insightful snapshot of the dual actions of both decolonization and Cold War reality and how they affected one another. Additionally, and perhaps most crucially, British Guiana presents an opportunity to acknowledge that while the United States drove Western Cold War policy, American leaders could not ignore events or political leaders in the developing world. Nationalist leaders in former colonies struggled to assert themselves in a newly restructured world and they too were forced to comprehend and work successfully within the framework established by the dual dynamics of the Cold War and decolonization. Nationalist leaders contributed immensely to the trajectory of the Cold War. It is outrageous that nationalist leaders in the developing world were forced to consider the imperatives of great powers or risk intervention; however, it is significant to consider the ways in which nationalist leaders influenced superpower policy. The actions of men like Cheddi Jagan and Forbes Burnham influenced to a significant degree they way the great powers of the era pursued the Cold War. This project, therefore, will examine the complex decolonization process in British Guiana in light of the power struggle between nationalist leaders, the United States and Great Britain during the Cold War. 


\section{Chapter 2: The Impact of Colonial History on the Decolonization Process in British Guiana}

On May 26, 1966 the largest empire in world history granted independence to its only colony on the South American mainland, the small enclave of British Guiana. The colony, known after independence as Guyana, has experienced negligible population growth since its independence forty-four years ago. Comparatively, it would be the sixtieth largest metro area in the United States in 2009, slightly edging out Syracuse, New York. ${ }^{1}$ Guyana encompasses roughly 83,000 square miles, about the same as Utah or Idaho, although the vast majority of the population is concentrated on a thin coastal plain. ${ }^{2}$ Notwithstanding the diminutive size of the territory in respect to land area and population, British Guiana held a vast significance for Great Britain and the United States from 1953 to 1966 as the colony struggled to establish a viable internal government and become an independent nation. Cold War geo-strategic concerns, the liquidation of the British Empire, and chaos within the colony all contributed to a decade and a half of intense concern, contention, and cooperation within the Anglo-American alliance.

This chapter will provide a general narrative history of British Guiana as an introduction to a more involved study of the decolonization and independence process in the colony from 1953 to1966. It will introduce a number of important themes, such as union-based politics, racial discord, and Anglo-American intervention, which will be further developed in subsequent chapters and explain how colonization created the societal characteristics which framed decolonization in British Guiana. Politics in British Guiana in the late colonial period was intricately connected to organized labor unions. These unions were formed as a result of relationships fostered in worker movements during episodes of economic crisis, specifically in

\footnotetext{
${ }^{1}$ CIA World Factbook, www.cia.gov/library/publications/the -world-factbook/rankorder/2119rank.html, www.census.gov/population/www/cen2000/briefs/phc-t3/tables/tab03.

${ }^{2}$ CIA World Factbook, www.cia.gov/library/publications/the-world-factbook/rankorder/2147/rank.html.
} 
the 1930s. Popular labor movements were a necessary outgrowth of colonial social structures which limited suffrage and forced the majority of the population to seek political voice through means other than a democratic vote. The liberal nature of international labor movements in the 1920s and 1930s left a permanent impression on Guianese political leaders seeking selfgovernment. Similar peculiarities of colonial society impacted race relations, international affairs, and economic development. These themes will be developed in this chronology of Guianese history in such a manner that they can be properly understood when drawn upon in subsequent chapters of this work.

The road to autonomous government in British Guiana was marred by a legacy of violence and racial conflict, often described as a phenomenon which "enflamed” the colony. Fire is literally and figuratively a fitting analogy for the events which preceded the establishment of an autonomous government in the colony. Literally, arson played a prominent role in the racial warfare which poisoned Georgetown and razed East Indian villages in 1962, 1963, and $1964 .^{3}$ Fire is even more useful as a metaphor to explain the eventual strife which plagued British Guiana. Three elements are necessary for a fire to burn: fuel, heat, and an igniter. British Guiana’s colonial history provided 130 years of tension between Afro-Guianese and East Indians. Colonial structures compounded antagonisms between the two largest ethnic groups in the colony and provided ample fuel for conflict. A small, but prominent upper-middle class of white merchants only added to the explosive mix of ethnic rivalry in the colony. Geo-strategic Cold War imperatives framed the Anglo-American perspective on how decolonization would occur in the British West Indies. The result was an increasingly rigid structure within which

\footnotetext{
${ }^{3}$ Cheddi Jagan, The West On Trial: My Fight For Guyana's Freedom (New York: International Publishers, 1966), 263-265; 357. Thomas Spinner, Political and Social History of Guyana 1945-83 (Boulder: Westview Press, 1984), 98; 100-105; Rabe, U.S. Intervention in British Guiana: A Cold War Story (Chapel Hill: The University of North Carolina Press, 2005), 110-112, 126.
} 
Guianese were forced to work. Outside influences heated up an already tense situation in the British Guiana. The ultimate catalyst which ignited the flames of racial warfare came from the politically opportunistic leadership of key Guianese nationalist leaders, especially Cheddi jagan and Forbes Burnham. Those politicians spoke to embedded fears warning that cultural subjugation would be the consequence if either ethnic group lost the election. The evolution of Guianese society made for a volatile situation as the colony prepared for self-government. This chapter will survey the historical background which led up to this volatile situation.

\section{Initial European Colonization and the Development of a Sugar Economy}

The early history of Guyana, like most European colonies in the Caribbean, was defined by two main characteristics: sugar and African slaves. ${ }^{4}$ Most of the area which today comprises the nation of Guyana was initially settled in 1621 by the Dutch West India Company. The Dutch established small colonies primarily located along the coastal belt, about three or four miles from the sea. ${ }^{5}$ Less than one hundred Europeans populated the Essequibo colony at the beginning of the eighteenth-century, and the population remained consistent until the West India Company opened the region to British settlers in the middle of the eighteenth-century. The population surged upward as British planters from neighboring Caribbean islands immigrated to the region during the last half of the eighteenth-century in search of fertile soils. ${ }^{6}$ Between 1781 and 1803 European wars shifted control of the colony between The Netherlands, Great Britain, and France. In 1803 Great Britain established rule over the colony permanently and that authority was

\footnotetext{
${ }^{4}$ Many scholars have discussed the influence of a sugar based economic system and the trans-Atlantic slave trade in terms of its developmental influence on the Caribbean. See: Robert J. Alexander, A History of Organized Labor in the English -Speaking West Indies (Westport, CT: Praeger, 2004), 327-328; Leo A. Despres, Cultural Pluralism and Nationalist Politics in British Guiana (Chicago: Rand McNally and Company, 1967), 3-4; Franklin W. Knight \& Colin A. Palmer, The Modern Caribbean (Chapel Hill: The University of North Carolina Press, 1989), 6-9.

${ }^{5}$ Spinner, Political and Social History of Guyana, 3-4.

${ }^{6}$ Rabe, U.S. Intervention in British Guiana, 15.
} 
ratified at the Treaty of Vienna in 1815. In 1831 the British unified their holdings in the region as the colony of British Guiana in the geographical structure that it holds today. ${ }^{7}$

Colonial Guianese society was dominated by a sugar plantation based economic system throughout the nineteenth-century. The labor intensive cash crop was the catalyst for the influx of racially diverse workers during the period. Initially the British found their primary source of labor in African slaves; however, the reformation of slave laws in the British Empire during the early to mid nineteenth-century, and subsequent abolition of slavery and the apprenticeship system in the 1830s, created a demand for alternative sources of low-cost labor. The majority of freed slaves in British Guiana refused to become wage laborers working for their former masters and migrated to the towns and villages, gradually becoming an urban proletariat. ${ }^{8}$ It was under these transformational circumstances that British planters sought salvation from their labor shortage problem. The planters' deliverance came with the importation of multitudes of indentured servants from across the globe. Immigrant laborers, in theory would work for an agreed upon number of years, usually five. ${ }^{9}$ However, wealthy planters strong armed workers, manipulated colonial laws, and benefited from lax application of Colonial Office trusteeship over servants. As a result, most indentures found themselves bound to plantations in slave-like conditions after their period of servitude expired. ${ }^{10}$ The majority of indentured workers were migrants from Britain’s jewel colony, India, and smaller numbers of indentured workers immigrated from Portugal and China as well, transforming the colony into an enclave of eclectic cultures on the mainland of South America. ${ }^{11}$ About 30,000 Portuguese immigrated to the

\footnotetext{
${ }^{7}$ Alexander, A History of Organized Labor in the English -Speaking West Indies, 327; Rabe, U.S. Intervention in British Guiana, 15; Spinner, Political and Social History of Guyana, 5.

${ }^{8}$ Spinner, Political and Social History of Guyana, 6.

${ }^{9}$ Ibid, 6.

${ }^{10}$ Saunders, Indentured Labour in the British Empire, 44-45.

${ }^{11}$ Rabe, U.S. Intervention in British Guiana, 16-20; Spinner, Political and Social History of Guyana, 6-8.
} 
colony, most arriving between the abolition of apprenticeship in 1838 and 1860. Chinese workers numbered about 14,000 and entered the colony primarily from 1850-1870. In addition, about 240,000 East Indians were imported into British Guiana between1838 and $1917 .{ }^{12}$ The sugar plantation system turned the colony into a monocrop economy that was hard to diversify once sugar prices collapsed. Additionally, the system of indentured servitude framed immigration to the colony and the demographic segregation of Guianese society along ethnic lines.

\section{Immigration and Social Development}

The early development of the colony established the basis for its social evolution during the ensuing century and into the independence period. Indentured servitude provided the impetus for multi-cultural immigration but did not create an integrated society. Workers received passage to British Guiana in exchange for an agreement to work for five years, primarily on one of the colony's sugar plantations. Indentures had the option to obtain an industrial residence upon the expiration of required service until 1862 when the Court of Policy established reindenture for a period of five years to quell competition with the free labor market. Immigrant laborers were virtually imprisoned on the estates to which they were bound as a result of such modifications to colonial policy. High levels of immigration continued until the combination of a numerically significant labor force and the world sugar crisis of 1894-95 decreased the need for additional cheap labor in the colony. By the mid-1890s there were enough poor laborers in British Guiana for planters to establish a system of cheap wage labor, thus ending the indenture system in the colony. ${ }^{13}$ East Indians’ desire to retain cultural traditions and their economic dependence on

\footnotetext{
${ }^{12}$ Spinner, Political and Social History of Guyana, 6-7.

${ }^{13}$ Kay Saunders, ed. Indentured Labour in the British Empire 1834-1920 (London: Croom Helm Ltd., 1984), 45-46.
} 
plantation owners left them isolated from the rest of Guianese society. The structural isolation of East Indian indentures was the first of several examples of colonial systems segregating the ethnic communities of the British Guiana.

Despite racial and cultural diversity, immigrant groups formed communities based on ethnic affiliation and employment was organized along racial lines. The majority of Portuguese and Chinese workers moved into towns and villages to pursue retail trades upon the completion of their period of servitude and the Chinese especially assimilated well into the existing European culture of the urban areas. The Portuguese community suffered through periods of antagonism from other cultural groups because of their Roman-Catholic heritage. Additionally, the indebted lower classes occasionally blamed Portuguese retailers for price hikes during periods of economic stagnation, leading to anti-Portuguese riots in 1856, 1889, and $1905 .{ }^{14}$ The majority of the East Indian population in British Guiana, however, remained based in rural areas hoping to preserve cultural traditions and become independent land owners through rice cultivation. ${ }^{15}$

The two largest ethnic groups were those of African and East Indian origin. AfroGuianese and East Indians developed quite separate cultures despite the limited geographical size of the colony and its few population centers. In addition to the system of indenture, cultural exchange was limited by other colonial structures, specifically the colonial educational system. Great Britain mandated compulsory education for the Guianese in 1876 based on Christian run schools. Consequently, there was virtually no enforcement of the law in regards to East Indians, who resided predominantly on sugar estates and developed a segregated society based on

\footnotetext{
${ }^{14}$ Spinner, Political and Social History of Guyana, 7.

${ }^{15}$ Ibid, 7-9.
} 
traditional Hindu or Muslim cultures. Therefore, the Afro-Guianese population established an urban based culture centered on education, Christian religion, and a moderate conformity to British norms and values. In contrast, East Indians resided principally in rural areas where they worked in sugar fields and after 1900 began cultivating rice. Many East Indians obtained small amounts of Crown land from settlement schemes designed to entice them to remain in the colony after their period of servitude expired, while others remained as wage workers on large sugar plantations. ${ }^{16}$ Lack of education, and strong familial ties, limited the ability of East Indians to migrate to urban areas. ${ }^{17}$ Other structural characteristics of the British colonial system worked in conjunction with the educational laws to further develop what has frequently been defined as a pluralistic society. ${ }^{18}$ The mining industry, for example, existed outside the spectrum of indentured labor, drawing its workers from the displaced Afro-Guianese community. A considerable number of former slaves became prospectors, or worked as laborers for the small industry of the colony. These individuals were paid in cities and, despite working in the interior, congregated in towns and villages, slowly acquiring small pieces of property and establishing a unique urban culture. ${ }^{19}$ British Guiana's racial demographics and its occupational and social segregation framed the colony's political evolution. East Indians were disenfranchised for most of the colony's history, despite being the largest ethnic group in British Guiana and the East Indian community was fiercely loyal to Cheddi Jagan when he emerged a political leader. ${ }^{20}$ Additionally, occupational segregation meant that the pursuit of a political agenda directed at improving conditions for field workers or urban laborers inherently resulted in alignment with a specific ethnic group.

\footnotetext{
${ }^{16}$ Despres, Cultural Pluralism and Nationalist Politics in British Guiana, 60-62.

${ }^{17}$ Ibid, 51-52, 59.

${ }^{18}$ A brief explanation of the concept of cultural pluralism is provided in the introduction.

${ }^{19}$ Ibid, 52-53.

${ }^{20}$ Horne, Cold War in a Hot Zone, 17.
} 
Despite the development of several distinct ethnic cultures, racial conflict in British Guiana was less violently pervasive than in other culturally diverse societies, such as the United States. Open interracial conflict was uncommon in the colony, though as mentioned, there were persistent antagonisms in Guianese society, which occasionally surfaced in episodes such as the anti-Portuguese riots and intermittent Afro-Guianese-East Indian violence. Cultural rivalry was manifested in intense disdain between the Afro-Guianese and East-Indian communities and struggle was endemic, though generally non-violent prior to the independence period. ${ }^{21}$ The segregated nature of Guianese society may have acted as a veil through which passionate ethnic rivalry was obscured by structural separation. Self-government demanded a more integrated society and Guianese leaders increasingly exploited racial issues for political advantage as the colony neared independence.

\section{Venezuelan Boarder Dispute}

International conflicts during the colonial period also contributed to the complexity of the independence process in British Guiana. Transfers of European rule in British Guiana during the eighteenth century resulted in confusion over the ill defined regional borders. In 1895 a long standing Venezuelan territorial claim of the Essequibo region threatened to erupt into a full-scale international crisis when the United States moved to support the Venezuelan position as a means of affirming its own growing influence in the Caribbean. Great Britain asserted its right to the region based on Dutch secession of the territory in the Treaty of Vienna in 1815.The Essequibo region was meagerly inhabited; but it comprised nearly two-thirds of British Guiana and was believed at the time to be rich in a plethora of minerals; specifically, gold, copper, and iron-ore,

\footnotetext{
${ }^{21}$ Knight \& Palmer, The Modern Caribbean, 96-97.
} 
as well as potentially containing coastal oil deposits. ${ }^{22}$ Venezuela and Great Britain agreed to submit to international arbitration and the United States appointed a committee to resolve the matter. The council appointed to decide the matter was composed two judges from the United States and two from Great Britain and was presided over by a representative from Russia. ${ }^{23}$ The decision strongly favored Great Britain, making the entire ordeal appear to have been a political play by the United States. Venezuela received Point Barima, the Orinoco River mouth, and 3,000 miles in the interior while Great Britain was awarded 50,000 square miles of the territory when the decision was handed down. ${ }^{24}$ The Venezuelan congress was unsatisfied with the arbitration and despite the fact that they accepted the commission's findings in 1905; intermittent diplomatic protests were voiced in Caracas over the ensuing half-century, culminating in a Special Political Committee in the United Nations in $1962 .{ }^{25}$ The diplomatic instability resulting from the dispute would have implications for British Guiana's independence during the 1960s and eventually led to armed conflict after Guyana’s independence. ${ }^{26}$

\section{Colonial Economics in the Early Twentieth Century}

British Guiana’s economic development contributed significantly to its social and political evolution. By the early twentieth century, a disproportionate amount of influence in British Guiana was held in the hands of a small number of large western companies. The First World War served as the catalyst for the investment of American and Canadian companies in the bauxite mining industry in the British West Indian colonies, primarily British Guiana and Jamaica. The interests of these companies became crucial during the Second World War and

\footnotetext{
${ }^{22}$ Jacqueline Anne Braveboy-Wagner, The Venezuela-Guyana Border Dispute: Britain's Colonial Legacy in Latin America (Boulder: Westview Press, 1984), 77-80.

${ }^{23}$ Spinner, Political and Social History of Guyana, 13-14.

${ }^{24}$ Wagner, The Venezuela-Guyana Border Dispute, 106.

${ }^{25}$ Ibid, 107-109.

${ }^{26}$ Ibid, 150-165.
} 
their importance grew further with the increasing tension of the Cold War in the 1950s. The Truman Administration passed NSC-68 in 1950, outlining a new, aggressive American strategy for conducting the Cold War and bauxite, the mineral used to make aluminum, was an essential component of the American military buildup. Additionally, the onset of the Korean War in 1950 further increased the American demand for aluminum. ${ }^{27}$ The Demerara Bauxite Company of Canada and Reynolds Metals Company, based in the United States, controlled almost all of the bauxite industry in British Guiana.

The most influential capital investor in British Guiana was Booker Brother’s McConnell and Company Limited, a British company which established a virtual monopoly on sugar and plantations, controlling almost eighty-five percent of the arable land in the colony. ${ }^{28}$ Bookers’ influence was not confined to plantations. The company also operated one of the largest mercantile enterprises in the colony, including drug stores, shipping lines, manufacturing companies, and subsidiaries in shrimping, printing, stock feeds, insurance, and distilleries. ${ }^{29}$ In his work, Cold War in a Hot Zone, Gerald Horne notes that Booker Brothers wielded such an influence in the colony that future Guianese Prime Minister Cheddi Jagan once stated: “[Bookers] are and indeed always have been the real rulers of our country." 30 Stephen Rabe notes that many Guianese made light of the situation by referring to the colony as “Booker’s Guiana”. By 1962 Bookers was the primary source of income for 100,000 people, almost a fifth

\footnotetext{
${ }^{27}$ Jason Parker, Brother's Keeper: The United States, Race, and Empire in the British Caribbean, 1937-1962 (Oxford: Oxford University Press, 2008), 84-86.

${ }^{28}$ James L. McDonald, “Overriding Interests: Subversion as an Instrument of U.S. Foreign Policy” (Ph.D. diss., American University, 1997), 365; Rabe, 20-21; Spinner, 10-11.

${ }^{29}$ Alexander, A History of Organized Labor in the English -Speaking West Indies, 328-329.

${ }^{30}$ Daily Gleaner (Jamaica), 11 October, 1945 Cited in Gerald Horne, Cold War in a Hot Zone: The United States Confronts Labor and Independence Struggles in the British West Indies (Philadelphia: Temple University Press, 2007), 163.
} 
of the population. ${ }^{31}$ The global economic crisis in 1894-95, and again in the 1930s, led to a decline in sugar prices and a subsequent increase in the importance of rice and bauxite to British Guiana. However, the diversity of Bookers' investments ensured the company's prominence in the colony into the independence period. The economic monoculture and social segregation fermented in British Guiana from 1815-1950 helped frame the independence process from 19501966.

\section{Organized Labor and Political Evolution}

Social conditions in British Guiana severely restricted political involvement in the colony and led to the rise of organized labor as the primary conduit for political voice as was characteristic of most of the British Caribbean. Thus, the intricacies of workers' movements defined the trajectory of political development in the colony. Property requirements limited the voting population to a miniscule 4,300 individuals in 1915. Additionally, suffrage was entirely disproportionate to population demographics. Sixty percent of registered voters were AfroGuianese, twenty percent British, eleven percent Portuguese, and only six percent East Indian; despite the fact that East Indians comprised roughly fifty percent of the adult male population. ${ }^{32}$ As a result, disenfranchised workers attempted to gain a political voice through collective labor movements. Several attempts were made at collective labor movements in the colony to combat wartime inflation without success during the 1910s. Hubert Nathaniel Critchlow, an AfroGuianese dock worker, established the first permanent labor union, the British Guiana Labour Union (BGLU) in 1919 with the assistance of British union leaders. ${ }^{33}$ Critchlow organized the "First British Guiana and West Indies Labour Conference” in Georgetown in 1926. The

\footnotetext{
${ }^{31}$ Rabe, U.S. Intervention in British Guiana, 21.

${ }^{32}$ Spinner, Political and Social History of Guyana, 10.

${ }^{33}$ Alexander, A History of Organized Labor in the English -Speaking West Indies, 339-340.
} 
conference resulted in the formation of the British Guiana and West Indian Labour Federation, the first regional labor movement. Critchlow's socialist leanings laid the foundation for the strong connection between liberal ideals and labor unions, characteristics which defined British Guianese politics for the next forty years. It is pertinent to note the animosity Critchlow had for the East Indian community as well as the reality that union based politics contributed to further racial polarization in Guianese society. Gerald Horne accurately draws a connection between the marginalization of the East Indian community and the rise of Cheddi Jagan twenty years later. ${ }^{34}$

Global economic depression during the 1930s was the impetus for the most significant changes in British Guiana during the mid-twentieth century. Sugar prices fell drastically resulting in extreme unemployment and decreased wages for already desperately poor field workers. Labor unrest increased toward the middle of the decade and climaxed in October 1935 when sugar workers walked off of several estates in the colony's Demerara and Berbice districts. Striking workers had difficulty obtaining concessions from their employers, however, due to a lack of effective organization. ${ }^{35}$ Thus, the establishment of the Manpower Citizen’s Association (MPCA) in 1936 was a critical development in the political evolution of the colony. The organization came to be the most powerful representation of sugar workers in British Guiana during the independence period. ${ }^{36}$ Cheddi Jagan worked with the MPCA early in his political career; however, by the late 1940s Jagan determined that MPCA leaders were loyal to Bookers, rather than the field workers. Jagan began organizing opposition to the MPCA and he helped to establish the Guiana Industrial Workers Union (GIWU) as an alternative union for sugar workers. His measures against the union were the catalyst for some of the most intense violence

\footnotetext{
${ }^{34}$ Horne, Cold War in a Hot Zone, 15-17.

${ }^{35}$ Alexander, A History of Organized Labor in the English -Speaking West Indies, 346-348.

${ }^{36}$ Horne, Cold War in a Hot Zone, 75, Rabe, U.S. Intervention in British Guiana, 21.
} 
and unrest in the colony during the independence period. ${ }^{37}$ In response to increased political organization, the British Colonial Office relaxed voting laws during the 1930s, extending suffrage to a few thousand additional colonists. ${ }^{38}$

\section{Consequences of the Great Depression and World War II on Colonial Development}

The effects of the Great Depression continued to impact the Caribbean forcefully in 1937-38. Consistently decreasing prices of rice, sugar, and bauxite during the decade culminated in extensive unemployment in the region by the end of the 1930 s. ${ }^{39}$ Caribbean labor organizations hosted demonstrations in an attempt to improve the situation in the British West Indies, while organized workers reacted violently as labor unrest shook Trinidad in May 1938. Repercussions were felt across the British West Indies and beyond. Great Britain passed the Colonial Development and Welfare Act of 1940 in large part because of the consequences of the economic crisis in the Caribbean during the 1930s. Colonial administrators in Great Britain feared that protests against poor wages, terrible working conditions, and inadequate housing would spread to British Guiana and Jamaica through the increasingly interconnected network of trade unions. In response, the government sent a commission headed by Lord Moyne to the region in $1938 .^{40}$ The Moyne Commission found terrible conditions including a serious lack of educational opportunity, deep poverty, and a rapidly increasing population in the region. The commission advocated serious economic and social reforms, such as increasing sugar subsidies and diversifying the economies of the region, as well as an expansion of suffrage for the colonies. Jason Parker notes crucially that while the importance of political reform was noted,

\footnotetext{
${ }^{37}$ Horne, Cold War in a Hot Zone, 163, 183; Rabe, U.S. Intervention in British Guiana, 37-38, 110.

${ }^{38}$ Rabe, U.S. Intervention in British Guiana, 21.

${ }^{39}$ Spinner, Political and Social History of Guyana, 11.

${ }^{40}$ Horne, Cold War in a Hot Zone, 32; Spinner, Political and Social History of Guyana, 11.
} 
the British government made few concessions to the internal governments of the region. ${ }^{41}$ Despite the intentions of the commission, the outbreak of World War II made investment in the colonies and attempts at reform impossible for Great Britain for nearly a decade.

World War II also affected the region by drastically increasing the presence of the United States in British colonies. In 1940 Great Britain and the United States concluded the Destroyers for Bases Deal, assuring an amplified United States military presence in the region and in November of that year Franklin Roosevelt sent Charles Taussig to the Caribbean to survey the region. Taussig drew conclusions similar to those of Lord Moyne; deciding that overpopulation, disproportionate economic conditions, racial issues, and an abysmal infrastructure made the region susceptible to pro-Berlin forces. ${ }^{42}$ It is pertinent to note Taussig's conclusion that the region was ripe for subversion simultaneously with his identification of active socialist labor movements in the region. The end of World War II did not result in an easing of American apprehension about security issues in the Caribbean. United States policymakers increasingly feared communist subversion in the region as the Cold War grew more intense. The conclusions drawn by the Taussig Commission actually became more relevant twenty years after the study.

In 1942 the United States constructed Atkinson Airfield in British Guiana as part of the Destroyer for Bases Deal. ${ }^{43}$ The presence of a modern airfield on the South American continent and the Caribbean rim had implications which far exceeded its purpose during the Second World War, despite the fact that the base was closed after the Japanese surrender. ${ }^{44}$ British Guiana came

\footnotetext{
${ }^{41}$ Parker, Brother's Keeper, 22-24; Rabe, U.S. Intervention in British Guiana, 21-22.

${ }^{42}$ Horne, Cold War in a Hot Zone, 42-43.

43 Ibid, 52; Rabe, U.S. Intervention in British Guiana, 22; Spinner, Political and Social History of Guyana, 13.

${ }^{44}$ Rabe, U.S. Intervention in British Guiana, 32.
} 
to take on a critical role in Anglo-American geo-strategy as the Cold War took the place of World War II as the primary Western security concern.

\section{Post-War Political Development}

During the early 1940s, British Guiana continued to make slow political progress as the general population became more actively involved in organized labor unions. In 1943 the constitution was liberalized decreasing the property qualifications for officeholders and further increasing the number of qualified voters in the colony. Also in 1943, the East-Indian Cheddi Jagan returned to British Guiana along with his newlywed American wife, the former Janet Rosenburg, after finishing dental school in the United States. ${ }^{45}$ The Jagans quickly became a political force in British Guiana and irreversibly altered the trajectory of the colony's political history. Like most East-Indians in British Guiana, Jagan grew up on a sugar estate where his father worked as a cane-cutter and eventually foreman of a sugar gang. ${ }^{46}$ Cheddi Jagan had lived in the United States since 1936 when he left his home to attend Howard University with his entire family’s savings of $\$ 500 .{ }^{47}$ Jagan had begun to develop strong political views by the time he returned to the colony, and in 1945 he was sent as British Guiana’s representative to the newly founded Caribbean Labour Congress. ${ }^{48}$ In 1946 Cheddi and Janet Jagan formed the Political Affairs Committee (PAC) with the help of the Afro-Guianese trade unionist Ashton Chase and H.J.M. Hubbard, a white Marxist. ${ }^{49}$ Jagan won a seat on the colony’s legislative council in 1947 after the Colonial Office eased voting requirements increasing the electorate to 60,000. The support of Sidney King, an Afro-Guianese school teacher, was crucial to his victory.

\footnotetext{
${ }^{45}$ Spinner, Political and Social History of Guyana, 13-14.

${ }^{46}$ Jagan, The West on Trial, 15-18.

${ }^{47}$ Ibid, 47.

${ }^{48}$ Horne, Cold War in a Hot Zone, 62-64.

${ }^{49}$ Spinner, Political and Social History of Guyana, 24.
} 
Janet Jagan and Hubbard unsuccessfully campaigned for seats on the council. ${ }^{50}$ The PAC attempted to draw from this victory a multi-racial support base to advance an agenda of selfgovernment and universal adult suffrage. ${ }^{51}$

The PAC was strengthened by its response to labor unrest in the colony in 1948. By the mid-1940s, the leadership of the MPCA had become corrupted by the interests of Bookers Brothers and ceased working for the wellbeing of the field workers. Membership dropped from 20,000 in 1940 to 5,000 in $1948 .^{52}$ There were two primary reasons for the disillusionment of workers. The first was that the union permitted Bookers to censor the material in the union periodical. The second was that the union's expenses were almost entirely covered by advertisements by Bookers. ${ }^{53}$ The diminishing influence of the MPCA created a vacuum which allowed for the emergence of the GIWU, which pursued a more active role attempting to gain concessions from large sugar cooperatives. ${ }^{54}$ Throughout the spring, sugar workers organized a strike incorporating all of the sugar estates on the East Coast of Demerara. Five striking workers on the Enmore Sugar Estate were killed and another fourteen wounded by police on June 16. The Jagans responded by organizing a mass march for workers rights. ${ }^{55}$ The members of the PAC also began to work on the organization of a political party which they modeled on the Progressive Party in the United States and Norman Manley’s People’s National Party in Jamaica.

\footnotetext{
${ }^{50}$ Ibid, 25Rabe, U.S. Intervention in British Guiana, 27.

${ }^{51}$ Spinner, Political and Social History of Guyana, 24.

${ }^{52}$ Alexander, A History of Organized Labor in the English -Speaking West Indies, 348, 365.

53 Ibid, 358.

${ }^{54}$ Ibid, 354.

${ }^{55}$ Horne, Cold War in a Hot Zone, 163; Rabe, U.S. Intervention in British Guiana, 27; Spinner, Political and Social History of Guyana, 27.
} 
Cheddi Jagan strengthened his political ties in 1949 when he became head of the Sawmill Workers Union and most importantly when he met Lyndon Forbes Burnham. ${ }^{56}$ Like Jagan, the Afro-Guianese Burnham left the colony to obtain a higher education and graduated from the University of London in 1947 with a degree in law. During his time in England, Burnham worked closely with the Caribbean Labour Congress (CLC) in London and fostered ties with the Communist Party of Great Britain. Before returning to British Guiana in 1949 Burnham helped the League of Coloured Peoples organize demonstrations against racism in the colonies. ${ }^{57}$ Burnham set aside the strong sense of Afro-Guianese superiority for which he was known, and joined with the Jagans to form the People's Progressive Party (PPP) on January 1, $1950{ }^{58}$ The organizational structure of the PPP was impressively multi-racial considering the contentious history of race relations in British Guiana. Both Jagans held prominent positions; Cheddi as party leader and Janet as general secretary. Forbes Burnham was named party chairman and Sydney King became assistant secretary. Clinton Wong, of Chinese heritage, was named senior vicechairman. ${ }^{59}$

In Great Britain, Prime Minister Clement Atlee’s Labour Party began to advance a policy of guided decolonization throughout the British Empire, progressively granting internal selfgovernment to its colonies to in preparation for independence. In 1950 sent a commission to British Guiana headed by Dr. E.J. Waddington to assess the state of the colony. The Colonial Office was concerned about the residual effects of the violence in 1948 as well as the social and economic issues identified by the Moyne Commission. The Waddington Commission's recommendations to the Colonial Office led to important changes in the political structure of

\footnotetext{
${ }^{56}$ Horne, Cold War in a Hot Zone, 163.

${ }^{57}$ Ibid, 164; Rabe, U.S. Intervention in British Guiana, 22-23.

${ }^{58}$ Rabe, U.S. Intervention in British Guiana 27.

${ }^{59}$ Spinner, Political and Social History of Guyana, 29-30.
} 
British Guiana. Universal adult suffrage was extended to the population of the colony, eliminating previous property and income restrictions in place in 1950. Additionally, a lower House of Assembly comprised of elected Guianese was added to the colonial legislature within the colony. The majority of the Executive Council of the colony would be drawn from the House of Assembly; however, the colonial governor retained veto powers over the colony as well as the authority to certify elections. ${ }^{60}$

By 1952 Cheddi and Janet Jagan’s political ideology was becoming a point of concern for administrators in both Great Britain and the United States as well as within the colonial governments of the British West Indies. A British report on the PPP in late 1951 noted the party's alignment with the CLC and labeled it a socialist party. Consequently, colonial authorities increasingly restricted the Jagans' movement throughout the region between 1948 and 1952. ${ }^{61}$ Trade unions in the United States with strong connections to the American government, such as the American Federation of Labor (AFL), Congress of Industrial Organization (CIO), and Inter-American Regional Organization (ORIT), labeled the Jagans communists in 1951. Jay Lovestone, Secretary-treasurer of the AFL, made the crucial determination that although the Jagans were communists, elements within the PPP were not so ideologically inclined and included Burnham in the second group after sanctioning a fact-finding mission on the situation to British Guiana. That information was passed on to the State Department in Washington D.C. ${ }^{62}$ The anti-communist organized labor front in the United States became a conduit for the

\footnotetext{
${ }^{60}$ Rabe, U.S. Intervention in British Guiana, 31-32; Spinner, Political and Social History of Guyana, 31-34.

${ }^{61}$ Horne, Cold War in a Hot Zone, 167-171.

${ }^{62}$ Stephen Rabe and Gordon Oliver Daniels offer thorough explanations of the ties between Lovestone, the AFL$\mathrm{CIO}$ and the White House. They also detail the close relationship between the most prominent organized labor unions in the United States and the Central Intelligence Agency (CIA). Those relationships are outside the scope of this thesis; however, it is pertinent to note their existence in order to substantiate the relevance of Lovestone's evaluation. See: Rabe, U.S. Intervention in British Guiana, 37-38; Gordon Oliver Daniels, "A Great Injustice to Cheddi Jagan: The Kennedy Administration and British Guiana, 1961-63” (Ph.D. Diss., University of Mississippi, 2000).
} 
American acquisition of intelligence on British Guiana, especially after the United States consulate was closed in $1953 .^{63}$

\section{Internal Self-Government and British Resumption of Direct Rule}

In April 1953 British Guiana embarked on what seemed to be the beginning of a transition to independence when Great Britain oversaw the first national election in Guianese history. ${ }^{64}$ The results of the election, and the consequences which resulted from the actions of the PPP in its aftermath, set the precedent for the independence process in the colony. The PPP won eighteen of twenty-four contested seats in a decisive victory that took the British by surprise. In an attempt to maintain racial solidarity the party sent three East Indians and three Afro-Guianese party members as its representatives to the governor's Executive Council. ${ }^{65}$ The Jagans moved to implement a number of social reforms in British Guiana in light of the overwhelming nature of their victory. The PPP targeted support for low-cost housing, workmen’s compensation, land reform, and public education. Scholars have generally interpreted the measures pursued by the PPP as relatively modest. However, British officials and contemporary political opposition, specifically members of the MPCA who were fearful of losing power under a Jagan-led government, interpreted Jagans moves as an attempt to consolidate support for the PPP and undermine his political opposition. The MPCA soon began to suggest that the Jagans were attempting to implement a communist government in the colony. ${ }^{66}$ The allegations grew when

\footnotetext{
${ }^{63}$ Rabe, U.S. Intervention in British Guiana, 33.

64 Ibid, 13.

${ }^{65}$ Ibid, 38.

${ }^{66}$ The National Archives, Kew, Richmond, Surrey (hereafter TNA), Colonial Office (hereafter CO) 1031/4405, Records of the West Indian Department, Note by Alec Douglas-Home, 19 November 1963. Some historians are skeptical of Jagan's contemporaries who saw communist undertones in the measures pursued by the PPP in 1953. See: Rabe, U.S. Intervention in British Guiana, 38-39. Others suggest a more nuanced argument detailing the political implications of Jagan's measures, perhaps suggesting that Jagan's motivation in pursuing such reforms was not without a specific political agenda beyond social improvement. See: Spinner, A Political and Social History of Guyana, 43-44.
} 
the PPP overturned the Undesirable Publications Act which banned subversive literature, creating a legal means for the PPP distribution of communist literature in the colony.

In September 1953 the GIWU called a nationwide sugar strike halting production of the colony's chief form of revenue ${ }^{67}$ Jagan hoped to use the strike to argue for the necessity of a Labour Relations Bill to expand workers rights by permitting laborers to certify unions of choice and decertify existing unions. If the bill was passed the PPP could use it as the legal structure for the GIWU to supplant the MPCA, diminish the power of Bookers in the colony, and consolidate support for the PPP among the sugar workers. ${ }^{68}$ Lionel Luckhoo, head of the MPCA and instigator of the previously overturned Undesirable Publications Act, was outraged. As a consequence of the attempted reform the colony became mired in open political warfare. ${ }^{69}$ British officials became increasingly concerned that the PPP was orchestrating a communist takeover and British troops landed on October 4 to establish order. The bill passed on October 8 and on October 9 Governor Alfred Savage suspended the constitution and took direct control of the colony. ${ }^{70}$ The main thrust of British opposition to the internal government was aimed at the Jagans. While the Colonial Office distrusted Forbes Burnham and other PPP leaders, no one in British Guiana was considered as much of a threat as Cheddi and Janet Jagan in 1953.

Sir James Robertson headed the British Parliamentary Commission sent to investigate the 1953 crisis in British Guiana. The Robertson Commission's conclusions were released in late 1954. The commission drew that same conclusion that the official Parliamentary report, or White Paper, had the previous year, determining that the PPP was comprised of a "very powerful

\footnotetext{
${ }^{67}$ Despres, Cultural Pluralism and Nationalist Politics in British Guiana, 208.

${ }^{68}$ Ibid, 207-208.

${ }^{69}$ Ibid, 205; Rabe, U.S. Intervention in British Guiana, 39.

${ }^{70}$ Rabe, U.S. Intervention in British Guiana, 42-43; Spinner, Political and Social History of Guyana, 43-46.
} 
communist element” lead by the Jagans. ${ }^{71}$ The commission also concluded that the Jagans “unreservedly accepted the classical communist doctrines of Marx and Lenin and were supporters of the most modern communist movements.” Meanwhile, Robertson classified Burnham as a moderate social democrat, opposed to British rule, but not communist. ${ }^{72}$ The commission placed the blame for the suspension of the constitution squarely on the PPP and did not set a timeframe for the restoration of self-government in the colony. Finally, the commission foresaw increasing racial confrontations as the growing East Indian population asserted control over the Afro-Guianese of the colony. ${ }^{73}$

The suspension of the constitution in 1953 set in motion a series of events that redefined the political scene in British Guiana. Governor Savage attempted to assert control in the colony by minimizing the influence of the Jagans. Cheddi Jagan was sentenced to six months of hard labor after violating a travel ban imposed on him and his wife by the Governor. Janet was imprisoned five months later for conducting a public meeting and being in possession of an illegal Police Riot Manual. Simultaneously, fissures began to develop within the PPP. Moderate party members thought Jagan's policies were responsible for the suspension of the constitution and attempted to redefine the party's ideological positions. Unable to reconcile their differences, the party split into competing and increasingly contentious camps. Jagan held together many of the traditional leaders of the party, crucially maintaining the support of the Afro-Guianese Ashton Chase, Sydney King and Martin Carter. Burnham fronted the opposition, a moderate

\footnotetext{
${ }^{71}$ Report of the British Guiana Constitutional Commission, Sir James Robertson, Chairman, Colonial Office (London: Her Majesty’s Stationary Office Report Cmd. 9274, 1954), Cited in Spinner, Political and Social History of Guyana, 56.

72 Report of the British Guiana Constitutional Commission, Sir James Robertson, Chairman, Colonial Office (London: Her Majesty’s Stationary Office Report Cmd. 9274, 1954), Cited in Despres, Cultural Pluralism and Nationalist Politics in British Guiana, 5.

${ }^{73}$ Rabe, U.S. Intervention in British Guiana, 52-54; Spinner, Political and Social History of Guyana, 56-58.
} 
group of politicians including Clinton Wong and the East Indian Jai Narine Singh. ${ }^{74}$ Jagan and Burnham understood the critical importance of maintaining a multi-racial base of support and worked tirelessly to win the approval of both East Indians and Afro-Guianese. Both men managed to retain multi-racial support initially, but that victory was short lived.

The PPP splintered further in late 1956. The swift and conclusive British response to reformatory policies in 1953 convinced Cheddi Jagan that it would be necessary to approach change within the colony more cautiously. He moderated his stance on several issues and was vaguely critical of the rhetoric of individuals in the party three years prior. His altered perspective, especially his decision not to pursue inclusion in the proposed West Indies Federation, alienated several key members of his faction of the PPP and ended his alliance with King and Carter. ${ }^{75}$ It is somewhat unclear whether Jagan expelled King and Carter upon the urging of the British or if they chose to leave the party on their own. Regardless of the circumstances, by the end of the year the political situation had degenerated into increasingly racially segregated party alliances.

\section{The Development of Racial Politics in British Guiana}

The United States returned its consulate to British Guiana in 1957 just as Great Britain was preparing to return partial sovereignty to the colony. The Colonial Office eliminated the restrictions placed on the Jagans upon the repeated suggestion of Governor Patrick Renison and prepared the colony for the elections to be held in August. Meanwhile, colonial politicians increasingly appealed to loyalty based on ethnicity. The PPP initially used the expression “Apan-

\footnotetext{
${ }^{74}$ Spinner, Political and Social History of Guyana, 59-64, 67.

75 Jennifer Dale Kibe, “Presidents as Kingmakers: U.S. Decisions to Overthrow Foreign Governments” (Ph.D. Diss., University of California Los Angeles, 2002), 281; Spinner, Political and Social History of Guyana, 68-70.
} 
Jhaat”, or vote for your own, in the East Indian community. ${ }^{76}$ Leo Despres explains that properly contextualized the expression encouraged cooperation between people of similar cultural values. The slogan did not have an explicit racial connotation in its initial manifestation; rather it was a means of identifying certain nationalistic ideals. However, it came to be understood by many within the Afro-Guianese community and especially British and American observers as an expression of divisive racial politics. ${ }^{77}$ Internal self-government returned to British Guiana in August 1957 with the PPP again dominating the elections, establishing Cheddi Jagan as the most viable political figure in the colony. In response, Forbes Burnham announced the formation of a new political party, the People’s National Congress (PNC) after the election, acknowledging Jagan’s leading role in the PPP. ${ }^{78}$

The increasingly racial aspect of politics in British Guiana has held a place of primacy in traditional explanations for the degeneration of the nationalist movement in the decade prior to independence. Scholars have shown that racial identification became increasingly connected with identification to specific political parties after the Jagan-Burnham split in 1955. However, Rishee Thakur postulates that ideological differences were the most significant factor in the schism in the PPP and the further fragmentation of the Guianese movement. ${ }^{79}$ He argues that the disintegration of the PPP in 1955 was a left-right split, based on the need to formulate a new political agenda after the suspension of the Constitution in 1953. The inability of the party

\footnotetext{
${ }^{76}$ Spinner, Political and Social History of Guyana, 72.

${ }^{77}$ Despres, Cultural Pluralism and Nationalist Politics in British Guiana, 229.

${ }^{78}$ Spinner, Political and Social History of Guyana, 73.

${ }^{79}$ Rishee Thakur takes issue with Despres and traditional cultural pluralists who subordinate the important role of political ideology among third world nationalists to simplistic cultural explanations. He contextualizes cultural pluralism as the Caribbean variant of Modernization Theory, essentially arguing that while cultural divisions existed in Guianese society, their ability to fragment the nationalist movement was significant only within the broader context of political/ideological differences within the movement itself. Thakur suggests that most of the racial violence was a manufactured product of political maneuvering by Jagan and Burnham and subversion efforts by the United States. See: Rishee S. Thakur, “Politics and Hegemony in Guianese Nationalism, 1945-1965” (Ph.D. Diss., York University, 1994).
} 
leaders to collaborate on a new strategy led to the split, followed by realignment of their supporters. ${ }^{80}$ Gordon Oliver Daniels suggests that Jagan pursued domestic policies which inherently benefited the East Indian community after the PPP victory in 1957. Daniels suggests that even if the policies were not racist in design, they were in effect. ${ }^{81}$ However, Thakur notes that irreconcilable racial differences within the nationalist movement were not evident until at least 1959, suggesting that racial tensions during the 1950s and 1960s were not predetermined. ${ }^{82}$

It is also pertinent to acknowledge the individual political rivalry between Jagan and Burnham and the debate over British Guiana's future participation ion in the proposed West Indies Federation. Both Jagan and Burnham had strong personalities and harbored intensions of being the father of Guyana. Their rivalry in itself contributed greatly to the schism in the party. ${ }^{83}$ Finally, increasing racial tensions were exacerbated by the debate over whether British Guiana would join the West Indies Federation. The Afro-Guianese community welcomed the opportunity to establish a closer relationship with the predominantly black Caribbean nations, such as Jamaica and Trinidad and Tobago. East Indian Guianese feared that association with the Caribbean nations would lead to migration of blacks to Guiana, and a marginalization of the East Indian community. ${ }^{84}$ Thus, as British Guiana neared independence, its two most important political leaders pursued opposing policies on the critical issue of alliance with the West Indies Federation, based on racial prerogatives and increasingly engaged in racial politics.

\footnotetext{
80 Ibid, 85-86.

${ }^{81}$ Daniels, “A Great Injustice to Cheddi Jagan”, 143.

82 Ibid, 378.

${ }^{83}$ Colin A. Palmer, Eric Williams and the Making of the Modern Caribbean (Chapel Hill: The University of North Carolina Press, 2006).

${ }^{84}$ Daniels, “A Great Injustice to Cheddi Jagan”, 111, 116-117.
} 


\section{The Impact of the Cuban Revolution in British Guiana}

Cheddi Jagan pursued moderate policies and attempted to foster economic progress through interaction with the United States and Great Britain after the election of 1957. However, he also promoted policies aimed at linking the interests of the East Indian community with those of all British Guiana, exacerbating the tensions between the East Indian and Afro-Guianese communities. ${ }^{85}$ Unfortunately for Jagan, the Americans were increasingly preoccupied with the events in Cuba. The United States believed Fidel Castro to be a moderate reformer and supported the Cuban Revolution in its early years. However, after taking over the seat of government in Havana in 1959, the Cubans moved toward alignment with the Soviet Union and the Eastern Bloc. Consequently, the United States' was staunchly opposed to further social movements in the hemisphere and grew even more skeptical of reformist regional leaders. Consecutive American administrations came to understand British Guiana in terms of their experience with Castro in Cuba. The PPP misinterpreted the consequences of Castro’s success and attempted a similar, aggressive foreign policy, increasingly opposing the United States. In April 1960 Cheddi and Janet Jagan visited Cuba and met with Cuban leaders. The Jagans hoped that a show of support for the Cuban Revolution would provide a boon in negotiating for financial aid and economic deals, specifically the sale of rice to Cuba. Meanwhile, the Jagans continued to pursue relations with the Soviet bloc and rhetorically support Marxist ideology. ${ }^{86}$ Cheddi Jagan’s actions solidified the American opposition to his leadership of the colony upon independence.

Great Britain was considerably less skeptical of the threat posed by Castro and Cuba; however, preserving Anglo-American cooperation was a primary concern for the British. Despite

\footnotetext{
${ }^{85}$ Leo Despres offers a comprehensive analysis of the specifics of these policies, specifically educational reforms and rural development projects which disproportionately benefited East Indians and seemed to exclude AfroGuianese. See: Despres, Cultural Pluralism and Nationalist Politics in British Guiana, 240-251.

${ }^{86}$ Kibbe, "Presidents as Kingmakers", 302-304; Rabe, U.S. Intervention in British Guiana, 69-71.
} 
serious disagreements and occasionally contentious exchanges about the situation in British Guiana, the United States and Great Britain formulated a coordinated policy for the colony. After John F. Kennedy assumed the presidency of the United States in January 1961, supporting a staunch policy of anti-communism, both nationalist leaders and colonial governors in British Guiana were forced increasingly to consider the impact of American influence on British plans for decolonization.

\section{Racial Violence, Anglo-American Intervention, and the Progression to Independence}

The stability of British Guiana began to decay as the colony prepared for another round of national elections in August 1961. Stephen Rabe notes that 1961 was a year of hope for the colony. There was relative peace and the promise that the colony would soon be independent. ${ }^{87}$ Jagan and the PPP again were victorious in the elections and the British prepared to grant the colony independence sometime in mid-1962. ${ }^{88}$ However, racial politicking had been a growing factor in Guianese politics, and drastically increased as the elections approached. Ethnic rivalry in the colony would prove to be an ominous sign of events soon to follow. Burnham and the PNC were not content to watch idly as the Jagans and the PPP led the colony to independence. They began organizing a vocal opposition against the Jagans, eventually with financial and strategic support from the United States.

The fate of Cheddi Jagan lay potentially in a visit he made to the United States in October 1961. Jagan was given a spot on the weekly political television news program Meet the Press and slated for an audience with President Kennedy, despite strong resistance from anticommunist hard-liners in the White House. Kennedy had at least verbally agreed to make an

\footnotetext{
${ }^{87}$ Rabe, U.S. Intervention in British Guiana, 76.

${ }^{88}$ Spinner, Political and Social History of Guyana, 89.
} 
effort to work with Jagan after the elections in September. ${ }^{89}$ The October visit provided Jagan with a much needed opportunity to foster beneficial relations with the United States and obtain economic aid crucial for development if the colony was to successfully prepare for independence. Scholars have interpreted Jagan's visit in several ways; however, the most complete explanation is put forth by James McDonald. McDonald explains that in August 1961 several prominent members of the Kennedy Administration, along with the President, decided upon a two-track approach to British Guiana. The first track was used as a manner of placating to British primacy in the colony. It advocated accepting Jagan and minimally cooperating, while "play[ing] political hardball”, in an effort to convince Jagan to pursue alignment with the West. The second track, advanced in conjunction with the first, was to unleash the Central Intelligence Agency (CIA) in the colony and pursue a broad program of subversion, aimed at exploiting Jagan's vulnerabilities and undermining his government by raising questions about his ability to govern in an independent Guyana. Theoretically the second track would be called off if Jagan chose to reconcile with the Anglo-American camp and renounce his communist ideals and support for Cuba. ${ }^{90}$

Jagan's visit conclusively undermined any opportunity he had of averting American intervention, if in fact he had a chance at all. His interaction with broadcaster Lawrence Spivak on Meet the Press was disastrous. Spivak attacked Jagan for his ideological views, drawing the Guianese leader into a philosophical debate which destroyed his credibility to the American public. It is unlikely that the Kennedy Administration would have worked with Jagan unless he agreed to sever ties with Cuba. Jagan's performance on Meet the Press alone nearly sealed his

\footnotetext{
${ }^{89}$ Schlesinger to Kennedy, 12 January 1962, FRUS 1961-1963, 12:261.

${ }^{90}$ McDonald, 384-385.
} 
fate. ${ }^{91}$ Independence for British Guiana during the Cold War would depend in large part on the ability of the colonial leaders to foster cooperative relations with Great Britain and the United States. Jagan’s position as the preeminent politician in British Guiana began to erode quickly after his trip to the United States.

The domestic environment in British Guiana for the next three years was characterized by violence. Endemic racial animosity which had been held at bay for nearly a decade exploded in the capital city of Georgetown after Cheddi Jagan’s budget proposed a restructured tax system which would include several new taxes and a compulsory savings plan. Levies were proposed on capital gains, property, and gifts. A duty proposed on total sales, intended to minimize the ability of firms to avoid income tax by claiming losses each year, was especially incendiary to businessman. ${ }^{92}$ The business community interpreted the scheme to be a redistribution of wealth that was anti-capitalist and argued forcefully against the plan. ${ }^{93}$ Opposition to the budget was not limited to upper class businessmen. The Trades Union Council (TUC), a collective comprised of most of the Guianese labor organizations, also opposed portions of the budget. Specifically, the TUC disproved of the compulsory savings plan in which the government would take a percentage of salaries over \$100 a month and self-employed persons incomes in exchange for government bonds. Additionally, the TUC opposed taxes on luxuries, alcohol and tobacco. ${ }^{94}$ The Jagans’ political foes took advantage of the widespread opposition to his proposals. Realizing that they could not defeat Jagan at the polls, Forbes Burnham, Peter D’Aguiar, the Portuguese head of the United Front (UF), and union leader Richard Ishmael took their political opposition to the streets as Afro-Guianese mobs attacked East Indians, burned their businesses and looted

\footnotetext{
${ }^{91}$ Rabe, U.S. Intervention in British Guiana, 87-89; Spinner, Political and Social History of Guyana, 82-85.

${ }^{92}$ Alexander, A History of Organized Labor in the English -Speaking West Indies, 381.

93 McDonald, “Overriding Interests”, 393-395.

${ }^{94}$ Alexander, A History of Organized Labor in the English -Speaking West Indies, 381.
} 
stores. Seven blocks of the business section of the city burned, and the economy spiraled into a steep decline. ${ }^{95}$

In the United States, most of the high level correspondence on British Guiana remains classified. However, the consensus among respected historians is that the CIA, at the behest of President Kennedy, provided financial assistance for approximately 40,000 striking civil service workers in an effort to undermine Cheddi Jagan. ${ }^{96}$ Stephen Rabe suggests that the CIA used international labor unions as a cover to send financial aid to Burnham. ${ }^{97}$ Ultimately, the domestic crisis compounded the foreign policy issues Jagan's administration was facing and raised further questions about Jagan's ability to head an independent Guyana. The scheme almost worked as Jagan's government only survived the crisis when British troops arrived to re-establish order in the colony two days after the violence had begun. ${ }^{98}$

The Kennedy Administration responded to the unrest in British Guiana by stepping up its pressure on British policymakers for eliminating Jagan as head of the Guianese government. In February 1962 United States Secretary of State Dean Rusk told British Foreign Secretary Lord Alexander Home that the United States would not accept an independent Guyana led by Jagan. He insisted that action had to be taken to avert granting independence until a new government could be placed in office. Rusk’s statement elicited a strong response from British officials who were surprised, angered, and offended by the suggestion that they should subvert a

\footnotetext{
${ }^{95}$ Rabe, U.S. Intervention in British Guiana, 89-94.

${ }^{96}$ McDonald, “Overriding Interests”, 397-398.

${ }^{97}$ There is a strong argument suggesting United States involvement in the domestic violence in British Guiana from 1962-64. See: Gordon Oliver Daniels, “A Great Injustice to Cheddi Jagan: The Kennedy Administration and British Guiana, 1961-63” (Ph.D. Diss., University of Mississippi, 2000) and Stephen Rabe, U.S. Intervention in British Guiana. Also: Stephen Rabe, The Most Dangerous Area in the World: John F. Kennedy Confronts Communist Revolution in Latin America (Chapel Hill: University of North Carolina Press, 1999); Spinner, Political and Social History of Guyana.

${ }_{98}$ McDonald, “Overriding Interests”, 398; Spinner, Political and Social History of Guyana, 96-98.
} 
democratically elected government in their colony. ${ }^{99}$ A series of forceful correspondences were fired back and forth across the Atlantic asserting the inability of the United States to "put up with an independent British Guiana under Jagan” and the astonishment of the British at the Americans' "Machiavellianism”. ${ }^{100}$ Despite considerable animosity toward the hubris of United States officials, Prime Minister Macmillan and the British Government slowly consented to American demands. The independence conference scheduled for May was postponed until October and when it finally took place, there was no discussion of independence. ${ }^{101}$

Tensions remained high into the early months of 1963 and Georgetown was riddled with violence once again, after Jagan passed a labor relations bill intended to ensure workers’ ability to endorse unions of their choice. In mid-April, MPCA and TUC leader Richard Ishmael called for a general strike in the colony. The TUC feared that the bill was a cloak for the PPP to neutralize the influence of the MPCA, which had long represented the colony' sugar workers, and was opposed to Jagan. The TUC suggested that if the bill passed, the PPP would make the Guiana Agricultural Workers Union (GAWU), which was loyal to Jagan, the official union of Guianese sugar workers. ${ }^{102}$ British Guiana was still suffering the damage incurred from the violence of the previous year and the strike further ravaged the economy. Even more devastating to Jagan's position was the inclusion in the strike of a substantial portion of the Civil Service Association. Most of the civil services were manned by Afro-Guianese who had become politically polarized by the racial nature of politics in the colony. The degradation of essential services in British Guiana led to food and oil shortages and by May 9 a state of emergency was

\footnotetext{
${ }^{99}$ Rabe, U.S. Intervention in British Guiana, 93-94.

${ }^{100}$ Memorandum from Rusk to Home FRUS, 1961-1963, 12:544-545.

${ }^{101}$ Rabe, U.S. Intervention in British Guiana, 98; Spinner, 99-100.

102 TNA, CO 1031/4493, Records of the West Indian Department, Note by Colonial Office Information Department: British Guiana Conference Failure of 1962 Deliberations: The Interest Taken by the United Nations, 22 October 1963.
} 
declared by the colonial governor, Sir Ralph Grey. ${ }^{103}$ The strike ended on July 8; however, over the subsequent eighteen months, hundreds of Guianese became victims of the racial violence which continued unabated as a consequence of the decimated economy. ${ }^{104}$ Burnham continued to strengthen his ties to the United States in early May by visiting the United States and meeting with several prominent leaders within the Kennedy Administration, including Arthur Schlesinger, Special Advisor to the President. Burnham argued his case to government officials as well as the general public and garnered considerable support before returning to British Guiana. ${ }^{105}$

Stephen Rabe effectively describes the critical role of American covert assistance in financing Jagan's opposition. However, it is pertinent to note that Burnham and D'Aguiar were opportunistic politicians who would likely have exploited the conditions of racial animosity which existed since the mid-nineteenth century regardless of United States intervention, though it is likely that American assistance significantly increased their effectiveness. Additionally, the United States was not responsible for the disproportionately large percentage of Afro-Guianese who made up the armed civil services. It is important to acknowledge that the United States contributed greatly to Jagan's opposition and unquestionably hastened the elimination of the PPP; however, it is overly simplistic to attribute the racial violence of the independence period to the actions of the United States. Thus, American assistance provided the heat that intensified the fires of tension caused by cultural and social conditions, and ultimately ignited racial warfare as a consequence of the politics of opportunistic Guianese politicians.

\footnotetext{
${ }^{103}$ Spinner, Political and Social History of Guyana, 100-102.

${ }^{104}$ Rabe, U.S. Intervention in British Guiana, 110- 112.

105 McDonald, “Overriding Interests”, 411-413.
} 
The British Guiana Constitutional Conference, held in October 1963, proved to be the coup de grace for Cheddi Jagan. It was clear that discussions between Jagan, Burnham, and D’Aguiar were pointless. The cooperation between the AFL-CIO and Guianese labor unions led Burnham and D’Aguiar to accurately conclude that the United States would support their efforts against Jagan and eliminated the necessity of compromise between the PPP and the emerging PNC/UF coalition. Jagan responded to the stalled negotiations surrounding the proposed new electoral scheme of proportional representation by appealing to the virtue of the British, asking Colonial Secretary Duncan Sandys to arbitrate and resolve the deadlock. ${ }^{106}$ Burnham and D’Aguiar adamantly supported a new system of proportional representation, which increased the possibility of success for a coalition between the two, over the traditional "first past the post" system which favored the population advantage of the East Indians and the PPP. They also vehemently opposed Jagan's proposal to lower the voting age to eighteen which would have proven a boon to the PPP because of the large population of East Indians between eighteen and twenty-one. Sandys decided in favor of Burnham and D’Aguiar on both issues and called for new elections in November 1964, essentially assuring that a PNC/UF coalition would lead the colony to independence if they could cooperate during the upcoming year. ${ }^{107}$

\footnotetext{
${ }^{106}$ Under a system of proportional representation the electorate would vote for a political party, as opposed to a traditional first past the post system in which votes are cast for an individual. Thus, Parliamentary seats would be distributed to each party based on the percentage of the popular vote they received in a system of proportional representation. The United States and Great Britain hoped that alternative East Indian parties would emerge to draw support from Jagan and thus erode the PPP presence in the Guianese government. However, it is important to note that Sandys defended his decision as a radical solution necessary to end racial politics in British Guiana. Sandys argued that under the first past the post system, Guianese citizens voted in racial blocs, regardless of political ideology. He suggested that the emergence of new political parties under proportional representation would increase the potential for the development of ideological political parties and the Guianese would become less constricted by ethnic politics. Sandys suggested that the development of ideologically-based political parties would eventually improve the likelihood that Guianese would vote based on political ideology, not simply ethnicity and improve minority representation in the Guianese government. See: TNA, CO 1031/4405, Records of the West Indian Department, House of Commons Extract From Official Report of Queens Speech Debate-Constitution, 15 November 1963.

${ }^{107}$ Rabe, U.S. Intervention in British Guiana, 118-120; Spinner, Political and Social History of Guyana, 103-104.
} 
Domestic unrest in British Guiana worsened in the early months of 1964 as East Indian sugar workers and staunch PPP supporters took to the streets in response to Sandys' decision. On May 25 Afro-Guianese mobs, retaliating for the mutilation of a black couple, descended on the East Indian village of Wismar raping and pillaging the local population. Over 1,800 people were left homeless as a result of the violence. Despite pleas for assistance, the Afro-Guianese police force failed to control the situation. Janet Jagan resigned her position as Minister of Home Affairs on May 22 in response. She alleged that the police force was no longer operating under the authority of the government and was in fact a tool of the PNC. Cheddi Jagan refused to name a successor to the position as a way of supporting his wife and making a political statement. ${ }^{108}$ On May 27 the new colonial governor, Richard Luyt, declared a state of emergency in the colony. The violence was far from over and political warfare continued at a heightened intensity. Statistics of the year's political violence are telling. Over 200 Guianese died and more than 800 were wounded in 368 racially motivated conflicts during 1964. Some 13,000 Guianese found themselves refugees, most victims of one of the 1,600 cases of arson. ${ }^{109}$ Neither side seemed likely to concede in the midst of the destruction. In fact, the brutality begat only more hostility. Forbes Burnham's response was a reminder that he controlled the Afro-Guianese population and consequently the majority of the armed police force, concluding that his supporters could: "do more killing than [East Indians] could." ${ }^{\prime 10}$ Once again the violence was only halted by the deployment of British troops to the colony. ${ }^{111}$

The Colonial Office scheduled elections for December 7 and the United States government worked diligently to ensure that Cheddi Jagan would not be victorious at the polls.

\footnotetext{
108 Palmer, Eric Williams and the Making of the Modern Caribbean, 225.

${ }^{109}$ Rabe, U.S. Intervention in British Guiana, 125-126; Spinner, Political and Social History of Guyana, 105-106.

${ }^{110}$ Hugh Tinker, The Banyan Tree: Overseas Emigrants from India, Pakistan, and Bangladesh (Oxford: Oxford University Press, 1977), Cited in Rabe, U.S. Intervention in British Guiana, 126.

${ }^{111}$ McDonald, "Overriding Interests", 446.
} 
The AFL-CIO financed anti-Jagan organized labor, primarily in the MPCA, and ran a disinformation campaign aimed at discrediting Jagan. The CIA added to the propaganda operation and organized opposition parties in an attempt to fragment East Indian loyalties, simultaneously advising the PNC and UF and helping them to organize more efficiently. ${ }^{112}$ The British acquiesced to the American tactics, despite strong assertions of opposition to American influence and to proportional representation voiced by the Labour Party in Great Britain. ${ }^{113}$

The election unfolded as the United States and Great Britain had planned. The PPP won more seats than the PNC or UF, but did not obtain the majority which would have given them charge of the government. Governor Luyt requested Burnham and D’Aguiar form a coalition government after an Order in Counsel from London removed Jagan from office. ${ }^{114}$ The United States approved grants to support the coalition within two weeks of its electoral victory, while making it clear to Great Britain that assistance was conditional on Jagan being kept out of any coalition. United States Consul, Delmar Carlson, began advising Burnham and D’Aguiar during 1965 and the Americans pressured Great Britain to grant independence now that Jagan was out of power. ${ }^{115}$

In Great Britain, the Colonial Office and Foreign Office debated throughout the first half of 1965 about the future of British Guiana. The Colonial Office was determined to see progression toward racial cooperation in the colony before granting independence, while the Foreign Office was focused on nurturing the Anglo-American alliance. These competing objectives were complicated by the political rivalry between Burnham and Jagan. Both Guianese leaders made it clear that they were unwilling to work toward any alliance or unification so long

\footnotetext{
112 Rabe, U.S. Intervention in British Guiana, 128-132.

113 Ibid, 133-135.

${ }^{114}$ Ibid, 137; Spinner, Political and Social History of Guyana, 116.

${ }^{115}$ Rabe, U.S. Intervention in British Guiana, 140-141.
} 
as their opponent was included in the government. The Colonial Office conceded that realistic racial reconciliation was unattainable in the near future and international pressure for the British to leave the colony was increasing. Labour Party Prime Minister, Harold Wilson, agreed and determined to convene an independence conference on November 2. The British and Americans either took Burnham at his word that he would work to create a racially integrated society in independent Guyana or they turned a blind eye. Burnham refused to set quotas for civil service employees and made no tangible effort to improve the inequalities in the colony, offering only vague rhetoric suggesting that he would attempt to improve the situation. ${ }^{116}$ The AngloAmerican alliance sacrificed racial collaboration for Cold War imperatives by setting a date for independence without confronting structural issues certain to result in repression of the East Indian population.

The independence period in British Guiana was defined by racial violence and foreign intervention. Domestically, the impact of colonization, both its influence on immigration and social structures, provided the kindling which fueled racial conflict amongst the populace. The geo-strategic importance of the region during the Cold War, examined in detail in the following chapter, led to increasing intervention from the United States and limited the ability of the Guianese to pursue a truly autonomous form of self-government, intensifying the burning discontent of the Guianese people. The fires of racial warfare were ignited when those combustible factors combined with the political opportunism and egoism of Cheddi Jagan and Forbes Burnham, damning British Guiana to a period of intense racial violence and poisoning the independence process in the colony. The following chapter will explore the strategic imperatives of the United States and Great Britain in the Caribbean which framed Anglo-American policy in

\footnotetext{
${ }^{116}$ Ibid, 145-148; Spinner, Political and Social History of Guyana, 119-120.
} 
British Guiana. The subsequent chapter after that will examine the role of Guianese politicians in influencing the turn of events which led to the subversion of the PPP government prior to independence. 


\section{Chapter 3: Anglo-American Cooperation and Strategic Objectives During Decolonization in British Guiana}

The dismantling of the British Empire after 1945 was heavily influenced by the close Anglo-American relationship which grew out of the Second World War. The United States began pressing Great Britain to grant independence to its colonial possessions during the war and by the late 1950s, Great Britain was liquidating its empire. ${ }^{1}$ However, in the early 1960s, United States policymakers adjusted their anti-colonial policy as a response to Cold War developments in the Caribbean, specifically, the Cuban Revolution. American rhetorical support of the right of self-government in colonial areas was subordinated to its Cold War imperatives and American policymakers encouraged British intervention in British Guiana's domestic politics. The American position shifted toward support for a British policy of slow, closely guided, decolonization. However, by 1961, economic constraints and strong international opposition to European colonization led the British to seek a quick withdrawal from British Guiana. ${ }^{2}$ Thus, in British Guiana, traditional roles were reversed as Great Britain sought a quick road to Guianese independence and the United States encouraged a slower approach to decolonization. Both the United States and Great Britain placed the utmost importance on maintaining their special relationship during the Cold War, and negotiating a compromise in order to develop a coordinated policy toward British Guiana was a critical goal of both British and American officials. Ultimately, racial violence, domestic instability, and ineffective Guianese leadership

\footnotetext{
${ }^{1}$ Christophe Thorne, Allies of a Kind: The United States, Great Britain, and the War Against Japan, $1941-1945$ (Oxford: Oxford University Press, 1978); William Roger Louis, Imperialism at Bay: The United States and the Decolonization of the British Empire 1941-45 (New York: Oxford University Press, 1978).

${ }^{2}$ Ronald Hyam, Britain's Declining Empire: The Road to Decolonization, 1918-1968 (Cambridge: Cambridge University Press, 2006).
} 
resulted in converging Anglo-American imperatives and the decision by American and key British officials to intervene in the colony's domestic politics.

As seen in the previous chapter, British Guiana's political and socio-cultural development led to domestic racial conflict, and left-leaning, anti-colonial politics, as the colony progressed toward independence. Domestic violence in British Guiana and heightened Cold War tensions in the post-Cuban Revolution Caribbean led to increasing Anglo-American intervention into Guianese politics. The impact of the Cold War on strategic policymaking in the United States and Great Britain was one of the key factors impacting the trajectory of Britain's decolonization, especially in British Guiana. Anglo-American actions in British Guiana would appear to contradict rhetorical objectives of those nations in regard to ending colonial rule; however, British and American decisions in the colony are best understood by examining the interconnected relationship of the Cold War and decolonization.

This chapter will explore the strategic objectives of the United States and Great Britain in British Guiana within the context of the Cold War and global decolonization. It will discuss how Cold War imperatives influenced the relationship between the United States and Great Britain and how they coordinated a collective strategy in British Guiana. The United States sought to assure that British Guiana established a stable, anti-communist government, aligned with the United States, before it was granted independence. Great Britain’s primary goals in British Guiana were to establish a stable government, capable of quelling racial violence after the withdrawal of British soldiers from the colony, and maintaining the special relationship with the United States. Ultimately, the United States determined that its Cold War objectives in the Caribbean could be met only if Cheddi Jagan and the People's Progressive Party (PPP) were removed from power in British Guiana. Key British policymakers, specifically Commonwealth 
Secretary Duncan Sandys, also concluded that Jagan and the PPP were incapable of effectively leading the government. His decision was based on a combination of American pressure and Jagan's inability to control domestic violence. ${ }^{3}$ Thus, the United States and Great Britain came to a mutual decision to pursue a course to eliminate the PPP government and replace it with a coalition government between Forbes Burnham’s People’s National Congress (PNC) and Peter D’Aguiar's United Front (UF).

Despite scholarly criticism of United States fears in Latin America as overblown, there existed a legitimate threat of communist infiltration in British Guiana, and a real concern for instability spreading throughout the region. Scholars such as Richard Barnet and Stephen Rabe suggest that American policymakers were blinded by a Cold War lens, which doomed them to misinterpret the intricacies of politics in developing areas. ${ }^{4}$ Rabe's U.S. Intervention in British Guiana suggests that American policymakers convinced themselves that Cheddi Jagan would attempt to turn British Guiana into a replica of Fidel Castro’s Cuba if he were allowed to be the head of an independent government in British Guiana. ${ }^{5}$ Rabe notes that high level American officials based their opposition on circumstantial evidence which led them to draw conclusions about Jagan that were not corroborated by their British counterparts or even some lower-level American officials in British Guiana. ${ }^{6}$ This chapter will expand on the American contextualization of British Guiana as a key component of Cold War geo-political strategy. It suggests that American concerns about instability in British Guiana were based on a logical

\footnotetext{
${ }^{3}$ The National Archives, Kew, Richmond, Surrey (hereafter TNA), Colonial Office (hereafter CO) 1031/4405, Records of the West Indian Department, Duncan Sandys, House of Commons Extract from Official Report of Queens Speech Debate-Constitution, 15 November 1963.

${ }^{4}$ Richard Barnet, Intervention and Revolution: The United States in the Third World (New York: The World Publishing Company, 1968); Stephen G. Rabe, U.S. Intervention in British Guiana: A Cold War Story (Chapel Hill: The University of North Carolina Press, 2005).

${ }^{5}$ Rabe, U.S. Intervention in British Guiana, 47-48.

${ }^{6}$ Ibid, 177, 179.
} 
assessment of regional Cold War imperatives and domestic unrest in British Guiana itself.

This chapter suggests that the British decision to subvert the PPP cannot simply be attributed to their acquiescence to American demands. It is not a justification of Anglo-American intervention; rather, it is a more nuanced explanation for the reasons behind the opposition to Jagan which led to such a policy. British Guiana is a useful microcosm with which to understand the complex dynamics involved in developing and instituting a coordinated Anglo-American foreign policy in the Caribbean. Great Britain toiled diligently in an effort to prepare British Guiana for independence in a manner that facilitated stability in the colony and enhanced British standing in the international community. International pressures and fiscal realities demanded the utmost efficiency and speed from British administrators in granting independence to British Guiana. This chapter will focus on the broad geo-strategic reasons for the Anglo-American decision to support Forbes Burnham, rather than Cheddi Jagan, as the individual best suited to lead the Guianese government during the transition to independence.

Anglo-American strategic imperatives after World War II were framed by the dual dynamics of the Cold War and global decolonization. In the wake of the Second World War, many former colonies of European powers rapidly attained sovereignty. The aftermath of the war also led to the global power struggle between the United States and the Soviet Union. However, the Cold War and decolonization cannot be understood without considering how each phenomenon influenced the other. Each newly independent government represented an ideological and strategic battleground in the struggle for dominance between the Soviet Union and the Western bloc nations, primarily the Anglo-American alliance of the United States and Great Britain. Economic alliances, ports, military bases, and raw materials were at stake in each former colonial area when it gained independence. The Anglo-American alliance and the Soviet 
Union were competing for global influence during a period which saw the world's political structures reordered with a totality and speed unparalleled in history. The uncertainty, internal power struggles and instability inherent in the process of decolonization provided the fertile ground on which the Cold War was fought, and the Cold War framed the nationalist struggles which emerged during global decolonization. Thus, the dual dynamics of the Cold War and decolonization created a global power struggle between the United States and the Soviet Union, former colonial powers, and nationalists in the developing world.

It is relevant to consider briefly the global climate during the decolonization period in British Guiana, defined in this paper as 1953 to 1966, when evaluating British and American involvement in the colony. Beginning in 1952 and surging forward in early 1953, the Mau Mau uprising in Kenya stressed to British officials the potential for instability in colonies as they prepared for independence. ${ }^{7}$ In July 1953 the Korean War was suspended with the signing of an armistice between communist North Korea and the Western supported South Korea. There was no peace treaty signed, however, and the region was still quite volatile. The Korean War dramatically increased Western fears of communist expansion. Simultaneously, fears of a communist infiltration in Guatemala resulted in a United States intervention in 1953-54, for some of the same reasons which caused the British to intervene in British Guiana in 1953; namely, left-leaning social reforms. ${ }^{8}$ The Cold War and the decolonization process increased in intensity throughout the 1950s and 1960s. The interrelation of the two global trends, as this chapter shows, led to a concurrent increase in British and American concern with the political

\footnotetext{
${ }^{7}$ David Anderson, Histories of the Hanged: Britain's Dirty War and the End of Empire (New York: W.W. Norton and Company, 2005).

${ }^{8}$ Nick Cullather, Secret History: The CIA's Classified Account of its Operations in Guatemala, 1952-54 (Stanford, California: Stanford University Press, 1999).
} 
development of British Guiana, reaching a fever pitch during the final stages of decolonization in the colony.

\section{The Anglo-American Special Relationship}

The collaboration between the United States and Great Britain which came to be known as the special relationship began during World War II. The Allied Nations, specifically the United States and Great Britain, coordinated policy and military efforts out of necessity to defeat Nazi Germany, Italy, and imperial Japan during the war. Throughout the war, the AngloAmerican alliance overcame several contentious issues, none more intense than the debate over the post-war fate of European colonies. ${ }^{9}$ The United States and Great Britain maintained their wartime alliance as a deterrent to post-war Soviet expansion. The issue of colonialism, contentious during the war, resurfaced in its aftermath as the issues which were suspended to combat the threat at hand emerged with even more force during the early Cold War.

The union forged between Great Britain and the United States emerged from the ashes of the Second World War altered, but intact, despite severe disagreement on the future of the British Empire. As the inevitability of decolonization became increasingly apparent, the United States and Great Britain faced the dual challenge of simultaneously dismantling the British Empire and waging the Cold War. The role of being the leading global power was no longer the preserve of Great Britain as it had been prior to World War II. However, the British maintained considerable input into the global strategy of the Anglo-American alliance during the Cold War, despite ceding the leadership role to the United States by mid-1943. It is crucial to understand that neither the United States, nor Great Britain, developed a foreign policy independent of the

\footnotetext{
${ }^{9}$ Christophe Thorne, Allies of a Kind: The United States, Great Britain, and the War Against Japan, 1941-1945 (Oxford: Oxford University Press, 1978); William Roger Louis, Imperialism at Bay: The United States and the Decolonization of the British Empire 1941-45 (New York: Oxford University Press, 1978).
} 
other. They maintained a close, though at times contentious alliance, cooperating on most major issues relating to decolonization and Cold War strategy. The Anglo-American relationship in British Guiana took a form similar to competing departments within a government. Each advanced its own interests, within an established framework, and ultimately they formulated a collective policy. The United States and Great Britain were cognizant of the broad, strategic imperatives of their trans-Atlantic partnership.

In British Guiana, Cheddi and Janet Jagan posed a serious challenge to British and American strategic interests during the Cold War and the decolonization of the British West Indies. Cheddi Jagan was outspoken in his belief in Marxist ideology, and Janet had been an active communist party member in Chicago before marrying Jagan and moving to British Guiana. The United States strongly opposed the implications of the Jagans leading a postcolonial Guianese government, especially after the Cuban Revolution in 1959. The British considered the Cold War implications of post-Castro Caribbean, but were primarily influenced in their actions by the effect the government would have on preparing the colony for independence. Great Britain’s concern with Cold War strategy was tempered by the need to establish a popular, stable government in Guiana. Great Britain, more so than the United States, needed to strike a balance between Cold War strategy and the realities of decolonization.

The United States was more singularly focused on Cold War imperatives; however, they took into account British interests, as well as the international consequences for their ally, should the British acquiesce to American imperatives in the region. United States officials understood that Great Britain’s primary objective was to leave British Guiana in a quick and dignified 
manner, and they at least considered British aims during the policymaking process. ${ }^{10}$ British officials were equally conscious of the American imperatives in the region, such as the significance of the American relationship with Venezuela. ${ }^{11}$ Thus, Great Britain and the United States sought to understand each other's interests and accommodate them in order to create a more stable Anglo-American cooperation during the Cold War.

\section{Anglo-American Perspectives in British Guiana}

The prism through which the United States and Great Britain interpreted regional events framed Anglo-American imperatives in the Caribbean. Instability and subsequent violence in the Congo during its transition to independence, and memories of the partition of India weighed heavily on British administrators. Cold War perspectives in the United States were greatly skewed by contemporary experiences with the revolutionary government in Cuba, the geostrategic significance of British Guiana, the economic importance of Venezuela, and were compounded by the increasing activity of communist parties in the region. Cold War ideology provided the overarching perspective with which the United States formulated its policy toward British Guiana. Consequently, Great Britain had to consider the Cold War implications of an independent Guyana to a much greater degree than other regions of its empire undergoing decolonization during the decade. The British held a more nuanced understanding of the subtleties of domestic politics in their colony, as well as of Burnham and Jagan as individuals. Ultimately, despite harboring deep reservations, they actively supported Burnham, acquiescing to pressure from the United States.

\footnotetext{
${ }^{10}$ Gordon Knox to William. Burdett, Contingency Planning for British Guiana, 2 October, 1962, Br. Guiana Briefing Papers 1.8, RG 59, Records of the Department of State, National Archives II, College Park, MD.

${ }^{11}$ The National Archives, Kew, Richmond, Surrey (hereafter TNA), Foreign Office (hereafter FO) 371-179146, General Records of the American Department, Note from John Killick of the British Embassy, Washington to Jack Rennie of the Foreign Office, 3 November1965.
} 
Vice-President Richard Nixon's South American tour in 1958 contributed considerably to how the United States viewed Latin America. Regional opposition to United States policies was strong, specifically in British Guiana’s western neighbor, Venezuela, where Nixon was attacked by a mob. American policymakers interpreted the negative response to the Vice President's trip within the context of the Cold War. The United States Information Agency concluded that Nixon's poor reception was due to the increased influence of the Soviet Union and China, who the Americans suspected of providing significant material and moral support for regional communist parties. ${ }^{12}$ That the most intense opposition to Nixon's visit occurred in British Guiana's western neighbor, Venezuela, was not lost on policymakers in Washington. The United States State Department noted that legalization of communist parties in Colombia, Venezuela, and Chile, stimulated similar movements in neighboring countries and that the Communist Party of Venezuela was: "the most vociferous and fastest-growing legal communist party in the Western Hemisphere." ${ }^{13}$ In the minds of United States policymakers, the presence of active communist threats in Venezuela and British Guiana reinforced the importance of both areas to the overarching Cold War strategy.

The Cuban Revolution and the Twenty-first Communist Party Congress in Havana in 1959 persuaded the United States to take a more proactive position to assert its aims in the region. In January 1959 the State Department concluded that the Soviet Union would attempt to use Fidel Castro’s Cuban Revolution as a means of undermining the United States position in Latin America and that the logical response was a more stringent opposition to regional anti-

\footnotetext{
${ }^{12}$ U.S. Information Agency Library, Central Research Unit. Soviet Hopes for Latin American Communism, 21 November 1958, Communism-Anti-Communism Campaign Task Force 1958, RG 59, Records of the Department of State, National Archives II, College Park, MD.

${ }^{13}$ Memorandum from U.S. Information Agency to Department of State, 31 December 1958, Communism in Latin America, 1958, Communism General 1959, RG 59, Records of the Department of State, National Archives II, College Park, MD.
} 
American movements. ${ }^{14}$ The harder line the United States took after 1960 is increasingly evident in British Guiana. Simultaneously, the success of the Cuban Revolution implanted within United States policy an ever-present trepidation that further revolutions in the hemisphere could occur. Cuba's active role in the exportation of revolution in the early 1960s resulted in an increasingly strict anti-communist mentality in United States politics. ${ }^{15}$ The fear that Cheddi Jagan was another Castro; “a wolf in sheep’s clothing,” dominated the decision making process of American policy makers as British Guiana marched toward independence in the early 1960's. ${ }^{16}$ Ultimately, the Cuban Revolution narrowed the American perception of what constituted legitimate nationalist movements, specifically in the Western Hemisphere.

United States policymakers interpreted the PPP’s foreign policy, specifically its communist associations and rhetorical support for the Cuban Revolution, as a clear indication that American inaction would lead to a second communist government takeover in the hemisphere, this time on mainland South America. ${ }^{17}$ While British policymakers were less confined by Cold War perceptions than their American counterparts, they too acknowledged the Jagans accumulating ties to international communism. British colonial officials noted, with concern, the establishment of closed mail bag service with Communist China, the presence of Venezuelan and Cuban Communists advisors to the PPP, the British Guiana Electricity Corporation's decision to purchase fuel exclusively from Cuba, the presence of Cuban rice

\footnotetext{
${ }^{14}$ Note from S/P- Mr. Smith to ARA-Mr. Rubbotom. Post Summit Policies, 30 June 1960, Policy (ARA Files) 1960, RG 59, Records of the Department of State, National Archives II, College Park, MD.

${ }^{15}$ Note From S/P- Mr. Smith. ARA-Mr. Rubbotom. Post Summit Policies,30 June 1960. Policy (ARA Files) 1960, RG 59, Records of the Department of State, National Archives II, College Park, MD.

${ }^{16}$ Memorandum from Mr. Rubottom to the Secretary, 9 June 1960, RG 59, Records of the Department of State, National Archives II, College Park, MD.

${ }^{17}$ Memorandum from Mr. Rubottom to The Secretary, 9 June 1960. RG 59, Records of the Department of State, National Archives II, College Park, MD; Deputy Director Office of British Commonwealth and Northern European Affairs M. Gordon Knox to P-Mr. Manning, 11 March 1963, General Records of the Department of State: Bureau of Inter-American Affairs, Office of Director of Caribbean Countries Records Relating to British Guiana 1957-74.BG2-POL, RG 59, Records of the Department of State, National Archives II, College Park, MD.
} 
vessels in Georgetown, and the flow of Cuban political and technical advisors in and out of the colony. ${ }^{18}$ The communist leanings of Cheddi and Janet Jagan and mounting domestic instability in British Guiana altered the British perspective on how to best withdraw from the colony by 1963, shifting their views closer to those of the United States, who sought to establish a working relationship with Forbes Burnham.

The most important aspect of American preoccupation with British Guiana was the colony's ideological significance. Policymakers in the United States feared that the perception of having lost a second Western Hemispheric nation to communism would severely damage the standing of the United States among other Latin America and Caribbean nations. The British, also concerned with the ideological significance of British Guiana, feared that permitting a communist government takeover in the colony could set a precedent for other decolonizing areas where economic ties were considerably more important, such as Singapore. Thus, British Guiana represented a threat to British control of the decolonization process in their colonies and the ability to define post-colonial relationships. ${ }^{19}$ Additionally, British officials feared that if a communist government in British Guiana nationalized private companies it would lead to further nationalization within the region, specifically in Britain's other West Indian colonies. In fact, this fear was substantiated in 1974 when the former West Indian colonies, led by British Guiana, nationalized the Caribbean bauxite industry. ${ }^{20}$

British Guiana held other significance for Great Britain. The British were knee deep in the dismantling of their empire, and wanted nothing more than to rid themselves of the burden of

\footnotetext{
${ }^{18}$ TNA, CO 1031/4866, Records of the West Indian Department, British Guiana: Anglo/US Exchange on Status and Prospects of Political Developments, 13-14 December 1963.

${ }^{19}$ Hugh Cumming, Director of Intelligence and Research to EUR. Intelligence, Note: Cuban Loan to British Guiana, B.G.-Cuba 10.3 RG 59, Records of the Department of State, National Archives II, College Park, MD.

${ }^{20}$ Rabe, U.S. Intervention in British Guiana, 164-165.
} 
what had become an economically draining, politically obstinate West Indian colony. The British struggled to determine how best to prepare the colony for independence, at the earliest possible date. Great Britain took pains to preserve a sense of national pride while their empire was being deconstructed and the British were anxious to achieve a stable and democratic conclusion to their colonial legacy, specifically in a relatively insignificant territory like British Guiana. ${ }^{21}$ British officials were conscious of the potential for violent consequences resulting from prematurely granting independence, as they had in India, which resulted in ethnic warfare which left millions dead. ${ }^{22}$ Thus, British administrators sought to grant independence only when the Guianese were prepared to maintain a stable self government.

Internal politics within Great Britain and the United States contributed to the development of the foreign policy objectives of each nation. If British Guiana established a communist government, the American public likely would perceive the incumbent government as having lost the country to communism. The domestic political ramifications to the administrations of Presidents John F. Kennedy and Lyndon Johnson would have been even more disastrous than the perceived loss of stature in the international community. British officials were aware that neither Kennedy nor Johnson could hope to be re-elected if a communist government was established in British Guiana. ${ }^{23}$ Deputy Director for the CIA, Richard Helms, wrote to National Security Advisor, McGeorge Bundy, in July 1964: "when the British inquired what policy might be should Jagan win, we reiterated that such a situation would be politically

\footnotetext{
${ }^{21}$ TNA, CO 1031/4866, Records of the West Indian Department, Note from John Hennings of British Embassy, Washington D.C. to Ambler Thomas of Colonial Office, 15 February 1963.

${ }^{22}$ Yasim Kahn, The Great Partition: The Making of India and Pakistan (New Haven: Yale University Press, 2007).

${ }^{23}$ Note From Gordon Knox to William Burdett. Contingency Planning for British Guiana, 2 October, 1962, Br. Guiana Briefing Papers 1.8, RG 59, Records of the Department of State, National Archives II, College Park, MD; TNA, CO 1031/4865, Records of the West Indian Department, Telegram no. 174 from Sir Patrick. Dean to Foreign Secretaries and Commonwealth Secretaries. 14 October 1965.
} 
intolerable in the United States." ${ }^{24}$ Thus, the strength of American opposition to Jagan made cooperation between the United States and Great Britain difficult. British leaders were forced to make concessions to American leadership to maintain the special relationship with the United States without appearing to kowtow to American interests.

Finally, British imperatives in their colony were framed by fiscal realities. Great Britain was financially incapable of supporting Guyana's development alone. Efforts were made to incorporate the former British Dominion of Canada into British Guiana's future development plans on the premise that the Canadians had substantial investments in Guianese bauxite and the Canadians appear to have shown an interest in exerting influence among former British colonies in the hemisphere. ${ }^{25}$ British documents, however, belie a certain realization by the British that Canadian cooperation could never replace the level of assistance that the United States could offer. Thus, it was necessary for British officials to appease American policymakers to obtain financial and material aid from the United States for post-independence development. ${ }^{26}$

Additionally, British policymakers maintained a certain level of anxiety about the United States response if Great Britain failed to account for American objectives in British Guiana. ${ }^{27}$ British officials maintained a persistent fear that if British Guiana became independent with the PPP and

\footnotetext{
${ }^{24}$ Helms to Bundy, 17 July 1964, FRUS 1964-1968, 32:385.

${ }^{25}$ TNA, CO 1031/4866, Records of the West Indian Department, British Guiana: Visit to Ottowa, 9 April 1964; TNA, CO 1031/4866, Records of the West Indian Department, Paper for the Defense of Overseas Policy, 21 June 1964.

${ }^{26}$ TNA, CO 1031/4867, Records of the West Indian Department, Memorandum from Secretary of State to Robin Piper: British Guiana: American Aid, 23 December 1964.

${ }_{27}^{27}$ TNA, CO 1031/4866, Records of the West Indian Department, Paper for Defense/Overseas Official Policy, British Guiana: Political Situation, 21 June 1964.
} 
Cheddi Jagan in power, the colony could follow a pattern similar to Cuba and result in U.S. intervention. $^{28}$

Therefore, despite the pretense on the part of both the British and the United States of the British developing an independent policy in the colony, the reality was quite different. While the British formulated plans which assumed disagreement with their North American partner, they never pursued policies that did not work in conjunction with United States interests in the region. ${ }^{29}$ For their part, United States policymakers understood that despite its geographical proximity to the United States, Guiana was a British colony, and the British would be required to implement any strategy agreed upon. Internationally, the situation was delicate. Neither nation wished for it to appear, in the eyes of the international community, as though the United States was intervening in British-Guianese relations. ${ }^{30}$

Internal policy, international pressure, and the geographical importance of the colony to the United States at the height of the Cold War, as well as British pride, made proper preparations for independence imperative. Neither the United States nor Great Britain would accept that a former British colony was fated to be an unprepared, unstable, developing nation on the Caribbean. Great Britain strived to ease racial violence and stabilize the domestic situation within the colony, and to establish an efficient, functioning government that could avert the instability and violence that plagued many other post-colonial areas. The United States was conscious of its partner's difficult situation. American officials were prepared to consider the British desire for a rapid transition to Guianese self-government while discussing how to avoid

\footnotetext{
${ }^{28}$ TNA, CO 1031/4866, Records of the West Indian Department, Brief For Prime Minister's Talks with President Kennedy, Prepared by the Colonial Office, June 1963.

${ }^{29}$ TNA, CO 1031/4866, Records of the West Indian Department, British Guiana: Anglo-U.S. Consultations on Future Co-operation, 14-16 October 1963.

${ }^{30}$ TNA, CO 1031/4866, Records of the West Indian Department, British Guiana: Anglo-U.S. Consultations on Future Co-operation, 14-16 October 1963.
} 
post-colonial violence, as in the Congo, prior to the United States-United Kingdom talks in March, 1961. ${ }^{31}$

United States policy makers were well aware of the value Great Britain placed on successfully leaving its colonies, and sought to avoid unnecessary conflict with the British. Assistant Secretary of State William Burdett made clear in a position paper for the State Department in 1962 that he understood that the British hoped to leave British Guiana in an honorable fashion. However, he also realized that the British would not strain Anglo-American relations to achieve their aims in the colony. ${ }^{32}$ Similarly, United States officials valued their alliance with Great Britain above achieving the totality of their own strategic imperatives. Initially, this goal seemed an undertaking best achieved by working with Cheddi Jagan and the PPP, as evidenced by the Kennedy Administration policy of working with Jagan put forth in September, 1961. ${ }^{33}$ United States reluctance and eventual outright refusal to accept this policy impacted British planning. From 1953 to 1966 the United States and Great Britain gave increasing consideration to the Cold War implications of decolonizing in the Caribbean. Working within the framework of the Anglo-American relationship of the Cold War, the British began exploring options in the colony which were more palatable to their partner. Jagan’s continual pursuit of communist ties and the increasing instability in the colony which resulted from his domestic policies, pushed the British further into the American camp. Eventually, British concerns over the instability which would surround a Jagan-led government at

\footnotetext{
${ }^{31}$ Secretary's Talks With United Kingdom Ambassador ,14 March 1961, Colonialism and the UN, US-UK TalksFeb-Mar 61, RG 59, Records of the Department of State, National Archives II, College Park, MD.

${ }^{32}$ Position Paper by William Burdett on Prime Minister MacMillan’s Visit to Washington, 20 April 1962, RG 59, Records of the Department of State, National Archives II, College Park, MD.

${ }^{33}$ Schlesinger, A Thousand Days, 778; William Tyler to The Under Secretary, The United States Policy Towards British Guiana. 1 December 1961, Br. Guiana-US Position Papers (AID), RG 59, Records of the Department of State, National Archives II, College Park, MD.
} 
independence coupled with American pressure, led the British to acquiesce and support the Burnham coalition to lead the colony to independence.

\section{Instability}

The United States interpreted racial violence, and perhaps abetted it, within the context of their Cold War strategic concerns, while the British considered how domestic unrest in British Guiana would affect decolonization. The United States saw instability as a potential opening that communist subversives could exploit to gain support, while the British were alarmed at the possibility of post-colonial internal instability, and perhaps even civil war. ${ }^{34}$ The coming of independence in the colony heightened existing racial tensions, and made the resolution of instability crucial to the successful implementation of an autonomous government in the colony. British officials were primarily concerned with the international consequences if violent instability followed independence in the British Guiana. British prominence in the international community hinged on the efficient and peaceful transition of its colonies to independence. The British felt a strong need to maintain strong international support during the period of the Cold War and decolonization..$^{35}$ International support could be seriously compromised if Guianese independence led directly to racial warfare. British Guiana’s instability had different implications for the United States. The American fear that communist subversives would exploit domestic instability in British Guiana was largely a consequence of the geographic importance of British Guiana to the American Cold War strategy. American officials feared the regional repercussions if British Guiana established a communist government after independence, specifically the possibility of Venezuela, Brazil, and the Caribbean, especially Cuba, becoming destabilized.

\footnotetext{
${ }^{34}$ TNA, FO 371-179146, General Records of the American Department, Brief for Prime Minister’s Visit to Washington, 3 December 1965.

${ }^{35}$ Hyam, Britain's Declining Empire.
} 
The consequences of inadequately confronting sectarian tensions in the Indian subcontinent prior to independence contributed significantly to British perspectives on decolonization. Great Britain condemned the region to a period of incredible violence followed by persistent tensions between India and Pakistan by prematurely granting independence to the region. ${ }^{36}$ British fear of instability in British Guiana was heavily influenced by the violent conflicts which erupted in the Congo following its independence from Belgium as well. ${ }^{37}$ The Guianese themselves were fearful of internal instability. Racial tensions had increased over the decade preceding independence and were boiling over by 1962. The primarily urban AfroGuianese community and the rural East Indians who comprised the majority of the population were increasingly in conflict. Guianese leaders, specifically Jagan and Burnham, exploited racial dissension by engaging in race-based politics hoping to gain a political advantage. The Central Intelligence Agency (CIA) contributed to the strife in hopes of undermining the Jagan-led government. Although the precise beginning of American involvement is uncertain, it clear that by February 1962 at least some elements of the American government were actively working to subvert the PPP. ${ }^{38}$ The result was an increasing racial polarization of Guianese society. ${ }^{39}$ Several influential members of the Corentyne East Indian community met with Vice Consul Joseph Johnson in March 1963 and voiced their concerns. The Guianese were hesitant to push for an end to British rule due to conditions of racial animosity in the colony, as well as minimal educational opportunities, and the lack of a diversified economy. ${ }^{40}$ Johnson felt that the only means of

\footnotetext{
${ }^{36}$ Yasim Khan, The Great Partition: The Making of India and Pakistan ( New Haven: Yale University Press, 2007).

${ }^{37}$ William Roger Louis, Ends of British Imperialism: The Scramble for Empire, Suez and Decolonization (London: I.B. Tauris, 2006), 496-499,701-702.

${ }^{38}$ Rabe, U.S. Intervention in British Guiana, 91.

${ }^{39}$ Thomas Spinner, A Political and Social History of Guyana 1945-83 (Boulder: Westview Press, 1984).

${ }^{40}$ Memorandum of Conversation, Corentyne East Indians Comment on BG Politics, 2 March 1963, General Records of the Department of State: Bureau of Inter-American Affairs, Office of Director of Caribbean Countries Records
} 
establishing stability was to implement the controversial system of Proportional Representation prior to independence and eliminate Jagan as the head of the government. He determined that the PNC would attempt to wrest control of the government from the PPP if Burnham lost a traditional election, making proportional representation necessary to avoid civil war. ${ }^{41}$

In addition to strong fears of a communist takeover of the government, the Kennedy Administration was apprehensive about the domestic consequences of instability in British Guiana. There was a legitimate threat of civil war if the Guianese people were granted independence under a PPP government. British Guiana’s segregated population, discussed at length in chapter one, helped create this instability. Forbes Burnham used the Afro-Guianese population which dominant the capital city of Georgetown to maintain control over organized urban labor unions as well as the vast majority of the civil services. British colonial officials and Jagan thought it critical to correct racial imbalances in the police force before independence. ${ }^{42}$ However, Jagan’s efforts to implement a predominantly East Indian security force were met with opposition from the PNC as well as the United States. ${ }^{43}$ Burnham made clear that he was willing to use force to gain power if Jagan attempted to develop an armed East Indian security force after

Relating to British Guiana 1957-74, POL-Political Affairs Memcons (BG), RG 59, Records of the Department of State, National Archives II, College Park, MD.

${ }^{41}$ Memorandum of Conversation between Mr. E.H. Barrow and Joseph R. Johnson, 21 February 1963, General Records of the Department of State: Bureau of Inter-American Affairs, Office of Director of Caribbean Countries Records Relating to British Guiana 1957-74, RG 59, Records of the Department of State, National Archives II, College Park, MD.

42 TNA, CO 1031/4408, Records of the West Indian Department, Memorandum of Conversation between Colonial Governor Richard Luyt and Forbes Burnham, January 1965; TNA, CO 1031/4408, Records of the West Indian Department, Note from Richard Luyt to Colonial Office, 12 March 1965; Memorandum of Conversation between Richard Luyt and Cheddi Jagan, 29 August 1964; TNA, CO 4407, Records of the West Indian Department, Memorandum of Conversation between Richard Luyt and Cheddi Jagan, 22 September 1964

${ }^{43}$ TNA, CO 1031/4408, Records of the West Indian Department, Memorandum of Conversation between Colonial Governor Richard Luyt and Forbes Burnham, January 1965. 
independence. ${ }^{44}$ Additionally, British documents indicate independence under Burnham brought the possibility of a similar conflict. ${ }^{45}$ Cheddi Jagan sought to strengthen the East Indian position in the event of armed struggle by importing automatic weapons, almost certainly from Cuba, and seeking military assistance from Israel. ${ }^{46}$ Thus, the Anglo-American decision to support Burnham was a pragmatic way to avoid violent instability, since Burnham already controlled the armed forces, in what was a geographically strategic region.

The somber consequences which faced the colony if the civil services remained racially segregated became clearer as violence became endemic. By 1962, domestic violence in British Guiana was no longer a threat, it was a reality. Labor unrest had devolved into racial violence, spreading from the capital city of Georgetown to New Amsterdam and throughout the colony. The racially polarized civil services proved inadequate for combating this violence. Frequently, the uneven racial composition of the police force was the cause of much of the conflict. East Indians directed most of their aggressions against the predominantly Afro-Guianese police force and the police force was the source of considerable violence toward the East Indian community. ${ }^{47}$ The PPP perpetuated the cycle of violence in the colony by supplying arms to the East Indian community and organizing strikes.

In 1963 several East Indians were arrested with machine guns, weapons which were not regularly available in British Guiana. British intelligence surmised that Jagan’s government was

\footnotetext{
${ }^{44}$ Memoranda from American Consol General Everett Melby to Secretary of State, 05 September 1962, RG 59, Records of the Department of State, National Archives II, College Park, MD; TNA, CO 1031/4407, Note by West Indian Department B: "British Guiana: After the Elections” 30 November 1964.

${ }^{45}$ TNA, CO 1031/4866, Records of the West Indian Department, Brief for Prime Minister's Talks with President Kennedy: British Guiana, Joint Assessment by U.S. and British Officials, June 1963.

${ }^{46}$ Memorandum from Thomas Hughes to William Burdett, 27 November 1963, RG 59, Records of the Department of State, National Archives II, College Park, MD.

${ }^{47}$ Rabe, U.S. Intervention in British Guiana, 126-27.
} 
smuggling the weapons into the British Guiana from communist nations in the region. ${ }^{48}$ The violence and instability in the colony in 1963 was quelled by the arrival of British troops, as it had been the previous year. The PPP's inability to maintain internal stability eroded British confidence in the Jagan-led government. ${ }^{49}$ By 1964 bureaucratic strain resulted in the splintering of the civil service structure, and racial tensions between the police force and the government resulted in Janet Jagan’s resignation as Minister of Home Affairs. ${ }^{50}$ The instability of governmental institutions was compounded by the fact that Burnham was openly considering the possibility of armed revolt if the PPP remained in power after independence ${ }^{51}$ Correcting the racial imbalance in the Guianese civil services prior to granting the colony independence was of paramount importance to the British and the significance of this issue increased as that time approached and violence increased. Thus, while the Colonial Office hoped to grant independence to British Guiana as quickly as possible, structural issues worked in concert with American pressure to slow down the process of decolonization.

In addition, Great Britain’s fear of communist subversion in the colony was coupled with apprehension at the possibility of the United States intervening to counter that threat. Prime Minister Macmillan’s briefing prior to meeting President Kennedy noted that: “The British Guiana government has been increasingly in contact with Cuba, Russia and other bloc countries and there can now be little hope that on independence it would not follow the pattern of Cuba. This would no doubt evoke a strong reaction in Latin America (as well as in the U.S.) with the

\footnotetext{
${ }^{48}$ TNA, CO 1031/4407, Records of the West Indian Department, Memorandum of Conversation between Colonial Governor Richard Luyt and Cheddi Jagan, 25 June 1964.

${ }^{49}$ TNA, CO 1031/4493, Records of the West Indian Department, Colonial Office Information Department: British Guiana Conference Failure of 1962 Deliberations: The Interest Taken by the United Nations, 22 October 1963.

${ }^{50}$ Spinner, A Political and Social History of Guyana, 106.

${ }^{51}$ Memorandum from Mr. Rubottom to Mr. Smith, 13 July 1960, RG 59, Records of the Department of State, National Archives II, College Park, MD.
} 
possibility of intervention.,52 British suspicions of United States intervention were well founded. Formerly classified United States State Department records indicate that: “...if the PPP makes an effort to take over the country by force, the U.S. government will not stand by and see opposition crushed by terror. ${ }^{, 53}$ Failed attempts at intervening in Cuba and the subsequent international embarrassment tempered calls for intervention in the United States, but it did not eliminate them.

\section{Geo-political Significance of British Guiana}

British Guiana held a geo-strategic importance for the United States beginning with the acquisition of Atkinson Airfield as a result of the Destroyer for Bases Deal with Great Britain in $1940 .{ }^{54}$ Atkinson Airfield was a significant aspect of United States hemispheric military hegemony critical to American Cold War strategy. American officials felt that the United States could not afford to lose the base in the event of a communist government coming to power in British Guiana. In an internal memorandum for the Office of the Assistant Secretary of Defense, William Lang wrote: “...the Air Force is concerned with the need to retain available military 'toe-holds' on the South American continent for possible use in contingency operations in the area,” and he continued: “...while there is no present need for the facilities in B.G....a future requirement for their use may arise either in connection with developments in our missile and

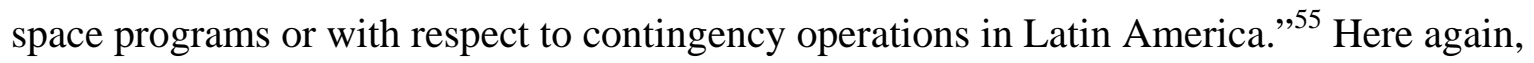
British Guiana is seen as a crucial aspect of the United States Cold War regional strategy.

\footnotetext{
${ }^{52}$ TNA, CO 1031/4866, Records of the West Indian Department, Brief For Prime Minister's Talks with President Kennedy, Prepared by the Colonial Office, June 1963.

${ }^{53}$ Telegram from the Department of State [text not declassified] to the Consulate General in British Guiana, 13 May 1964. FRUS: 1964-68, 32:377.

${ }^{54}$ Rabe, U.S. Intervention in British Guiana, 22.

${ }^{55}$ Office of the Assistant Secretary of Defense William Lang to Gerald Goldstein, 14 August 1961, B.G.-U.S. Govt.General 20, RG 59, General Records of the Department of State, National Archives II, College Park, MD.
} 
Even more important to the United States was British Guiana’s geographical proximity to important Latin American nations, specifically Venezuela and Brazil. The United States AntiCommunist Campaign Task Force determined in 1958 that communist party membership in Venezuela was 20,000 and the nation was the primary target for communist subversives in Latin America. ${ }^{56}$ After the Cuban Revolution in 1959, Venezuela harbored the largest and most active communist party in the hemisphere outside of Cuba and Venezuelan communist party members held a considerable number of leadership positions within the international communist movement. ${ }^{57}$ In the early 1960s, Venezuela was the primary Latin American destination for private capital flowing from the United States by a considerable margin. ${ }^{58}$ By 1962 the Venezuelan Communist Party had embraced armed struggle as a vehicle for social change, and eastern Venezuela, which had been the point of entry for previous subversive activity, became strategically crucial once again. ${ }^{59}$ Thus, the Venezuela-British Guiana border was a point of concern for the United States making British Guiana invaluable to the overarching geo-strategic imperatives of the United States, especially in light of Cuba's active exportation of revolution in Latin America. ${ }^{60}$

Venezuela presented an additional problem for Great Britain. As noted earlier, the Essequibo region, encompassing the border between British Guiana and Venezuela had been contested since the mid-nineteenth century. The dispute was temporarily resolved with American

\footnotetext{
${ }^{56}$ Mr. Stevenson’s Substantive Reporting, 23 June 1961, Visits to L.A. (Stevenson Trip) ARA Files 1961, RG 59, General Records of the Department of State, National Archives II, College Park, MD.

${ }^{57}$ Charles D. Ameringer, The Democratic Left in Exile: The Antidictatorial Struggle in the Caribbean, 1945-1959 (Coral Gables, FL: University of Miami Press, 1974), 179; Thomas C. Wright, Latin America in the Era of the Cuban Revolution (Westport, CT: Praeger, 2001), 52.

${ }^{58}$ Venezuela ARA Files, Box 2, RG 59, General Records of the Department of State-Bureau of Inter-American Affairs, Subject Files of the Assistant Secretary1959-1962, Lot 62D418, National Archives II, College Park, MD. ${ }^{59}$ Wright, Latin American in the Era of the Cuban Revolution, 52; Ameringer, The Democratic Left in Exile, 156158.

${ }^{60}$ Memorandum from U.S. Information Agency to Department of State, 31 December 1958, RG 59, General Records of the Department of State, National Archives II, College Park, MD.
} 
mediation in 1895; however, Venezuela never fully accepted the decision and the dormant dispute threatened to explode once the colony was granted independence. ${ }^{61}$ The British government could not withdraw from the colony in a dignified manner if that withdrawal meant an immediate conflict with its neighbors. The small Guianese security force would be insufficient to protect the new nation's sovereignty if Venezuela pressed its claim to Guianese territory ${ }^{62}$ Ultimately, the resolution of the Venezuelan claim prior to independence was achieved through a complex diplomatic dynamic involving contentious behind the scenes deals between the United States and Great Britain. The Johnson Administration used its close relationship with Venezuela as leverage to convince the British to station troops in British Guiana after independence. American officials agreed to convince the Venezuelans to forego their claim in return for a temporary British military presence in British Guiana. British officials, however, were offended by what they perceived as blackmail by the United States. ${ }^{63}$ Despite British anger over the American suggestion, they agreed to the arbitration and a relatively cooperative dynamic continued between Great Britain and the United States in coordinating policy toward British Guiana.

Considerably more threatening to Anglo-American geo-political strategy was news that claimed Cuban arms were flowing through British Guiana into Venezuela and Brazil. Brazil, the largest nation in Latin America, was long thought to be on the verge of asserting itself as a global power. Brazil's stability was essential for the United States hemispheric strategy during the Cold War. As with Venezuela, Brazil’s shared border with British Guiana was a region of instability

\footnotetext{
${ }^{61}$ TNA, FO 371/179146, General Records of the American Department, Note from Sir Patrick Dean to Jack Rennie, 2 August 1965.

${ }^{62}$ TNA, FO 371/179146, General Records of the American Department, Note from Sir Patrick Dean to Jack Rennie, 2 August 1965; TNA, FO 371/179146, General Records of the American Department, Note from Jack Rennie to Sir Patrick Dean, Brief on British Policy in Guiana 2, 31 August 1965.

${ }^{63}$ TNA, FO 371/179146, General Records of the American Department, Minute by S. W. Martin to Foreign Office.
} 
and subversive activity. According to a Washington Daily News report on August 7, 1963, arms and ammunition were being smuggled from Cuba through British Guiana into Venezuela and Brazil. The sources said that the supplies were delivered by planes using dirt landing strips near the Venezuelan and Brazilian borders. ${ }^{64}$ While there is no evidence that the Soviet Union was directly assisting the PPP, Soviet assistance could have reached the colony with Cuba acting as intermediary. Relations between Jagan and the Castro government were limited; however, it is significant that Jagan openly pursued closer ties with the Cuban government and welcomed Cuban assistance whenever it was available. The United States could not easily dismiss these overtures as insignificant when developing policy during the Cold War. Thus, the Kennedy and Johnson administrations concluded that the threat posed by a Jagan-led PPP government aligning with Cuba, and by default with the Soviet Union, was legitimate. Consequently, American officials applied diplomatic pressure, engaged in economic sanctions and covert action, and staved off the British attempt at granting independence, until a more suitable government could be established in Georgetown.

Although it is generally advisable for historians to avoid engaging in counterfactual arguments; it is worth pausing for a moment to consider what might have happened. When evaluating the American fear of communist subversion in British Guiana, it is critical to contextualize the Cold War imperatives involved in the decision making process in the United States, and to a lesser extent Great Britain. In 1967 Che Guevara led a small band of rebels through Bolivia in an attempt to foment Cuban-style revolution in the country as the precursor to

\footnotetext{
${ }^{64}$ Thomas L. Hughes to William Burdett. General Records of the Department of State: Bureau of Inter-American Affairs, Office of Director of Caribbean Countries Records Relating to British Guiana 1957-74, POL-12-Political Parties-PPP (BG) RG 59, Records of the Department of State, Subject Numeric Files, National Archives II, College Park, MD.
} 
a continental-wide communist revolution. Historians have generally agreed that Bolivia was a poor choice for Guevara to begin. ${ }^{65}$

What if British Guiana had been granted independence under a Jagan led PPP government friendly to Cuba? Geographically, politically, and ideologically, an independent Guyana would have provided a much more advantageous starting point for advancing the Cuban revolutionary strategy across the continent than Bolivia. Politically, a Jagan led government may have been supportive or willing to turn a blind eye to Cuban activities. Cuban arms likely were already smuggled through British Guiana, even while the British maintained a colonial presence. In the absence of British oversight, under considerable stress to counter the PNC and attempts by the United States at subversion, and with an explosive border dispute to the west; Jagan would likely have increased his ties to the Castro regime in Cuba to maintain control of the country. The Cubans would have had a supportive government, albeit with a nominally stable populace, on mainland South America through which they would have had access and jungle cover to infiltrate Venezuela and Brazil. The proximity of communists in Venezuela and northeastern Brazil would have offered a springboard for expanding the revolution. The acquisition of Atkinson Airfield would have been a boon for the communist movement as well as an immense ideological loss for the United States. Additionally, instability in the far more economically relevant nations of Venezuela and Brazil would have been an ideological victory of far more consequence than a few unsupported rebels traversing the mountains of tiny Bolivia. While this scenario involves a considerable amount of speculation, it also accentuates the intricate frailty and uncertainty of South America in the 1960s. This is precisely why the United States was compelled to confront every perceived threat in the region as crucial to the nation's interest. It is

${ }^{65}$ Jon Lee Anderson, Che Guevara: A Revolutionary Life (New York: Grove Press, 1997), 680-682, 716,767. 
exactly the possibility of such a scenario that led the United States to fear what was at the time a possibility. $^{66}$

\section{Economic Considerations}

Great Britain was aware of Jagan’s communist ideals and his attempts to court Cuba, as well as Eastern bloc nations; however, the British were more concerned with British Guiana’s economic viability than of communist subversion. The British exerted considerable effort to ensure that capitalist investment would continue to flow into British Guiana after independence. Booker Brothers, the primary investor in the colony, was confident that Jagan was best suited to lead an independent government in British Guiana. ${ }^{67}$ The American based Reynolds Metals Company, one of the largest aluminum companies in the world, had considerable investments in Guianese bauxite, which it supplied to the United States, which needed the raw materials to sustain the Cold War military buildup. Walter Rice, Vice President of Reynolds Metals, became concerned in June 1962 when he learned that Jagan had been in contact with Poland and other Eastern Bloc countries attempting to broker trade agreements for Guianese bauxite. Jagan’s alleged dealings were predicated on the nationalization of some or all of Reynolds Metal’s holdings in British Guiana. ${ }^{68}$ British concerns over the prospect of Jagan nationalizing private capital were tempered, despite Jagan’s intentions, because of the significant cultural value East Indian farmers placed on the rights of private property. The British concluded that Jagan could never pursue government ownership of private property without losing his base of political

\footnotetext{
${ }^{66}$ It is worth noting that Eric Williams, the Prime Minister of Trinidad and Tobago feared the possibility of Jagan permitting communist subversives to make British Guiana a staging point for forays in the hemisphere. See: Colin A. Palmer, Eric Williams and the Making of the Modern Caribbean (Chapel Hill: The University of North Carolina Press, 2006), 210-211.

${ }^{67}$ Memorandum of Conversation, Washington 17 March 1962, FRUS 1961-1963, 12: 273.

${ }^{68}$ Walter Rice to Griffith Johnson, 19 June 1962, Br. GU.-Mining and Minerals 6.7, RG 59, Records of the Department of State, National Archives II, College Park, MD.
} 
support. ${ }^{69}$ Ultimately, American preoccupation with the PPP’s foreign policy and British Guiana’s significance as a crucial part of the regional Cold War strategy, trumped British analysis of domestic programs and resulted in a persistent fear of Jagan’s communist leanings. American pressure combined with Jagan's ineffective leadership culminating in Anglo-American support for Burnham.

\section{Contention and Cooperation in the Anglo-American Alliance}

The United States and Great Britain envisioned a stable, pro-Western government being established in British Guiana after independence; however, there was not a consensus on how to achieve these aims. Thus, the United States and Great Britain exerted a considerable effort to formulate a coordinated policy in British Guiana before independence was given to the Guianese. The level of cooperation in developing a coordinated British Guiana policy between Great Britain and the United States cannot be understated. It is perhaps best exemplified in an internal memorandum regarding the post-independence stationing of British troops in Guyana, which stated: "In reaching this difficult decision, we took fully into account United States views as expressed by Mr. Bundy (your telegram under reference) and again by Mr. Rusk in his talks with the Colonial Secretary.”70 The same was true of policymakers in the United States. American policy considered British imperatives at every turn. ${ }^{71}$

\footnotetext{
${ }^{69}$ Memorandum of Conversation. East Indian Comments on BG Scene, General Records of the Department of State: Bureau of Inter-American Affairs, Office of Director of Caribbean Countries Records Relating to British Guiana 1957-74, POL-Political Affairs Memcons (BG), RG 59, Records of the Department of State, National Archives II, College Park, MD.

70 TNA, FO 371/179146, General Records of the American Department, Note From Foreign Office to Washington, 24 November 1965.

${ }^{71}$ Gordon Knox to William Burdett, Contingency Planning for British Guiana, 2 October, 1962, Department of State, Br. Guiana Briefing Papers 1.8, RG 59, Records of the Department of State, National Archives II, College Park, MD.
} 
Initially, the United States deferred to British strategy in British Guiana and in mid-1961 President John F. Kennedy outlined a strategy for working with Cheddi Jagan. The decision was founded on the idea that the British should take the lead in formulating policy in their colony, despite its geographic proximity to the United States. The State Department indicated that the United States government was pursuing a: "whole hearted, across the board effort to work with Cheddi Jagan.,72 The American policy was the result of a careful consideration of British concerns and the desire to have a coordinated policy with British officials. The necessity of maintaining a strong Anglo-American alliance compelled the United States to attempt to work with Jagan, despite strong misgivings about his intentions once independence was granted. Jagan’s foreign policy decisions undermined this policy by June 1962, but the significance of working within a cooperative framework remained.

The brief for Prime Minister Harold MacMillan’s visit with President John F. Kennedy at Birch Grove in June 1963 exemplifies the importance of United States imperatives to British policy. Likewise, it shows how Great Britain played an active part in the formation of United States policy in an effort to create a functional alliance. MacMillan’s talking points acknowledge the fact that the British had no strategic interest in British Guiana and their overriding goal was to withdraw from the colony as soon as possible. The British withheld independence despite their general approval of Jagan and were willing to work with the United States to establish an alternative government under Burnham to quell American anxieties. ${ }^{73}$ MacMillan sought to appease both British and American interests in British Guiana. The overall significance of British

\footnotetext{
${ }^{72}$ William Tyler to The Under Secretary: The United States Policy Towards British Guiana, 1 December 1961, Br. Guiana-US Position Papers (AID) 2.7, RG 59, Records of the Department of State, National Archives II, College Park, MD.

${ }^{73}$ TNA, CO 1031/4866, Records of the West Indian Department, Brief for Prime Minister's Talks with President Kennedy: British Guiana: Talking Points, June 1963.
} 
Guiana to relations between the nations was acknowledged in the Joint Assessment by U.S. and British Officials that was agreed upon during Kennedy and Macmillan’s talks. The assessment made clear that Anglo-American relations would suffer considerably if a communist government emerged in British Guiana after independence. ${ }^{74}$ Therefore, Great Britain framed its decolonization policies within the broader context of United States Cold War strategy. Simultaneously the United States, while pushing its geo-strategic objectives in British Guiana, accepted that British imperatives in the colony would inevitably impact the direction of policies made in Washington.

The appropriate level of intervention within the British Guianese domestic scene was an area of frustration and, occasionally, contention between British and American policymakers. John Henning, Colonial Office attaché at the British embassy in Washington, joked: “...it is difficult for [American policymakers] to realise how impotent the colonial power is. This reluctance is traditional: it is somewhat of a national heresy for Americans to believe that the colonial power against which their patriots rose and battled so heroically was really rather powerless.” He continued: “...you would think that a nation that resented imperial legislation as vigorously as they did would be among the first to recognise the consequences of legislating by Order in Counsel over the headx $\{$ sic $\}$ of Dr. Jagan...Knox admits this, but suspects that there is something wrong in a world in which what was good for Sam Adams must be good for Cheddi Jagan!"75 This tongue in cheek statement hints at the challenge for the two nations. The relative power of Great Britain in controlling the events within their colony was considerably less than what the United States imagined. The United States expected British support of American Cold

\footnotetext{
74 TNA, CO 1031/4866, Records of the West Indian Department, Analysis prepared jointly by U.S. and British officials meeting in London, 25-27 June 1963.

75 TNA, CO 1031/4866, Records of the West Indian Department, Note from John Hennings of British Embassy, Washington D.C. to Ambler Thomas of Colonial Office, 15 February 1963.
} 
War policies and Great Britain backed the United States as much as was possible; however, decolonization presented a challenge to the special relationship.

The geographical significance of British Guiana for the United States tempted them to pursue policies which were more aggressive than what Great Britain was willing to engage in. The British, adjusting to the new international environment of the post-World War II era, were reluctant to intervene too aggressively in the decolonization process in their own colony. Additionally, the British were restrained by the practical realities of decolonizing an empire. Colonial officials needed to understand and consider the local conditions which varied in each colony and ensure that the incoming government was prepared to maintain stability when the British withdrawal from the colony was final. Finally, the entire decolonization process was complicated by Great Britain’s need to incur minimal financial drain as they liquidated the empire. For both ideological and practical reasons, the United States and Great Britain were never entirely in agreement about how to best decolonize British Guiana and were each forced to make concessions to assure the success of their partnership.

The United States offered financial aid, diplomatic pressure, and vocal support for British policies in the international community as a means of generating compromise with British officials. Deputy Director of British Commonwealth and Northern European Affairs, Gordon Knox, explained to Assistant Secretary of State, William Burdett that: "If the U.S. could promise substantial aid, e.g., not less than $\$ 15,000,000$ per year HMG would be inclined to accede to our wishes... and if the British felt that Burnham would get arms from the USG or from agencies of the US government....it might prefer to postpone its departure temporarily. If the British felt that their wishes would be heeded by the U.S. with regard to certain other problems in other parts of the world...in return for British compliance to U.S. wishes in BG, the British Government might 
strive more energetically to bring about in BG a pre-independence PR election." ${ }^{76}$ Thus, the delay of independence for British Guiana and the British institution of proportional representation in the colony before the December 1964 election can be seen largely as a successful negotiation between the United States and Great Britain and between the imperatives of Cold War and decolonization.

British and American imperatives coalesced as it became clear that a Cheddi Jagan led PPP could not establish domestic stability in British Guiana. It is critical to acknowledge that Jagan's inability to control the civil services, and thus maintain order in the colony, weighed on the British decision to support Burnham. It is not coincidental that the determination by the British that Burnham could maintain the loyalty of the police force preceded their decision to compromise with the United States. ${ }^{77}$ It is also critical to acknowledge that British and American officials had come to a near agreement about what the PPP's foreign policy designs would be for the post-colonial government. Both Great Britain and the United States were certain that Jagan would move to establish a Castro-styled communist government after independence. They disagreed only in that the United States felt that intervention was necessary to keep Jagan from succeeding, while British officials thought that internal opposition in British Guiana may be strong enough to impede the PPP's plans. ${ }^{78}$ Thus, Burnham's adroit diplomacy, which addressed specific American concerns about British Guiana’s post-colonial foreign policy, gave the AngloAmerican alliance a way to keep the colony from establishing a communist government. Burnham explained to American Consul, Delmar Carlson, that once the PNC assumed power, he

\footnotetext{
${ }^{76}$ Gordon Knox to William Burdett. Contingency Planning for British Guiana, 2 October, 1962, Br. Guiana Briefing Papers 1.8, RG 59, Records of the Department of State, National Archives II, College Park, MD.

${ }^{77}$ Gordon Knox to William Burdett, Contingency Planning for British Guiana, 2 October, 1962, Br. Guiana Briefing Papers 1.8, RG 59, Records of the Department of State, National Archives II, College Park, MD.

78 TNA, CO 1031/4866, Records of the West Indian Department, Analysis prepared jointly by U.S. and British officials meeting in London 25-27 June 1963.
} 
would not recognize the Soviet Union or Castro, he would cut trade with Cuba, and British Guiana would apply to join the Organization of American States (OAS). ${ }^{79}$ Supporting Burnham would provide the internal stability necessary to fulfill the British objective of stabilizing the Guianese government prior to independence and concurrently absolve the United States of the worry of a communist government springing up in a geographically crucial region of the world.

The Anglo-American strategy was not without its potential problems; however, fear of post-colonial political oppression in British Guiana was less of a concern to British and American policymakers than addressing strategic concerns. British officials were aware that the PNC would seek to suppress the PPP and its supporters once they colony had achieved independence. Colonial Governor Richard Luyt was equally disturbed at the notion that the PNC would not address racial imbalances in the civil services and thus further oppress East Indians in British Guiana. ${ }^{80}$ However, post-colonial pitfalls were judged to be less of a risk than supporting the Jagan-led government. Luyt concluded that the PPP had proven itself incapable of governing British Guiana. The Jagans could not hope to assert their authority over a predominantly AfroGuianese police force. Additionally, the PPP foreign policy assured that British Guiana would not receive American development aid after independence if the Jagans were in power. Finally, instability would be assured in the colony and the PNC and UF in opposition would be capable of undermining the government because of their supporters in Georgetown. ${ }^{81}$ Thus, British decolonization imperatives began to align with American goals in British Guiana and an AngloAmerican compromise became possible for the colony.

\footnotetext{
${ }^{79}$ Delmar Carlson to State Department, 11 September 1964, FRUS 32:389.

${ }^{80}$ TNA, CO 1031/4407, Records of the West Indian Department, Note by West Indian Department B: British Guiana: After the Elections, November 1964.

${ }^{81}$ TNA, CO 1031/4407, Records of the West Indian Department, Note by West Indian Department B: British Guiana After the Elections, 30 November 1964.
} 
The United States applied persistent pressure on Great Britain to support Burnham and once obtained, that support proved decisive. Burnham was the leader British and American officials were forced to work with, and certainly not the leader with whom they desired to work. State Department records indicate that the United States made an ongoing effort to find a viable anti-communist alternative to Jagan to lead the East Indians. ${ }^{82}$ Great Britain and the United States made pragmatic choices in British Guiana based on a strategically poor set of possibilities. Burnham and Jagan, as will be explored in the following chapter, played a crucial role in determining British Guiana’s destiny. However, local conditions in British Guiana worked against the establishment of a PPP government in British Guiana.

Ultimately, Great Britain and the United States coordinated their policy based on mutual interests in British Guiana. Each pursued individual interests, while being cognizant of the imperatives of its ally. The United States was primarily concerned with waging the Cold War, a struggle occurring most often and intensely in previous European colonies. Great Britain, in turn, was engaged heavily in disassembling its erstwhile empire, an exercise never divorced from its Cold War implications. Despite what was at times a contentious relationship, the two nations forged a decolonization policy which, at the time, achieved both nations' goals in the region. The British established an independent government in British Guiana that maintained stability after British troops and administrators left, and the United States set in place a leader willing to work within an American approved Cold War framework. The consequences for the Guianese people were less positive. Burnham implemented an increasingly repressive government, supported by fraudulent elections and American aid. ${ }^{83}$ Thus, the United States and Great Britain won a

\footnotetext{
${ }^{82}$ Memorandum from Gordon Knox to Everett Melby, March 11, 1963, RG 59, Records of the Department of State, National Archives II, College Park, MD.

${ }^{83}$ Rabe and Spinner both provide excellent descriptions of the post-independence government in Guyana.
} 
complex Cold War victory in British Guiana. Having established British and American objectives in British Guiana, the following chapter will elaborate on the role of the Guianese themselves in determining the actions taken by the Western Powers. 


\section{Chapter 4: Participants in the Cold War: The Impact of the People’s Progressive Party's Foreign Policy in British Guiana}

Since 1898 the United States has held a dominant position in the Caribbean and has helped define Western inter- hemispheric relations. Throughout the twentieth century, American strategic and economic imperatives in the region were advanced through frequent and diverse forms of intervention. Through the Good Neighbor Policy, Presidents Herbert Hoover and Franklin Roosevelt attempted to minimize the role of direct intervention during the 1930s and 1940s. However, heightened international tensions during the Cold War provided the impetus for a return to interventionism in the Caribbean with the aim of preserving American ideals and security. The previous chapter discussed the strategic objectives of the United States and Great Britain in British Guiana. This chapter will narrow the focus and examine how Guianese leaders made foreign policy decisions which impacted American and British policy toward British Guiana. Specifically, the chapter will show how the People’s Progressive Party (PPP) squandered an opportunity to work with the United States between August 1961 and June 1962, effectively ending its chances of being the party that would lead British Guiana to independence. Additionally, this chapter will briefly discuss how and why the United States and Great Britain determined in June 1963 to eliminate the PPP as the party of the government in British Guiana before the transfer of power.

Policymakers in the United States perceived the growing power of the Soviet Union after World War II as a serious threat to the region that required an increased assertion of American influence to thwart international communist subversion. The United States government had determined to tighten security in its backyard. However, despite the relatively diminutive size of Caribbean nations, and the strength of the United States, it is critical not to underestimate the 
impact of less powerful hemispheric leaders on policy in the United States. Some adroit hemispheric officials successfully pursued independent policies in the shadow of their neighbor to the north, while the others wrought their own demise by failing to engage the United States with effective diplomacy. This chapter will explore the failure of the Cheddi and Janet Jagan led PPP government in British Guiana from 1961-1963. It will explain the PPP’s failure as a result of Jagan's inability to conduct an efficient foreign policy, specifically in relation to the United States.

\section{The Influence of the Cold War on Interpreting Decolonization in British Guiana}

The historiography of British Guiana speaks to the issue of racial politics and the important role played by Great Britain and the United States in determining the course of Guianese independence. While several authors have made a connection between internal politics and foreign intervention, the crucial role played by the colony's political leadership in influencing Anglo-American foreign policy has been largely overlooked. Domestic politics in British Guiana increasingly degenerated into racially polarized blocs after the PPP split in $1955 .{ }^{1}$ The division of the party into two distinct political-racial constituencies, East Indian and AfroGuianese, is well documented. Both Jagan’s PPP and Forbes Burnham’s People’s National Congress (PNC) struggled to maintain their ethnically diverse memberships, which had led to domestic success of the PPP in the early 1950s. Despite their efforts, Guianese politics diverged along racial lines and both men sought to enhance the façade of a multi-racial appeal of their parties even as their political campaigns and policies became more singularly focused on

\footnotetext{
${ }^{1}$ Stephen G. Rabe, U.S. Intervention in British Guiana: A cold War Story (Chapel Hill: The University of North Carolina Press, 2005), 54-55.
} 
appealing to their respective racial communities. ${ }^{2}$ Jagan and Burnham realized that regardless of which party controlled the government at independence, social conflict was a distinct possibility. They also understood that Great Britain was unlikely to grant independence to the colony until the Guianese established a government capable of suppressing racial violence and sustaining domestic stability. Nevertheless, the colony remained politically divided into two racial constituencies, a trend Jagan and Burnham perpetuated. Jagan enjoyed a slight edge in popular support within the colony; however, whoever could successfully court the third constituency, interested foreign powers, would determine the fate of the colony. Jagan's failure to effectively engage in pragmatic diplomacy coupled with Burnham's ability to placate to the interests of the United States resulted in greater Anglo-American support for the PNC, and thus won Burnham the leading role in a newly independent Guyana.

Scholars have traditionally explained the Jagans’ struggle in British Guiana as a David fighting against the Goliaths of the United States and Great Britain. They attribute the PPP loss of power to the Central Intelligence Agency's (CIA) covert subversion, primarily through financing Guianese opposition under the cloak of international labor organizations such as the American Federation of Labor (AFL), Congress of Industrial Organization (CIO), and InterAmerican Regional Organization (ORIT). Jagan is often portrayed as a victim of the Cold War, a phrase that he himself used to describe the plight of his nation. ${ }^{3}$ Academics such as Stephen Rabe and Thomas Spinner have suggested that the Kennedy and Johnson Administrations took advantage of endemic, but previously contained, racial tensions in Guianese society to

\footnotetext{
${ }^{2}$ Myriad important works speak on the issues of racial politics within Guianese society. See: Rabe, U.S. Intervention in British Guiana; Leo Despres, Cultural Pluralism and Nationalist Politics in British Guiana (Chicago: Rand McNally and Company, 1967); Cheddi Jagan, The West on Trial: My Fight for Guyana's Freedom (New York: International Publishers, 1966); Thomas Spinner, A Political and Social History of Guyana 1945-1983 (Boulder: Westview Press, 1984).

${ }^{3}$ Melby to Department of State, 4 December 1961, 741D.13/1-1862, RG 59 Records of the Dept of State, National Archives II, College Park, MD
} 
manipulate the domestic politics of the colony using the politics of racial discord. ${ }^{4}$ Thus, the Jagans would be defeated through isolation from the Afro-Guianese community and a loss of their multi-ethnic coalition. According to these interpretations, the United States government used the ensuing social unrest to pressure Great Britain into manipulating the electoral system of British Guiana as a way of achieving the desired outcome, a government fronted by Forbes Burnham. There is ample evidence to suggest that the United States maintained a consistent strategy of opposition to Cheddi and Janet Jagan in British Guiana between 1953 and 1966 and the British Colonial Office’s imposition of proportional representation on the colony was a transparent attempt to remove the Jagans through ostensibly legal means. ${ }^{5}$

Similarly, Richard Barnet sees developments in British Guiana as being the consequence of overzealous American anti-communism. Barnet is prescient in noting the complexity of relations between the United States and Great Britain in the Cold War world. He notes that the United States saw the decline of the British Empire as an economic opportunity; however, after World War II, American policymakers also viewed the drastically changing global power structure as a threat to their national security. The power vacuum in post-colonial regions, along with the increasing role of the Soviet Union and localized communist movements in developing areas, was specifically troubling to American officials. ${ }^{6}$ According to Barnet, the United States sought to improve their security by eliminating governments in the developing world which they deemed communist. He suggests a number of qualities that American policymakers looked for in making such a classification, such as nationalization of private industry, radical land reform,

\footnotetext{
${ }^{4}$ Rabe, U.S. Intervention in British Guiana, 30-31, 75-76, 103; Spinner, A Political and Social History of Guyana, ${ }^{5}$ Philip Agee, Inside the Company: CIA Diary (New York: Bantam Books, 1975), 416; Rabe, U.S. Intervention in British Guiana; Jagan, The West on Trial; Spinner, A Political and Social History of Guyana 1945-1983.

${ }^{6}$ Richard Barnet, Intervention and Revolution: The United States in the Third World (New York: The World Publishing Company, 1968), 106.
} 
autocratic trade policies, acceptance of Soviet or Chinese aid, and insistence on following an anti-American or non-aligned foreign policy. According to Barnet, the existence of these qualities in the third world was used to justify American intervention. ${ }^{7}$ Barnet effectively notes the dangers faced by American policymakers, who were overly rigid in their classification of emerging governments, when perceiving the world through a Cold War lens. Barnet concludes that the United States, when it feared a communist regime emerging in the developing world, would undermine or even pursue its expulsion. The PPP in British Guiana exhibited most, if not all, of Barnet's qualifications; however, explanations which attribute the demise of the Jagans in the 1960s solely to American intervention are incomplete. This chapter suggests that the PPP's foreign policy, in conjunction with American subversive activities, undermined the Jagans’ position in British Guiana.

The Jagans were career politicians, who although adept at building inter-Guianese political coalitions, failed at foreign policy. Despite the corrosive dynamic of American opposition and Jaganite irritation, the PPP maintained a position of dominance in British Guiana into the 1960s. The PPP's victory in the August 1961 elections ushered in the decisive period of pre-independence politics in British Guiana. In this critical moment, Cheddi Jagan and the Party's leadership squandered the opportunity to become a viable option to lead the colony to independence. The inability of the PPP to appreciate the degree to which the United States set the Cold War agenda for intra-hemispheric relations contributed to the party’s failure. More importantly, Jagan's failure to accurately assess the consequences of concurrent events in the Caribbean, especially in Cuba, led to a failed foreign policy. Thus, despite the Jagans knack for

\footnotetext{
${ }^{7}$ Ibid, 9-10.
} 
obtaining electoral victories in British Guiana, Cheddi Jagan could not retain enough support in Great Britain to overcome the effects of American opposition.

\section{A Comparison of Latin American Nationalist Leaders During the Early Cold War}

It is enlightening to compare Jagan to other regional leaders who did develop effective relationships with the United States, and to examine the dissimilar trajectories their political careers followed as a result of that association. Kyle Longley and Eric Roorda have explored how Jose Figueres in Costa Rica and Rafael Trujillo in the Dominican Republic were able to pursue nationalist policies and resist United States domination in a heightened period of American intervention. Figueres even managed to work with leftists and communists in Costa Rica to achieve his domestic goals. ${ }^{8}$ Their work lays the groundwork for political studies of local Caribbean leaders during the mid-twentieth century. Figueres and Trujillo thrived primarily as a result of their ability to conduct successful foreign relations with the United States due to several key advantages which they utilized effectively. Four key distinctions can be made between the Jagans and Figueres and Trujillo.

First, Figueres and Trujillo were able to take advantage of a positive historical relationship with the United States. Longley describes Figueres as having benefited from a legacy of amicable exchange wherein Costa Rica had established itself as a supporter of the United States during major international crisis; including declaring war on Japan in 1941before the United States congress officially approved hostilities. ${ }^{9}$ Similarly, Trujillo survived considerable international opposition as well as resistance from the State Department to a great

\footnotetext{
${ }^{8}$ Kyle Longley, The Sparrow and the Hawk: Costa Rica and the United States During the Rise of Jose Figueres (Tuscaloosa: The University of Alabama Press, 1997); Eric Paul Roorda, The Dictator Next Door: The Good Neighbor Policy and the Trujillo Regime in the Dominican Republic, 1930-1945 (Durham: Duke University Press, 1998).

${ }^{9}$ Longley, The Sparrow and the Hawk, 2, 33.
} 
degree because of relationships developed during his time working with the United States Marines. ${ }^{10}$ Jagan, and indeed British Guiana itself, did not inherit the benefits of previously successful political ties to the United States. The United State generally ignored British Guiana until international labor unions alleged the existence of communist elements in the colony in the mid-1950s. Thus, Guianese political leaders had no political capital to draw on for support from the United States, while they attempted to progress toward independence at odds with several key American ideological positions.

Secondly, Figueres and Trujillo benefited from the support of their respective militaries. Trujillo initially came to power as head of the Dominican military and he maintained that role until his demise in 1961. Despite opposition from Rafael Calderon and small armed insurrections, Figueres was never in danger of losing control of the armed forces and came to power in part as the consequence of armed revolt. ${ }^{11}$ Jagan, however, never controlled the armed services in British Guiana and as a result was incapable of asserting control over the colony when crisis occurred. Janet Jagan's resignation as head of the civil services in 1964 is characteristic of the PPP's relationship with the mostly Afro-Guianese police force, which took its orders from the political opposition, namely, Forbes Burnham. ${ }^{12}$ Officials in the United States placed a considerable importance on the maintenance of stability in the Caribbean, especially during the Cold War, and the PPP was powerless to assert control without the aid of British troops. $^{13}$

\footnotetext{
${ }^{10}$ Roorda, The Dictator Next Door, 21-22, 45.

${ }^{11}$ Longley, The Sparrow and the Hawk, 67-70.

12 Jagan, The West On Trial, 359.

${ }^{13}$ Rabe, U.S. Intervention in British Guiana, 91; Roorda, The Dictator Next Door, 231; Telegram from the Department of State to the Embassy in the United Kingdom, 19 February 1962, FRUS 1961-1963, 12: 264.
} 
Thirdly, and most importantly, the United States demanded a firm commitment to anticommunism in the Caribbean during the Cold War. Figueres and Trujillo were adamant anticommunists, while Jagan held an ideological position opposite to that of the United States, supporting communist nations and praising the Cuban Revolution. Trujillo avoided repercussions for countless repressive measures and violence because he advanced the geo-strategic imperatives of the United States, assuring stability in his small nation. ${ }^{14}$ Figures initially obtained support from the United States after Calderon failed to discern the shift in American policy toward opposing left-wing politicians after the Second World War. ${ }^{15}$ American officials were confused about Figueres' ideology. Indeed, he was classified at times as authoritarian and socialist, but he remained clearly anti-communist. ${ }^{16}$ His vocal commitment to combat communism provided him with the leeway to enact domestic social reforms which destroyed other Caribbean leaders, specifically Jacobo Arbenz in Guatemala. Figueres nationalized banks and imposed taxes on the wealthy, though even in pursuing domestic reform Figures was aware of the need to work within a framework acceptable to the United States. Confrontation with the influential United Fruit Company was the impetus for the American supported overthrow of Arbenz, and Figueres wisely avoided challenging United Fruit in Costa Rica. ${ }^{17}$ Jagan’s domestic program was moderately reformative; however, when coupled with his vocal support of communism, it was unacceptable to the United States. The determining factor in American opposition to the PPP was the Jagans' vocal support of communism and their pursuit of a foreign policy which seemed to support their communist ideology.

\footnotetext{
${ }^{14}$ Roorda, The Dictator Next Door, 192-193, 228-231.

${ }^{15}$ Longley, The Sparrow and the Hawk, 40.

${ }^{16}$ Ibid, 59.

${ }^{17}$ Ibid, 87-88.
} 
Finally, Figueres and Trujillo maintained the support of key elements within the United States. Figueres was close to liberal democratic groups and labor leaders, such as Robert Alexander and Serafino Romualdi. Trujillo had ties to the United States military and individuals close to the White House such as Joseph E. Davis, who was a close friend of President Roosevelt and Secretary of State Cordell Hull. ${ }^{18}$ Both men were willing to placate the American public. Trujillo named highways after George Washington and the United States Marine Corps and Figueres made frequent references to symbolically connect Costa Rica and the United States. ${ }^{19}$ Tellingly, Romualdi, who was president of the AFL and CIO backed Inter-American Regional Organization (ORIT), was closely connected to the Kennedy White House, and was one of Jagan’s staunchest opponents. Figueres condemned radical anti-American policies during a speech in Havana, while Jagan continually supported the Cuban Revolution, at one point referring to Castro as the greatest liberator of the twentieth century and calling on his people to help defend the Cubans, with arms if necessary. ${ }^{20}$ The disparity between Figueres, Trujillo and Jagan can best be summarized in their own words. Jose Figueres angered the United States when he publically stated: “I know. I am a citizen of a 'banana republic'.”21 Notwithstanding the irritation of American officials, the statement provides a key insight into Figueres’ ability to thrive as a political figure during the Cold War. He understood his political reality, made concessions when necessary and thus freed himself to pursue an independent course of action elsewhere. Conversely, Jagan was quoted in December 1961 as stating: “We don’t want to get

\footnotetext{
${ }^{18}$ Ibid, xii, 122; Roorda, The Dictator Next Door, 76.

${ }^{19}$ Longley The Sparrow and the Hawk, xii; Roorda, The Dictator Next Door, 117-118.

${ }^{20}$ Longley, The Sparrow and the Hawk, 153-154; Melby to Department of State, 29 June 1962, 741d.00/6-2962, Central Decimal Files Box 1668, RG 59, Records of the Department of State, National Archives II, College Park, MD.

${ }^{21}$ Longley, The Sparrow and the Hawk, 132.
} 
involved in the Cold War. We have been victims of it." ${ }^{22}$ On the surface his statement may appear benign; however, it belies Jagan's critical flaw as a politician. He was incapable of comprehending the reality of his tenuous position as the proposed leader of a soon to be independent Caribbean nation. Cheddi Jagan attempted to operate in an ideological world in which he did not have to confront real world political situations. Whereas Figueres and Trujillo acknowledged and manipulated their key political reality, namely, that the United States was the ultimate authority in the Western Hemisphere, Jagan either did not appreciate it until it was too late, or he ignored it. Regardless, his inability to establish an effectively functioning foreign policy based on a realistic assessment of his political footing doomed him to be the victim that he claimed to be.

\section{Contextualizing the Impact of American Subversion in Undermining the PPP Government}

This chapter suggests that the PPP’s foreign policy was the determining factor in framing American strategy in British Guiana; however, it would be remiss to overlook the effect of momentum on bureaucratic politics, in this instance the role of the AFL-CIO and the CIA. Stephen Rabe notes that American labor leaders, such as Alexander, Romualdi, and Jay Lovestone, were actively involved in Guianese politics throughout the 1950s, likely operating with covert funding from the CIA. The CIA began actively pursuing a strategy of spreading racial domestic unrest to diminish support for the PPP, which impacted events as early as the end of the 1950s and certainly by the early 1960s. Additionally, Rabe is prescient in noting that Alexander, Romualdi, and Lovestone had close access to Presidents Kennedy and Johnson, which presented them an opportunity to influence policymaking in Washington and advance an

\footnotetext{
${ }^{22}$ Melby to Department of State, 4 December 1961, 741D.13/1-1862, RG 59 Records of the Dept of State, National Archives II, College Park, MD
} 
anti-PPP agenda. ${ }^{23}$ However, the Jagans' decision to persistently seek cultural, economic, military, and especially ideological, associations with communist nations reinforced American opposition and compounded the erosion of the PPP's position in the colony as a consequence of the CIA's manufactured internal racial discord. The foreign policy of the PPP undermined Jagan and perpetually antagonized consecutive administrations in the United States. Thus, it was the PPP foreign policy, not bureaucratic inertia, which led to the decision of the United States government to subvert Jagan .

\section{PPP Policy From 1953 to 1959}

British Guiana was first granted internal self-government in April 1953 after a national election in which the PPP won a landslide victory. The Jagans overestimated the strength of their position, however, and pursued a course which failed disastrously and would be indicative of their missteps over the ensuing decade. The Jagans chose to combine an agenda of social reform with a vocal espousal of Marxist rhetoric. In less than six months Great Britain suspended the constitution in British Guiana and reverted to direct control, fearing a communist takeover of the colony. ${ }^{24}$ The Jagans stubbornly refused to adapt to political realities, perhaps because they maintained the dominant position in Guianese politics. Other important members of the PPP did adapt to strategic realities and split with the party over the course of the ensuing decade. The most important rift in Guianese politics occurred when key members of the PPP split from the party in 1955, most of whom followed a faction led by Forbes Burnham.

\footnotetext{
${ }^{23}$ Rabe, U.S. Intervention in British Guiana, 56-57; For more on the relationship between American based labor unions and the CIA, specifically the use of the AFL-CIO as a tool to advance American interests, See: Matthew Connelly, A Diplomatic Revolution: Algeria's Fight for Independence and the Origins of the Post-Cold War Era (Oxford: Oxford University Press, 2002), 58-59, 165-167, 278.

${ }^{24}$ Rabe, U.S. Intervention in British Guiana, 48; Spinner, Political and Social History of Guyana, 43-44.
} 
The Jagans spent nearly a decade organizing and ascending within the Guianese political structure before the election in 1953. They interpreted their astounding victory as a confirmation that they were indeed representative of the Guianese people and increasingly infused their personal political beliefs into the governing of the colony, identifying the nationalist cause of the Guianese with the anti-colonial aspirations of other colonized areas of the world. More importantly, the Jagans proceeded with social reforms and sought to develop ties with left-wing governments. Decisions made in the immediate aftermath of the election came to the attention of international trade unions with ties to the United States government. Serafino Romualdi, InterAmerican Representative of the American Federation of Labor (AFL) derided the Jagans for importing what he called subversive literature over a number of years. In an article for the AFL's Free Trade Union News, Romualdi noted: "When Jagan came to power his first act was to repeal the [Anti-Subversive Literature] Bill.” The bill was the first of a number of controversial reforms passed by the PPP over the summer of 1953. Romualdi also thought it important to note that: “...two weeks after the elections which the PPP won, Mrs. Jagan went to Russia according to the newspapers.”25 British Colonial governor Alfred Savage had already suspended British Guiana’s constitution and reasserted direct control over the colony by the time Romualdi's concerns were heard in the United States. ${ }^{26}$ However, the Jagans maneuvers laid the basis for American suspicion of the PPP's intentions for British Guiana. The PPP would have to adapt politically to win the increasingly important third constituency in colonial politics.

Both Cheddi and Janet Jagan endured prison sentences in British Guiana in1954 for acts of civil disobedience. Cheddi Jagan violated a travel ban confining PPP members to Georgetown

\footnotetext{
${ }^{25}$ Mr. Christenson to Mr. Horowitz, 27 October 1953, 741D.00/10-2753, RG 59, Records of the Department of State, National Archives II, College Park, MD.

${ }^{26}$ Rabe, U.S. Intervention in British Guiana, 42.
} 
when he visited a branch of his dental surgery practice on the East Coast of Demerara on April 3 and was imprisoned until September 11. Janet was arrest a few days before her husband was released, for allegedly being in possession of a 'Secret' Police Riot Manual and organizing a political meeting. There is considerable debate over the severity of the Jagan's offenses. Cheddi Jagan in fact claimed that the riot manual was planted in his home and that the supposed political meeting his wife organized was nothing more than an Indian religious festival, known as a Bhagwat. ${ }^{27}$ Regardless of the minimal nature of their offenses, the Jagans continued to receive negative publicity, while their erstwhile ally, Burnham, organized a new strategy for obtaining power in British Guiana.

The suspension of the British Guianese government in 1953 because of British fear of a communist revolution and the ensuing repression against the party destabilized the PPP and by 1955 the party split into two factions, one led by Forbes Burnham, the other by the Jagans. The division of the PPP can be attributed primarily to two causes, an internal power struggle between the Jagans and Burnham for supremacy within the party and an ideological conflict over the future direction of the PPP. Burnham's faction defined themselves as moderate social democrats while the Jagans continued to espouse Marxists political ideals, though somewhat less fervently than prior to the British intervention in $1953 .{ }^{28}$ While somewhat tempered, the Jagans continued to espouse radical rhetoric in the aftermath of the split in the PPP. The political ideals of the Jaganite faction were elaborated on in a policy statement obtained by The Daily Chronicle. In December 1956 the United States Consul, A. John Cope, wrote to the State Department regarding this information. He interpreted the statement to be a confirmation of Jagan as "an

\footnotetext{
${ }^{27}$ Jagan, The West on Trial, 193-197.

${ }^{28}$ Spinner, Political and Social History of Guyana, 67-70.
} 
unrepentant Communist” who "remains steadfast in support of Soviet Communist policy.,29 When national elections were held in 1957, the Jaganite faction of the PPP resoundingly defeated the Burnham faction and re-affirmed its position as the primary political force in the colony. Burnham finalized his split with the party after the election by forming the PNC. The PPP exercised prudence in the first two years after the election and created the opportunity for the Jagans to work with the United States and potentially win the third constituency. Thus, despite the Jagans' radical rhetoric, they briefly showed signs of wanting to work with the United States, before the Cuban Revolution altered their perception of British Guiana’s political realities.

The PPP made several requests for loans from the United States from 1957-1959, and though the United States was generally unreceptive to Jagan’s overtures for financial assistance, relations began to improve, establishing a possible basis for future cooperation. ${ }^{30}$ State Department officials went as far as recommending the government work with Cheddi Jagan in July 1959, citing "responsible” behavior after the election in 1957.However, American officials remained skeptical of Jagan’s intentions and encouraged moderate cooperation, “without a great show of friendliness. ${ }^{31}$ Internal records indicate that Jagan impressed the officials with whom he met during his visit in July 1959. A summary of the meeting characterized him as: "personable, utterly charming, intellectually very bright, highly articulate, well informed and a most able narrator of his country's problems." Most importantly he was: "not see[n] to fit the description of Communist which has been applied to him.,32 It is unlikely that upper level administrators in the State Department shared these conclusions, considering Jagan did not meet with anyone above

\footnotetext{
${ }^{29}$ American Consul A. John Cope, Jr. to The Department of State, Washington, 28 December 1956, 741D.00/122856, RG 59, Records of the Department of State, National Archives II, College Park, MD.

${ }^{30}$ Cheddi Jagan to John F. Kennedy 16 April 1963, FRUS 1961-1963, 12:292.

${ }^{31}$ William Dale to Mr. White, 30 July 1959, BG 22/Visit of Jagan to U.S., RG 59, Records of the Department of State, National Archives II, College Park, MD.

${ }^{32}$ Washington Visit of Dr. Jagan and Mr. Beharry, British Guiana Cabinet Ministers. 2 August 1959, RG 59, Records of the Department of State, National Archives II, College Park, MD.
} 
the Office Director Level; nonetheless, the fact remains that for a fleeting moment in 1959, Cheddi Jagan began to make inroads toward reconciliation with the United States. ${ }^{33}$ However, attempts to appease the United States were half-hearted at best and even as Cheddi Jagan was charming to his hosts in Washington, he and Janet were undermining their cause with political activities elsewhere.

\section{The Increasingly Aggressive PPP Policy After the Cuban Revolution}

The Jagans continued to foster ties with Eastern bloc countries, which aroused the suspicion of concerned American officials between 1959 and 1960. Economic associations with Hungary and East Germany in 1959 were interpreted by Hugh Cumming as an effort to obscure aid coming from Communist nations and in April 1960 Jagan spoke openly of a potential trade agreement with Cuba. The fact that Jagan had just visited the revolutionary nation was not lost on Cumming. ${ }^{34}$ Cheddi Jagan returned to British Guiana in May 1960 after stopping in Trinidad to give a speech in which he spoke openly and strongly of supporting the Cuban Revolution and making the Cuban cause the cause of the rest of the Caribbean. He went so far as to suggest that the Guianese should take up arms to defend the Cubans against an attempted invasion by “imperialists”. ${ }^{35}$ United States Consul Everett Melby wrote to the Department of State in July summarizing the "communist situation in British Guiana”. The new American Consul had numerous and varied concerns including PPP rhetoric printed in the party's periodical Thunder;

\footnotetext{
${ }^{33}$ William Dale to Mr. White, 30 July 1959, RG 59, Records of the Department of State, National Archives II, College Park, MD.

${ }^{34}$ Hugh Cumming, to EUR, Central Decimal Files Box 1667, RG 59, Records of the Department of State, National Archives II, College Park, MD.

${ }^{35}$ Woods to Department of State, 11 May 1960, 741d.00/5-1060, Central Decimal Files Box 1667, RG 59, Records of the Department of State, National Archives II, College Park, MD.
} 
the importation of communist literature; communist contacts; Soviet Bloc trade, aid, and scholarships; and ties with Cuba. ${ }^{36}$

It is important to recognize that the PPP’s foreign policy became notably more aggressive in 1959. Apparent policy changes, including attempts at moderating domestic reform and reconciling with the United States, were reversed two years after the Colonial Office reintroduced internal self-government to British Guiana. It is possible that American indifference toward Jagan’s requests for aid influenced the Guianese leader to seek assistance elsewhere; however, further explanation is required to illustrate why Jagan turned to the communist world at that specific time. The success of the Cuban Revolution in early 1959 and its strong opposition to the United States appears to have been the catalyst for a reinvigoration of Jagan’s belief in Marxism. Jagan immediately moved to create economic ties with Cuba and voiced strong support for Fidel Castro in the ensuing five years. His positive response to events in Cuba, especially after Castro defined the Revolution as socialist, is consistent with his purported Marxist ideology. In an April 1960 speech in Trinidad, Jagan declared that Castro was "beloved by everyone” and suggested that British Guiana should come to the aid of Cuba if the United States intervened on the island. He continued to interpret the Cuban experience as proof that British Guiana could also effectively pursue independence without collaborating with the United States and sought solidarity with the Cubans. ${ }^{37}$ Thus, Jagan's altering of the PPP foreign policy toward greater association with the Eastern Bloc was a combination of a failure to obtain American aid and a reaction to the Cuban Revolution. The success of the Cuban Revolution

\footnotetext{
${ }^{36}$ Melby to Department of State, 6 July 1960, 741d.13/7-660, Central Decimal Files Box 1668, RG 59, Records of the Department of State, National Archives II, College Park, MD.

${ }^{37}$ Woods to Department of State, 11 May 1960, 741d.00/5-1060, Central Decimal Files Box 1667, RG 59, Records of the Department of State, National Archives II, College Park, MD.
} 
proved to Jagan that an independent course was possible with support from the Soviet Union and Cuba to counter American dominance.

Melby's opinion of Jagan deteriorated further on October 7, 1960 when newspapers in the colony reported on a meeting between Jagan and East Indian businessmen quoting Jagan as having told the businessmen that he would pursue ties with Cuba and the Soviet Union after independence and that he would not assure free elections after independence. Jagan's response to these accusations was simply to state that no newspapermen were present at the meeting. ${ }^{38}$ Thus, while questioning the legitimacy of the article, Jagan did not refute the claims of the article itself. His ambiguous response was typical and increasingly his indirect public statements were destructive to his image. Further damaging to the PPP's position was the establishment of educational relations between British Guiana and Eastern Bloc nations. In April 1960 Brindley Benn, a close associate of the Jagans and leading member of the PPP visited Berlin and on October 14, 1960, Cheddi Jagan announced at a press conference that the results of Benn's visit would soon be made public. He proudly proclaimed that six scholarships were to be awarded to Guianese students to be educated in East Germany. ${ }^{39}$

The relationship between the Jagans and Cuba was further emphasized as the State Department prepared for talks with British officials in 1961. In a position paper prepared by United States officials, the State Department directly referenced the Cuban loan offer as evidence that the Jagans were receiving financial support from Communist bloc countries. The report also

\footnotetext{
${ }^{38}$ Melby to Department of State, 7 October 1960, 741d.00/10-760, Central Decimal Files Box 1667, RG 59, Records of the Department of State, National Archives II, College Park, MD.

${ }^{39}$ Melby to Department of State 19 October, 1960, 741d.00/10-1960, Central Decimal Files Box 1667, RG 59, Records of the Department of State, National Archives II, College Park, MD.
} 
characterizes the Jagans politics as persistently flirting with the Sino-Soviet bloc. ${ }^{40}$ The flirtation cited included the maintenance of mail contact with communists in the West, frequent travel to communist groups in Western countries, relationships with people connected to Soviet embassies, and visits to communist nations. Also disconcerting to the State Department was the plethora of communist literature in the PPP library in British Guiana and the active promotion of Communist bloc nations in the party's weekly newspaper Thunder. This pattern of flirtation with communist groups was concerning enough to American officials, but there was more. Jagan's Achilles heel was his penchant for vocally supporting the international communist cause. ${ }^{41}$ The State Department was also aware of the fact that the PPP had received financial aid and organizational support for the upcoming Guianese elections from Chinese and Hungarian sources. ${ }^{42}$

The extent to which Cheddi Jagan misunderstood the effect of global events on his position is evidenced in a statement made in July 1961. With elections in the colony a month away, Jagan attempted to explain his position toward foreign relations. He claimed that he would continue a friendship with the United States under the condition that there were no strings attached and the Americans accepted his principles of economic planning. ${ }^{43}$ While this statement was not as incendiary to United States officials as his praise of the Cuban Revolution or his attempts to develop ties to Eastern Bloc nations, it belies an elemental flaw in Jagan’s political philosophy. The most important figure in Guianese politics overestimated his political leverage

\footnotetext{
${ }^{40}$ Position Paper prepared for U.S. Talks with the British, February 1961, U.S.-U.K. Talks-Feb-Mar 61, 5.18, Box 1, RG 59, Records of the Department of State, National Archives II, College Park, MD.

${ }^{41}$ U.S. Talks with the British: Position Paper: February 1961, US-UK Talks Feb-Mar 61, Central Decimal Files Box 1, RG 59, Records of the Department of State, National Archives II, College Park, MD.

${ }^{42}$ Memorandum of Conversation, Mr. H.M.E. Cholmondeley, 11 January 1961, 741d.00/1-1161, Central Decimal Files Box 1667, RG 59, Records of the Department of State, National Archives II, College Park, MD.

${ }^{43}$ Melby to Department of State, 3 July 1961, 741d.00/7-361, Central Decimal Files Box 1667, RG 59, Records of the Department of State, National Archives II, College Park, MD.
} 
and ability to chart a non-aligned course of action, especially because of British Guiana’s geographic proximity to the United States. The inability of the United States to control events in Cuba altered the American foreign policy and Jagan misinterpreted the consequences for his soon to be independent nation. The Cuban association with the Soviet Union solidified American opposition to further hemispheric social revolutions and minimized the latitude with which local politicians could conduct independent foreign policies, making the pursuit of a non-aligned policy virtually impossible. The American decision to organize anti-Castro Cubans to invade at the Bay of Pigs showed how adamantly the United States would try to squelch out any revolution in the hemisphere that might become communist. Jagan may have hoped to pursue a non-aligned foreign policy using his clientage as leverage to court the superpowers. However, American policymakers were adamant that regional leaders take sides in the Cold War, especially after the Cuban Revolution.

Furthermore, Jagan never fully understood the importance Great Britain placed on the Anglo-American relationship. If Jagan hoped that Guiana’s status as a British colony would give him latitude unavailable to independent hemispheric nations, he was incorrect. Relations with the United States superseded the British desire to permit their colonial subjects truly autonomous self-rule. In July 1961 Jagan simply did not comprehend that self-government for a British colony in the Caribbean would be predicated on ties to the United States. Ultimately, Jagan never seemed to understand that he had to take sides in the Cold War; and the consequences of taking sides with the Eastern Bloc would cause anger in the United States and lead them to undermine his regime. This fundamental flaw in Jagan's political view was crucial to decisions made over the subsequent two years by Britain and the United States, culminating in the Anglo-American meeting at Birch Grove, England in June 1963. There, key British and American officials 
decided to remove Jagan as head of the Guianese government and establish an independent Guyana under a coalition government made up of Burnham’s PNC and Peter D’Aguiar’s United Force (UF). ${ }^{44}$

\section{The Opportunity and Failure of PPP Policy from August 1961 to June 1962}

The Kennedy Administration reassessed its policy toward British Guiana after failing to thwart the PPP victory in August 1961. In early September Kennedy proposed a policy described as an "across-the-board, whole-hearted attempt" to work with Jagan. ${ }^{45}$ The complete nature of Kennedy Administration policy toward British Guiana is somewhat unclear due to the fact that a substantial number of high level documents on the matter remain classified. However, the PPP's electoral victory gave Jagan a legitimate opportunity to win the third constituency, the United States, and secure his position as head of an independent Guyana. In September 1961 the dominant position in the new government was still in the hands of the PPP, even if the American courtship of Jagan was half-hearted.

It is critical to note that President John F. Kennedy proposed a wholehearted diplomatic attempt to work with Cheddi Jagan in August 1961, at the behest of Great Britain, after the PPP won another colonial election. ${ }^{46}$ While the Kennedy Administration did not eliminate active CIA operations against communist elements in the PPP, it appears the attempt to remove Jagan temporarily became a contingency plan. Thus, Jagan was given a small window of opportunity to prove to key American policymakers that he was a capable leader who was willing to work within the constraints of the Cold War western hemispheric conditions. Between August 1961

\footnotetext{
${ }^{44}$ Memorandum of Conversation, Kennedy, Rusk, Bruce, Tyler, Macmillan, Home, Omsby-Gore, Sandys, et al. 30 June 1963, FRUS 1961-1963, 12: 295.

${ }^{45}$ Schlesinger to Kennedy, 12 January 1962, FRUS 1961-1963, 12:261.

${ }^{46}$ Schlesinger to Kennedy, 12 January 1962, FRUS 1961-1963, 12:261.
} 
and June 1963, Jagan’s decisions were increasingly damaging to his political image. At a meeting in Birch Grove, London, in June 1963 United States and British officials finally determined to eliminate Jagan as head of the Guianese government. ${ }^{47}$ Poorly disguised covert intervention displaced the PPP as the leading party in British Guiana and paved the road to independence under a coalition government headed by Forbes Burnham. Ultimately, it was the PPP's actions, coupled with the adroit diplomacy of Burnham and the lack of a viable third political figure, which solidified the American position and created the conditions under which intervention would be successful.

A crucial caveat to the explanation set forth in this thesis is that much of the supporting information is subject to refinement after further declassification of records from the United States government. There is some reason to suspect that the Kennedy administration's temporary policy of cooperating with Jagan was a stall tactic meant to appease British officials who were intent on granting independence to their colony at the earliest opportunity. Dean Rusk, the United States Secretary of State, sent a strongly worded message to Lord Alec Home of the Foreign Office in February 1962, mere days after the riots in Georgetown concluding that the Kennedy Administration had: "tr[ied] your policy” of working with Jagan and that “...I have reached the conclusion that it is not possible for us to put up with an independent British Guiana under Jagan. ${ }^{\text {48 }}$ Rusk’s comments could be interpreted as a way of seeing the riots as an excuse to abandon a policy never truly embraced by the Kennedy Administration. However, Rusk seems to have held an extreme view within the Kennedy Administration, and the evidence suggests that most American officials embraced the opportunity to work with Jagan, if reluctantly and only for a time.

\footnotetext{
${ }^{47}$ Schlesinger to Kennedy, 12 January 1962, FRUS 1961-1963, 12:261.

${ }^{48}$ Rusk to Home, 19 February 1962, FRUS, 1961-1963, 12: 544-45.
} 
There is more evidence that Kennedy’s stated policy change and decision to work with Jagan was really a stall tactic to placate British officials eager to grant independence to the colony. Correspondence between President Kennedy and Fowler Hamilton, Administrator for the Agency of International Development is interesting in light of other circumstantial evidence. Arthur Schlesinger, Special Assistant to the President, indicated on January 12 that delays in promised aid to British Guiana were threatening to undermine the president's proposed policy of “... an across-the-board, whole-hearted effort to work with Jagan.” Schlesinger feared that Jagan would conclude that the United States had determined not to work with him if aid was not soon forthcoming. ${ }^{49}$ Kennedy responded the same day with a memorandum for Hamilton demanding immediate steps to be taken reassuring Jagan and sending an economic mission to the colony. Kennedy set a deadline for this action of February $15 .{ }^{50}$ Riots erupted in Georgetown on February 12. This exchange could be interpreted in two ways. It is possible that Kennedy sincerely intended to work with Jagan and the riots were the result of the most unfortunate timing for Jagan. It is also possible, and there is some evidence to suggest, that the CIA was already working to undermine Jagan, and that Kennedy's deadline was strategically chosen to fall after the riots had begun.

The most plausible explanation is that Kennedy attempted to establish a relationship with Jagan, while instructing the CIA to continue operations in British Guiana in order to subvert the PPP government if diplomacy failed. It is also important to note that the Kennedy Administration was not unified in its opposition to Jagan until late June, 1962. For about a year, most of his advisors adopted a view somewhere between the extremes of Rusk, who adamantly opposed Jagan, and Schlesinger, who sought a diplomatic resolution to ideological disagreements with the

\footnotetext{
${ }^{49}$ Schlesinger to Kennedy, 12 January 1962, FRUS 1961-1963, 12:261.

${ }^{50}$ Kennedy to Hamilton, 12 January 1962, FRUS 1961-1963, 12: 262.
} 
PPP leader. Kennedy seems to have drifted toward Rusk after meeting with Jagan in October, 1961 and the rest of the administration followed over the next eight months.

There is some suggestion in the historiography that suggests Kennedy's stated attempt to work with Jagan was insincere, as the above examples illustrate; however, such an assumption is overly deterministic. ${ }^{51}$ Regardless of the genuineness of the Kennedy Administration's attempt to work with Jagan there are two key conclusions to be drawn which are essential to the premise that Jagan himself played a crucial role in losing his position in British Guiana. First, at least some key members of the Kennedy Administration were under the impression that working with Jagan was, in fact, genuine policy. It is possible that Schlesinger was simply in the dark about Kennedy’s true intentions; however, that would suggest a disjointed foreign policy in Washington at the highest levels. Secondly, the British response to Rusk's letter was a fiercely worded rebuttal to the Secretary’s conclusions and their implications. Foreign Secretary Alec Home strongly criticized Rusk’s suggestion that the British could undermine Jagan while upholding the vestiges of a democratic government in the colony. The exchange was intense and it is clear that the British were offended and, more significantly, opposed to Rusk’s suggestion that intervention was possible in British Guiana. ${ }^{52}$ British administrators were squarely behind Jagan in early 1962 and despite having some suspicion of Jagan, they felt he was the most adequate leader in the colony. Thus, despite subversive efforts by the United States, strong opposition from some upper level members of the Kennedy Administration, and a series of

\footnotetext{
${ }^{51}$ Stephen Rabe suggests that Kennedy used Jagan's appearance on Meet the Press in October 1961 as an excuse to pursue the policy of subversion which he intended to advance regardless. Rabe argues that Kennedy determined against working with Jagan prior to his meeting with the Guianese leader October 25. Despite Kennedy's personal feelings, there is evidence to suggest that his administration's policy was sincere, with the exception of Secretary of State Dean Rusk. More importantly, it is critical to acknowledge that the course of Guianese history was not determined on the personal feelings of the President of the United States alone. See: Rabe, U. S. Intervention in British Guiana, 87-88.

${ }^{52}$ Home to Rusk, 26 February 1962, FRUS 1961-1963, 12:266.
} 
political missteps following his electoral victory in August 1961, Jagan was far from defeated politically in early 1962.

Finally, it is important to qualify the impact that United States-inspired subversive attempts may have had in British Guiana. Much of the high level State Department correspondence which could clarify the exact nature of the United States role in subverting the PPP remains classified. Former CIA operative Philip Agee suggests that American backed covert operations began at least in 1959 and the work of scholars such as Stephen Rabe, Thomas Spinner, and Gordon Oliver Daniels has focused heavily on the role of American intervention as the determinant factor in the decolonization of British Guiana. ${ }^{53}$ However, this chapter suggests that even if there was a sustained covert attempt to dislodge Jagan, the likelihood of success would have been far from certain and while American inspired subversive attempts played a crucial role in effecting the trajectory of Guianese decolonization, they alone do not explain why the United States chose to undermine Jagan in the first place. The goals of covert interventions were achieved in instances such as Guatemala and Iran; however, they often failed disastrously, the clearest example of such failure being the Bay of Pigs invasion in Cuba. Schlesinger gave the probability of success for operations in British Guiana as less than fifty percent even after the Kennedy Administration shifted internal discussion from strategy, to tactics and determined to pursue solely a course of subverting Jagan. ${ }^{54}$ This chapter will suggest that after the PPP's electoral victory in August 1961 Jagan retained the support of Great Britain and the most critical capitalist investors in the colony. Additionally, it suggests that Jagan had an opportunity to

\footnotetext{
${ }^{53}$ Agee, Inside the Company, 416; Rabe, U.S. Intervention in British Guiana; Spinner, A Political and Social History of Guyana; Gordon Oliver Daniels, “A Great Injustice to Cheddi Jagan: The Kennedy Administration and British Guiana, 1961-63” (Ph.D. Diss., University of Mississippi, 2000).

${ }^{54}$ Schlesinger to Dungan, 19 July 1962, FRUS 1961-1963, 12: 282; Schlesinger to Kennedy, 5 September 1962, FRUS 1961-1963, 12: 288.
} 
establish an effective relationship with the Kennedy Administration until mid-1962. Therefore, while the exact beginning of CIA operations in British Guiana is uncertain, their existence alone did not guarantee the demise of the PPP. The PPP position became untenable only after Jagan failed at establishing an effective relationship with the Kennedy Administration and finally lost the support of British colonial officials. Ultimately, the Jagans' attempts to develop closer relations between British Guiana and the communist world was the primary factor which influenced Anglo-American policymaking and combined with external Cold War events, specifically in Cuba, to create an untenable situation for the PPP in British Guiana.

Kennedy invited Cheddi Jagan to Washington D. C. in October 1961 as an indication that the United States sincerely hoped to work with the Guianese politician, and more importantly as a way to determine Jagan's true ideological position. Jagan’s trip to the United States would prove to be the best opportunity he had to win the support of Washington, as well as an American public increasingly interested in international events in the Caribbean. The State Department "saw no real alternative to British policy" in early October and envisioned working with Jagan, if he could have a successful trip to the United States, according to Schlesinger. ${ }^{55}$ Jagan's visit would revolve around two key issues and his inability to comprehend the importance of the second issue proved to be a disastrous error. Jagan's primary goal in visiting Washington was to obtain economic aid crucial for the development of British Guiana. The Americans intended on determining once and for all Jagan's political ideology and intentions for an independent Guyana. Melby summarized the American view clearly in a telegram to Secretary of State Dean Rusk. He stressed: "Ideological issues should be met fully at outset at high level...We should tell him frankly our concern about Communist involvement and tell him

\footnotetext{
${ }^{55}$ Arthur Schlesinger, A Thousand Days: John F. Kennedy in the White House (Boston: Houghton Mifflin Company, 1965), 775.
} 
we expect equally frank statement from him on his position."56 Melby also noted that Jagan’s visit would prove to be: "an unparalleled opportunity to sell himself and his country to the U.S.”, while providing the ominous warning that: "U.S. newsmen are hard-headed pros who will needle him to see how he stands up under questioning.,57

The Prime Minister's visit began with an introduction to the American public on the weekly news program Meet the Press. Jagan's performance was a public relations debacle that tainted his trip to the United States and signaled the beginning of a final erosion of the working relationship Kennedy had hoped to establish. He responded to his interviewers with inept and ambiguous answers, dodging simple ideological questions posed to him, rather than providing frank statements to clarify his ideological position as American officials had hoped. ${ }^{58}$ When he did attempt to engage in ideological conversation, Jagan resorted to making statements that sounded like pure Leninist ideology. ${ }^{59}$ Kennedy's response was predictable in light of the circumstances. According to Schlesinger, the President responded to the interview by: "call[ing] for a re-examination of all aspects of the problem.” Jagan had placed himself in a difficult position before he gathered himself to meet the President the following day.

Kennedy and Jagan met on October 25, and the first order of business for the American President was to determine Jagan’s political ideology. Jagan evaded questions of doctrine, claiming that he was too unfamiliar with theory to distinguish between the various forms of socialism, which appeared to administration officials present to include communism. The

\footnotetext{
${ }^{56}$ Melby to Rusk, 13 October 1961 , 741d.00/10-1361, Central Decimal Files Box 1667, RG 59, Records of the Department of State, National Archives II, College Park, MD. Emphasis in original.

${ }^{57}$ Melby to Rusk, 14 October 1961, 741d.00, Central Decimal Files Box 1667, RG 59, Records of the Department of State, National Archives II, College Park, MD.

${ }^{58}$ Memorandum of conversation, Burdett, Melby, Gagrai, 28 March 1962, 741d.00/3-2862, Central Decimal Files Box 1668, RG 59, Records of the Department of State, National Archives II, College Park, MD.

${ }^{59}$ Gordon Oliver Daniels, “A Great Injustice to Cheddi Jagan: The Kennedy Administration and British Guiana, 1961-63” (Ph.D. Diss., University of Mississippi, 2000), 124.
} 
Guianese leader also claimed that he was uncommitted in the Cold War and he did not wish to become engaged in the conflict. ${ }^{60}$ Kennedy was discontented with Jagan's evasiveness and the fact that he also requested a massive aid package, which Schlesinger described as: "all out of proportion to the size of his country.” Nonetheless, Kennedy was aware of the British contention that Jagan remained the only viable option for leadership in a soon to be independent Guyana. ${ }^{61}$ Ultimately, the first and most outstanding failure in Jagan's attempt to establish himself as a legitimate head of state in the immediate years prior to independence was the direct result of his inadequate statesmanship, not operations conducted against him by a foreign power. American foreign policy in the Caribbean after the Cuban Revolution demanded that regional leaders rhetorically support the United States. Jagan's refusal to commit to supporting the United States convinced American officials that he was actively working against them.

Before the Kennedy administration had time to digest Jagan's visit, the Guianese leader and his party embarked on a relentless series of political maneuvers which added to the suspicion of United States officials. After returning to Georgetown the first week of November Jagan was quoted in the Trinidad Guardian suggesting that he would soon seek financial aid from the Soviet Union. ${ }^{62}$ Later that month, Melby forwarded information to the Department of State elaborating on the travels of six important PPP members, all of whom traveled to Cuba, Moscow, or Eastern Bloc nations. ${ }^{63}$ In closing an independence motion debate for the colony, Jagan referred to capitalism in the United States as a dying system, which he elaborated on in an

\footnotetext{
${ }^{60}$ Memorandum of Conversation, Kennedy, Schlesinger, Ball, Jagan, et al, 25 October 1961, 841d.00/10-2561, Central Decimal Files Box 2478, RG 59, Records of the Department of State, National Archives II, College Park, MD.

${ }^{61}$ Schlesinger, A Thousand Days, 775-778.

${ }^{62}$ Foreign Service Dispatch from Deputy Chief of Mission: U.S. Mission Port of Spain to Department of State, 8 November 1961, 741d.00/11-861Central Decimal Files Box 1667, RG 59, Records of the Department of State, National Archives II, College Park, MD.

${ }^{63}$ Melby to Department of State, 25 November, 1961, 741d.00/11-2561, Central Decimal Files Box 1667, RG 59, Records of the Department of State, National Archives II, College Park, MD.
} 
attempt to prove the evils of such an economic structure and later was quoted refusing to assure free elections after independence. ${ }^{64}$ Beginning in December, Jagan actively sought a solution to the racial discrepancy in the colony’s armed civil services. His pursuit of arms and training from various sources was a constant cause of suspicion from United States officials.

Resolving the drastic racial imbalances in the police force was a legitimate concern. Increasing polarization of politics on ethnic grounds between 1955 and late 1961 was beginning to manifest itself in violent ways. A racially diversified police force was essential for the colony to maintain order in the post-independence period. However, Jagan’s decision to pursue training from Israel and arms from a number of Eastern Bloc sources, rather than the United States, represents another failure of Jagan to properly contextualize his political reality. The reaction of Secretary of State Dean Rusk in response to an article in the Jerusalem Post is useful in understanding the key problem with Jagan’s policy. Rusk sent a telegram to American Embassies in London and Tel Aviv and the Consulate in Georgetown seeking further information about Jagan's pursuit of Israeli military assistance in conjunction with rumors of a PPP attempt to form youth camps in British Guiana for physical training and political indoctrination. ${ }^{65}$ Melby confirmed that the PPP had intentions of creating a supplemental police force loyal to the party. ${ }^{66}$ Jagan had failed to realize that actively seeking arms and military training, and keeping the United States in the dark about it, would only result in more suspicion from Washington. His

\footnotetext{
${ }^{64}$ Melby to Department of State, 15 December, 1961, 741.00/12-1561, Central Decimal Files Box 1667, RG 59, Records of the Department of State, National Archives II, College Park, MD; Rusk to Bruce, 4 December 1961, 741d.13/12-461, Central Decimal Files Box 1668, RG 59, Records of the Department of State, National Archives II, College Park, MD.

${ }^{65}$ Rusk to Amembassy London, Tel Aviv, Amconsul Georgetown, 19 December, 1961, 741d.00, Central Decimal Files Box 1667, RG 59, Records of the Department of State, National Archives II, College Park, MD.

${ }^{66}$ Melby to Rusk, 21 December 1961, 741d.00/12-2161, Central Decimal Files Box 1667, RG 59, Records of the Department of State, National Archives II, College Park, MD.
} 
actions reinforced the fears held by American policymakers that he was secretly attempting to establish a communist beachhead on mainland South America.

The foreign policy of the PPP continued to antagonize the United States during the first month and a half of 1962, even as the domestic situation in British Guiana became increasingly volatile. The American Embassy in Warsaw informed the Department of State on January 18 that Janet Jagan visited Poland and was interviewed by Slowo Powzechne en route to Moscow. ${ }^{67}$ An article in the PPP newspaper Thunder earlier in the month attributed inflammatory comments about capitalism to the party's Parliamentary Secretary, Jack Kelshall, who claimed that the PPP would "ultimately destroy” big business. Melby forwarded this information to the Department of State, adding that the Secretary was a close associate of Cheddi Jagan and his comments should be assumed to be party dogma. ${ }^{68}$

By mid-January 1962 five months had passed since Jagan won re-election and the Kennedy Administration had agreed to attempt to work with the Prime Minister. Rather than engaging in insightful statesmanship during that period, Jagan's actions in fact reinforced the American perception that he was a communist conspirator who was seeking to establish a second Cuba on the South American mainland. Posterity suggests that American fears were considerably overblown and perception obscured by what is frequently referred to as Cold War lenses. However, in January 1962, Jagan was proving that he lacked the ability to conduct a realistic foreign policy and effectively promote his party's cause. Despite Jagan’s imprudent dealings, he was still the colony's leading political figure and his only legitimate rival, Burnham, was

\footnotetext{
${ }^{67}$ Amembassy Warsaw to Department of State, 18 January 1962, 741d.00, Central Decimal Files Box 1668, RG 59, Records of the Department of State, National Archives II, College Park, MD.

${ }^{68}$ Melby to Department of State, 10 January 1962, 741d.00, Central Decimal Files Box 1667, RG 59, Records of the Department of State, National Archives II, College Park, MD.
} 
unappealing to both the United States and Great Britain. Therefore, Jagan retained a clear advantage over his opposition when the Georgetown riots began on February 12.

Demonstrators took to the streets of Georgetown on February 12, ostensibly objecting to Jagan's proposed budget and a compulsory savings scheme. Within four days the city was ablaze as racial antagonisms exploded and protests turned violent. Burnham and D'Aguiar used the budget and increasing unrest as an attempt to oust the Jagan government from power. ${ }^{69}$ It is almost certain that Burnham was receiving financial assistance from the United States, or at least American labor unions, to prolong the strike. ${ }^{70}$ Unrest was finally quelled by the arrival of British troops in the city, not by any action of the PPP-led government. The implications of American involvement in the disturbance are somewhat misleading. The most likely explanation is that the Kennedy Administration's contingency plan of subverting the PPP government took on a new level of urgency with the prospect of independence for the colony in the very near future. Violent unrest could be used as a pretext for delaying self-government until the United States could determine what to do about Jagan. However, it would be premature to allege that differences between Jagan and the United States had become entirely irreconcilable or that the Kennedy Administration had established a definitive position of opposition to Jagan.

Despite Rusk's conclusion on February 19 that the United States could not accept a Jagan-led government, Kennedy stated plainly that no decision had been made on policy toward British Guiana almost a month later. ${ }^{71}$ Alec Home’s biting response to Rusk and Ian MacLeod's strong assertion that Jagan was not a communist and: “infinitely preferable to Burnham” makes

\footnotetext{
${ }^{69}$ Rabe, U.S. Intervention in British Guiana, 89-91; Spinner, Political and Social History of Guyana, 95-98.

${ }^{70}$ Melby to Department of State, 20 March 1962, 841d.06/3-2062, Central Decimal Files, RG 59, Records of the Department of State, National Archives II, College Park, MD.

${ }^{71}$ Rusk to Home, 19 February 1962, FRUS, 1961-1963, 12: 544-45; Kennedy to Rusk, 8 March 1962, 741d.00/3862, Central Decimal Files Box 1668, RG 59, Records of the Department of State, National Archives II, College Park, MD.
} 
clear that British officials still considered Jagan the legitimate leader of the colony and had no intentions of subverting his government. ${ }^{72}$ Retrospectively it is apparent that the United States was in the process of assuming the lead role in British Guiana; however, in early 1962 British Guiana remained under the authority of Great Britain. The British Colonial Office was responsible for making the final determination of who would lead the colony upon independence, and in March 1962, the British did not seriously entertain the thought of eliminating Jagan in lieu of Burnham.

Finally, Jagan retained the support of the primary capital investors in the colony, Bookers Brothers and ALCON, who stated plainly that he was preferable to any alternative leader. ${ }^{73}$ Their support was more of an indictment against Burnham than confidence in Jagan; nonetheless, even after the riots, Jagan remained the most likely prospect to lead the colony to independence. His hold on the government was slipping and the opportunity to achieve the necessary support of the United States was eroding at a quickening pace; however, he held the support of virtually every other powerful group interested in the future of the colony. Rusk's opinion can be taken as an indicator of a strengthening opposition at the highest levels of the United States government; however, it was not an indication that Jagan's government had become unsustainable. It was not even an indication of a unified policy opposing Jagan within the United States government.

From a political standpoint, the most damaging aspect of the riots for the PPP was the realization that without British assistance, Jagan was incapable of maintaining order in the colony. Colonial officials were increasingly fearful that British Guiana would degenerate into

\footnotetext{
72 Rusk to Home, 19 February 1962, FRUS, 1961-1963, 12: 544-45; Kennedy to Rusk, 8 March 1962, 741d.00/3862, Central Decimal Files Box 1668, RG 59, Records of the Department of State, National Archives II, College Park, MD; Schlesinger to Bruce, 27 February 1962, FRUS 1961-1963, 12: 267.

${ }^{73}$ Memorandum of Conversation, Washington 17 March 1962, FRUS 1961-1963, 12: 273.
} 
open racial warfare and even civil war after Her Majesty’s troops were withdrawn. ${ }^{74}$ The international community, specifically the United Nations (UN), was increasingly concerned with the humanitarian effects of global decolonization in the wake of disastrous European withdrawals from Africa. While many British officials had sincere concern for their former colony, international pressure to depart in an orderly fashion was the greatest factor impacting British withdrawal strategies. Great Britain did not want to lose standing in the international community by granting premature independence to the colony if the consequence was domestic strife. ${ }^{75}$ Burnham’s best opportunity to gain British support was by proving that a Jagan-led government would lead to instability and internal discord. The riots placed that idea in the minds of British officials for the first time.

As damaging as the riots were to Jagan, the response of his party had a worse effect on his standing, both in the colony and internationally. An article in Thunder attributed the riot to a plot by "fascists" in Washington and claimed that it was a: “dismal failure on the part of the CIA and its stooges." ${ }^{76}$ The consequence of aggressively condemning the United States was further antagonizing an already hostile administration, regardless of the accuracy of the claim that elements in Washington were behind or involved in the violence. Jagan himself made no public reply to the challenge of his authority, confirming to many his impotence as a leader. The only statements from the PPP were made were passing remarks by Kelshall and Janet Jagan. ${ }^{77}$ Finally,

\footnotetext{
${ }^{74}$ The National Archives, Kew, Richmond, Surrey (hereafter TNA), Colonial Office (hereafter CO) 1031/4405, Records of the West Indian Department, Outward Telegram from the Foreign Relations Office, 1 November 1963.

${ }^{75}$ Ronald Hyam, Britain's Declining Empire: The Road to Decolonization, 1918-1968 (Cambridge: Cambridge University Press, 2006). Hyam provides a comprehensive analysis of several crucial factors leading to and impacting British decolonization. He concludes that the re-ordered international community after World War II was the most important factor in shaping the timing and manner of the process.

${ }^{76}$ Melby to Rusk, 24 February 1962, 741d.00/2-2362, Central Decimal Files Box 1668, RG 59, Records of the Department of State, National Archives II, College Park, MD.

${ }_{77}$ Melby to Rusk, 28 April 1962, 741d.00/4-2662, Central Decimal Files Box 1668, RG 59, Records of the Department of State, National Archives II, College Park, MD.
} 
the PPP increased its attempts to establish a police force loyal to the party as an alternative to the current Afro-Guianese dominated civil services. This maneuver appeared reasonable on the surface; however, Jagan's decision to act without consulting Great Britain or the United States, served only to arouse suspicion about his intentions. ${ }^{78}$

Conversely, Forbes Burnham was working diligently to gain the support of United States officials. Burnham requested arms from the United States base at Atkinson Airfield during the February crisis, allegedly to stop the violence. Melby was quick to criticize Burnham's actions as irresponsible and the PNC leader as more dangerous than ever; however, his negative response obscures one critical fact: Burnham had looked to the United States for assistance in the crisis. ${ }^{79}$ The considerable number of classified documents in United States government records leaves open the possibility that Burnham was acting under the advice of American agents, and he certainly was responsible in part for stimulating the violence in the first place. Regardless, the crucial conclusion to be drawn from the comparison is that Burnham had begun to actively seek allegiance with the United States while Jagan seemed politically lost and responded to the crisis by lambasting the Americans. From the perspective of the Kennedy Administration, the Cuban Revolution made Western Hemispheric unity more vital than ever by early 1962. Burnham took advantage of this political reality and vehemently sought to win approval in the United States on every level. He worked to appease diplomats while appealing to the African-American public by vocally supporting Martin Luther King, $\mathrm{Jr}^{80}$ Foreign policy dynamics would ultimately determine which Guianese leader would win the third constituency and lead the colony to

\footnotetext{
${ }^{78}$ Melby to Rusk, 21 December 1961, 741d.00/12-2161, Central Decimal Files Box 1668, RG 59, Records of the Department of State, National Archives II, College Park, MD; Rusk to American Embassy London, Tel Aviv, American Consul Georgetown, 19 December 1961, 741d.00/11-1561, Central Decimal Files Box 1668, RG 59, Records of the Department of State, National Archives II, College Park, MD.

${ }^{79}$ Melby to Rusk, 20 March, 1962, 841d.06/3-2062, Central Decimal Files Box 2478, RG 59, Records of the Department of State, National Archives II, College Park, MD.

${ }^{80}$ Rabe, U.S. Intervention in British Guiana, 155.
} 
independence and Burnham was beginning to prove that he had the advantage in diplomatic ability.

The spring of 1962 saw two important developments in Guianese politics which further exemplify the opposing courses being pursued by Jagan and Burnham. On April 28 the PPP held its annual party elections with the result being a radicalization of the organization. Balram Singh Rai, Minister of Home Affairs, either left or was expelled from the party allegedly because he opposed the strong communist direction the party was moving toward. ${ }^{81}$ While Melby kept the State Department informed of developments within the PPP, Burnham was working with AFLCIO president George Meaney and pushing for a visit to the United States. ${ }^{82}$ Despite misgivings from some officials in the State Department about how such a meeting would be interpreted by the British, Burnham arrived in the United States in early May and met with Schlesinger on May 3. Burnham achieved a rousing success where Jagan had failed miserably six months earlier. Burnham spoke at length about developing ties to the United States and explained that he advocated private enterprise in an independent Guyana, while inquiring about obtaining educational scholarships for Guianese students to travel to the United States. Burnham also claimed to have begun to resolve the Venezuela border crisis, which remained an internationalrelations concern for the inter-American community after British Guiana achieved independence. Finally, Burnham told Schlesinger that he knew from personal experience that the Jagans were international communists and that Janet Jagan had been in Cuba as recently as February. ${ }^{83}$ Schlesinger was so impressed by Burnham that he invited him for drinks the following

\footnotetext{
${ }^{81}$ Melby to Department of State, 28 April 1962, 741d.00/4-2862, Central Decimal Files Box 1668, RG 59, Records of the Department of State, National Archives II, College Park, MD.

${ }^{82}$ Rusk to Melby, 26 April 1962, 741d.00/4-2662, Central Decimal Files Box 1668, RG 59, Records of the Department of State, National Archives II, College Park, MD.

${ }^{83}$ Memorandum of Conversation, Burnham, Schlesinger, Moscoso, et al., 3 May 1962, 741d.00/5-362, Central Decimal Files Box 1668, RG 59, Records of the Department of State, National Archives II, College Park, MD.
} 
evening. ${ }^{84}$ Adding to Burnham's success was the fact that Jagan visited the UN in New York during the same month, and met with Soviet and Polish diplomats, while never approaching anyone from the United States. ${ }^{85}$

There is a stark contrast between Burnham's visit in May and Jagan's visit six months earlier and the difference is telling. Jagan's insistence on defending his ideological position and his inability to successfully engage important American officials was the catalyst for his lost opportunity with the United States. Burnham, in contrast, whose personal character was highly suspect to British and American officials alike, won over American diplomats during his visit. ${ }^{86}$ Burnham did not permit his socialist ideology to hamper his persistent courtship of the third constituency over the summer of 1962. Like Figueres in Costa Rica and Trujillo during the 1930s and 1940s, Burnham adapted his ideology to political realities while Jagan struggled through the Royal Commission hearings into the February riots. Most notably, Burnham understood the declining influence of Great Britain and the overwhelming significance of acknowledging the primacy of the United States in the Western Hemisphere. Slowly, Burnham’s political opportunism and Jagan’s struggle to keep to his ideals convinced the Kennedy Administration that Burnham was the necessary, if far from ideal, choice to lead British Guiana to independence.

The political climate in British Guiana increasingly favored Forbes Burnham into the summer of 1962 and by the end of June, Cheddi Jagan had finally destroyed his changes of

\footnotetext{
${ }^{84}$ W.R. Tyler to Alexis Johnson, 4 May 1962, 741d.00/5-462, Central Decimal Files Box 1668, RG 59, Records of the Department of State, National Archives II, College Park, MD; Ball to Melby and Burdett, 7 May 1962, 741d.00/5-7627, Central Decimal Files Box 1668, RG 59, Records of the Department of State, National Archives II, College Park, MD.

${ }^{85}$ Stevenson to Rusk, 24 May 1962, 741d.00/5-2462, Central Decimal Files Box 1668, RG 59, Records of the Department of State, National Archives II, College Park, MD.

${ }^{86}$ Memorandum of Conversation, Wendell Bobb, Don Clouse, Arthur Schlesinger, 15 December, 1961, 841d.06/121562, Central Decimal Files Box 2478, RG 59, Records of the Department of State, National Archives II, College Park, MD; Ball to Melby and Burdett, 7 May 1962, 741d.00/5-7627, Central Decimal Files Box 1668, RG 59, Records of the Department of State, National Archives II, College Park, MD.
} 
reconciliation with the United States. On June 4 Burnham repeated his request to the United States for educational scholarships for Guianese students, to counter his opponents attempt to send students behind the "Iron Curtain”. ${ }^{87}$ Meanwhile, PPP Acting Premier Brindley Benn was quoted on several occasions praising the impending success of communism and criticizing the United States. $^{88}$ Rai left the PPP for good on June 21, indicating to Melby that the PPP was moving in a more radical direction. ${ }^{89}$ Despite these developments, British Prime Minister Harold Macmillan told Kennedy that he hoped the United States would continue to try and work with Jagan if he remained the choice of the people. ${ }^{90}$ It is imperative to note that even in mid-1962 Jagan held the political high ground on every front except with his relationship to the United States. Jagan had spent nearly a decade as the head of, or primary figure in, Guianese politics and he had consistently engaged in political moves indicating a communist inclination. For nine months after Kennedy’s call for cooperation, Jagan pursued poorly conceived foreign diplomacy, yet he had not entirely isolated himself from the United States. Jagan’s Waterloo occurred during the Riot Commission Hearings in late June, and this time, his blunder was one from which he would not recover.

From June 22-28, 1962, Great Britain held a public inquiry into the disastrous riots of the previous February in Georgetown. Lionel Luckhoo, an East Indian lawyer, questioned Cheddi Jagan’s political ideology during the proceedings in a manner similar to Jagan’s interview on

\footnotetext{
${ }^{87}$ Memorandum of Conversation, Tyler, Burdett, et al., 4 June 1962, 741d.00/6-462, Central Decimal Files Box 1668, RG 59, Records of the Department of State, National Archives II, College Park, MD.

${ }^{88}$ Melby to Department of State, 24 May 1962, 741d.00/5-2462, Central Decimal Files Box 1668, RG 59, Records of the Department of State, National Archives II, College Park, MD; Melby to Department of State, 6 June 1962, 741d.00/6-662, Central Decimal Files Box 1668, RG 59, Records of the Department of State, National Archives II, College Park, MD.

${ }^{89}$ Wm. F. Schnitzler (AFL-CIO VP) to Vice President Johnson, 21 June 1962, 741d.00/6-2662, Central Decimal Files Box 1668, RG 59, Records of the Department of State, National Archives II, College Park, MD.

${ }^{90}$ Telegram from the Department of State to U.S. Embassy, London including text of a letter from Macmillan to Kennedy, Washington, 7 June 1962, FRUS 1961-1963, 12:276.
} 
Meet the Press the previous October. Jagan's ability to withstand difficult questioning had not improved. After several inconclusive responses to Luckhoo's interrogation, Jagan finally uttered the phrase which annihilated his chances of ever working with the United States: "I am a communist." ${ }^{91}$ To the Kennedy Administration, those words spoken by a man who was a political liability at best, and perhaps an international communist, combined with a long list of suspicious relationships with the Eastern Bloc, confirmed their worst fears. American reaction was immediate and conclusive. Connecticut senator Thomas Dodd reiterated Jagan's remarks on the floor of the senate the first week of July, including further statements made during the hearings where Jagan referred to Castro as "the greatest liberator of the twentieth century." United States senators received thousands of letters from American citizens objecting to the idea of sending aid to British Guiana so long as Jagan remained in charge of the colony. ${ }^{93}$ The same week Jagan’s personal secretary, Jack Kelshall, stated flatly that both he and Jagan were communists, which only served to further confirm to Melby that Jagan's assertion should be taken seriously. ${ }^{94}$ Jagan's statement was the culmination of a decade of ill-conceived diplomacy and ideological statements and the result was a final severance with the United States.

The Kennedy Administration never again entertained working with Jagan and that policy continued through the Johnson Administration until Jagan was effectively defeated through an engineered electoral scheme in which Burnham ascended to the primary position of authority in British Guiana, and in time, led the colony to independence. By mid-July 1962, United States

\footnotetext{
${ }^{91}$ Melby to Department of State, 29 June 1962, 741d.00/6-2962, Central Decimal Files Box 1668, RG 59, Records of the Department of State, National Archives II, College Park, MD.

${ }^{92}$ Thomas Dodd to Richard Goodwin, 9 July 1962, 741d.00/7-962, Central Decimal Files Box 1667, RG 59, Records of the Department of State, National Archives II, College Park, MD; Transcript of hearing from Daily Chronicle.

${ }_{93}$ Paper Prepared in the Department of State: Washington, 15 March 1962, FRUS 1961-1963, 12:272.

${ }^{94}$ Melby to Department of State, 8 July 1962, 741.00/7-862, Central Decimal Files Box 1668, RG 59, Records of the Department of State, National Archives II, College Park, MD.
} 
officials had ceased discussing strategy in British Guiana and began discussing tactics, committing themselves completely to a covert program to overthrow Jagan. The determination that Jagan would be subverted was final, what remained was convincing Great Britain to go along with the American plan. ${ }^{95}$

\section{The Loss of British Support and the Anglo-American Decision to Remove the PPP}

Jagan’s political strategy remained consistent throughout the subsequent year. He continued to pursue arms and training deals with Israel, provoking the ire of British officials who were displeased with Jagan's attempt to circumvent the colonial government in his effort to improve the police force. ${ }^{96}$ PPP members continued to negotiate closer ties to communist nations and travel between the colony and communist nations went on unabated. ${ }^{97}$ The Jagans still spoke affectionately of Castro and the communist world, even after the Cuban Missile Crisis. ${ }^{98}$ More importantly, Jagan continually put the British in an awkward position vis a vis the United States. Meanwhile, Burnham worked tirelessly to foster ties with the United States, traveling to New York to reassure American officials that he would remain anti-communist after Jagan was

\footnotetext{
${ }_{95}$ Bundy to Kennedy, 13 July 1962, FRUS 1961-1963, 12:281; Schlesinger to Kennedy, 5 September, 1962, FRUS 1961-1963, 12: 288.

${ }^{96}$ Bruce to Rusk, 9 August 1962, 741d.00/8-962, Central Decimal Files Box 1667, RG 59, Records of the Department of State, National Archives II, College Park, MD; Melby to Department of State, 25 November 1962, 641d.84a, Central Decimal Files Box 1334, RG 59, Records of the Department of State, National Archives II, College Park, MD; Amembassy London to Secretary of State, 9 August 1962, 641d.00, Central Decimal Files Box 1334, RG 59, Records of the Department of State, National Archives II, College Park, MD

${ }^{97}$ Melby to Department of State, 9 September 1962, 641d.93/9-962, Central Decimal Files Box 1334, RG 59, Records of the Department of State, National Archives II, College Park, MD, Hubbard in Cuba, etc

${ }^{98}$ Melby to Rusk, 20 January 1963, 741d.00, Central Decimal Files Box 1667, RG 59, Records of the Department of State, National Archives II, College Park, MD.
} 
defeated..$^{99}$ In December he pressed Melby for the third time to obtain scholarships for Guianese students to study in the United States. ${ }^{100}$

Despite the totality of the American aversion to Jagan, a number of British colonial officials, and members of Parliament, remained adamantly opposed to Burnham. The majority of British officials, specifically those in the Colonial Office, believed that the best scenario for an independent Guyana was a government under Cheddi Jagan. ${ }^{101}$ There continued to be contentious exchanges between the British Foreign Office and the State Department in Washington over the future of British Guiana throughout late 1962 and early 1963. Some members of the Colonial Office never agreed with the American decision to back Forbes Burnham. However, the overriding imperative for Great Britain in British Guiana was preparing the colony for independence. Since the early 1960s, the British had been eager to shed the weight of an economically draining relic of imperialism and sought to establish a stable, sustainable government in British Guiana. ${ }^{102}$ By 1963 Jagan's failure to maintain multi-racial support in the colony, in part because of inter-racial conflict fostered by the United States, had rendered the PPP incapable of sustaining social order. The primarily Afro-Guianese police force simply stopped accepting orders from the elected government, effectively leaving Jagan the head of a government which did not function. While it is important to acknowledge that elements of the United States government worked to achieve this end for several years, the British took care to note that: "Jagan and his party have constituted the government of the colony for the last six

\footnotetext{
${ }^{99}$ Melby to Rusk, 3 September 1962, 741./9362, Central Decimal Files Box 1668, RG 59, Records of the Department of State, National Archives II, College Park, MD.

${ }^{100}$ Melby to Rusk, 14 December 1962, 741d.00, Central Decimal Files Box 1667, RG 59, Records of the Department of State, National Archives II, College Park, MD.

${ }^{101}$ TNA, CO 1031/4405, Records of the West Indian Department, House of Commons Extract From Official Report of Queens Speech Debate-Constitution, 15 November 1963.

102 TNA, CO, 1031/4405, Records of the West Indian Department, British Policy Toward British Guiana, 1 November 1963.
} 
years [and thus] they and their policies must bear a share of the blame." ${ }^{, 103}$ Inequalities in the racial composition of the Guianese police force left Forbes Burnham the only Guianese leader capable of ending the social unrest and stabilizing Guianese society in a short amount of time. Thus, British and American imperatives in British Guiana began to run parallel and made the British decision to work with the United States possible.

After delaying independence for a year, British officials came to the realization that the schism between Jagan and the United States was irreparable, and that regardless, Jagan was incapable of establishing stability in the colony. British and American officials agreed that the PPP would move to establish a communist government based on the Cuban model after independence. American officials were confident that intervention was necessary to thwart the communist threat, while the British suggested that there was a possibility of internal opposition in British Guiana being strong enough to keep Jagan from succeeding. ${ }^{104}$ Despite misgivings about Burnham, the British acquiesced to American wishes. Britain’s desire to withdraw from the colony and the strength of the United States Cold War imperatives superseded British hesitation to support Burnham. Anglo-American talks were held at Birch Grove, England on June 30, 1963 and Kennedy, Rusk, and McGeorge Bundy traveled from the United States to meet with Macmillan, Home, and Colonial Secretary Duncan Sandys. The discussion shifted between British opposition to Burnham and American refusal to work with Jagan until Sandys finally concluded that a: “Burnham-D’Aguiar government will collapse by itself...unless...United States was prepared to shore it up, this would change the situation.”105

\footnotetext{
${ }^{103}$ TNA, CO 1031/4405, Records of the West Indian Department, Outward Telegram from the Foreign Relations Office, 1 November 1963.

104 TNA, CO 1031/4866, Records of the West Indian Department, Analysis prepared jointly by U.S. and British officials meeting in London, 25-27 June 1963.

${ }^{105}$ Memorandum of Conversation at Birch Grove, England, 30 June 1963, FRUS, 1961-1963, 12:295.
} 
The United States contingency caught the insinuation and Jagan’s fate was sealed. Despite Labour Party opposition, Sandys began working on implementing a plan of proportional representation for the next round of colonial elections, which led to a victory for the BurnhamD’Aguiar coalition and Jagan's defeat in the final elections before independence in British Guiana. ${ }^{106}$

The defeat of the PPP in British Guiana prior to independence was the culmination of several important factors. Cold War imperatives effected Anglo-American strategy in the Caribbean. Covert intervention by the United States destabilized the colony and challenged PPP authority in Georgetown. Great Britain's decision to pursue electoral change and a final election before independence resulted in Jagan's loss at the polls in December 1964 paving the way for Burnham to lead the colony to self-rule. However, the PPP's attempt to move British Guiana into the communist camp, and Forbes Burnham's timely courting of the United States, provided the most important basis for the policies pursued by the United States and Great Britain. The actions of these men ultimately framed the policy options available in Washington and determined the future of their country. Politics do not occur in a vacuum, a reality which is obvious in two ways for Guyana. Cheddi Jagan’s inability to conduct a foreign policy based on his political reality condemned him to ideological policymaking and political failure. Additionally, United States officials determined to implement a more forceful anti-communist policy after the Cuban Revolution and Castro's seizure of power in Havana. Their opposition to Jagan was not based on a McCarthy-esque witch hunt. Rather, it was predicated on Jagan's persistent Marxist ideology and the PPP’s foreign policy which was increasingly antagonistic toward the United States. It

\footnotetext{
${ }^{106}$ Visit of Foreign Secretary Gordon Walker: October 26-27, 1964: Talking Points Paper, Bureau of Inter-American Affairs Asst. Secretary \& U.S. Coordinator Alliance For Progress, Subject and Country Files, 1962-75, Box 1, British Guiana 1964, RG 59, General Records of the Department of State, National Archives II, College Park, MD.
} 
was the logical response to the maneuvers of Jagan himself in the context of a Cold War Caribbean. 


\section{Chapter 5: Conclusion}

This thesis examined the end of colonial rule in British Guiana as a microcosm to explore how changes in the global power structure were manifested in the collective dynamics of the Cold War and global decolonization during the mid-twentieth century. Decolonization in British Guiana was similar to that which was occurring simultaneously across the globe as European empires prepared their colonies for independence after the Second World War. Nationalist leaders maneuvered to pursue the most independent form of government available within the context of the post war world, always framed by the superpower struggle between the United States and the Soviet Union as well as the interests of colonial powers trying to end their domination of developing areas in the most advantageous manner possible. Guianese leaders were free to pursue self-government, but only within a specific framework acceptable to the United States, which sought to assert itself as the hemispheric leader by pressuring decolonizing Caribbean nations into alignment with the West, specifically after the Cuban Revolution and its subsequent alignment with the Soviet Union. British Guiana’s geographic proximity to the United States ensured that the American government would wield a strong influence on the decolonization process of the colony. Guianese politicians aimed to achieve independence as quickly as possible, but only under circumstances which would benefit them as individual leaders. Cheddi Jagan’s attempt to establish either a non-aligned or communist oriented foreign policy directly conflicted with the United States and led to American intervention in the colony. Conversely, Forbes Burnham pursued a foreign policy aligned with the United States. By courting American leadership, Burnham assured his position as the head of British Guiana after independence. At varying points in the decolonization process, the United States, Great Britain, and each individual Guianese leader were motivated to push for an increase or decrease in the 
pace of British withdrawal from the colony. Thus, the story of Guianese independence is the story of the competing interests of nationalist leaders, former colonizers, and a Cold War superpower.

This thesis is also a study of United States Cold War policy in the post-Cuban Revolution Caribbean. American policy in the hemisphere underwent significant changes in the early years after Fidel Castro's government took power in Havana. The complexity of these changes is evident in British Guiana. President John F. Kennedy took a harder line against communism as a result of the Cuban association with the Soviet Union; however, after the Bay of Pigs fiasco, Kennedy sought to pragmatically work with regional leaders who engaged in moderate domestic policies. ${ }^{1}$ Thus, the United States presented regional leaders with the latitude to engage in some programs of domestic reform if they could conduct an effective foreign policy with the United States. ${ }^{2}$ Comparing the foreign policies of the People's Progressive Party (PPP) and the People's National Congress (PNC) provides an excellent example of the American policy in the region.

The first chapter examined how the colonial history of British Guiana created a volatile society with distinct political, economic, and social characteristics which defined the manner in which the colony progressed toward independence. Colonial structures and immigration patterns created a culturally pluralistic society in British Guiana which nationalist leaders and foreign powers exploited with violent consequences during the independence period. ${ }^{3}$ British Guiana’s

\footnotetext{
${ }^{1}$ Arthur M. Schlesinger, Jr., A Thousand Days: John F. Kennedy in the White House (Boston: Houghton Mifflin Company, 1965), 776.

${ }^{2}$ Kyle Longley, The Sparrow and the Hawk: Costa Rica and the United States During the Rise of Jose Figueres (Tuscaloosa: The University of Alabama Press, 1997); Eric Paul Roorda, The Dictator Next Door: The Good Neighbor Policy and the Trujillo Regime in the Dominican Republic, 1930-1945 (Durham: Duke University Press, 1998).

${ }^{3}$ Leo A. Despres, Cultural Pluralism and Nationalist Politics in British Guiana (Chicago: Rand McNally and Company, 1967; Cheddi Jagan, The West On Trial: My Fight For Guyana's Freedom (New York: International Publishers, 1966); Stephen G. Rabe, U.S. Intervention in British Guiana(Chapel Hill: The University of North Carolina Press, 2005) ; Thomas Spinner, A Political and Social History of Guyana 1945-83 (Boulder: Westview
} 
political development was also the result of its colonial development and the nature of political organizations and ideology in the colony resulted in conflict with the United States. ${ }^{4}$ Thus, the decolonization process in British Guiana was the culmination of its colonial legacy of ethnic segregation and union-dominated leftist politics.

The second chapter examined the complex relationship between the United States and Great Britain in coordinating policy in British Guiana. Each nation pursued individual strategic objectives in the colony; however, both nations placed the Anglo-American special relationship above their individual interests in the region and ultimately worked together to develop a unified policy toward British Guiana. United States officials were concerned with British Guiana as an aspect of American Cold War geo-strategy while British officials were principally concerned with the logistics of decolonizing their empire. The Cold War and decolonization were two aspects of a global shift in power structure away from European nation states and as such they were intricately related. British Guiana is an excellent example of how the Cold War and decolonization dynamics functioned together in a cyclical relationship. Most importantly, the Cold War and decolonization begat instability; thus, establishing a stable government in British Guiana became the primary concern of both the United States and Great Britain. The AngloAmerican decision to undermine the PPP in British Guiana is best understood as the consequence of the need for stability and American insistence with assuring pro-Western governments in the post-Cuban Revolution Caribbean.

\footnotetext{
Press, 1984); Rishee Thakur, “Politics and Hegemony in Guianese Nationalism, 1945-1965”, Ph.D. Diss., York University, 1994.

${ }^{4}$ For the most effective explanations of the impact of organized labor on Guianese politics see: Robert J. Alexander, A History of Organized Labor in the English -Speaking West Indies (Westport, CT: Praeger, 2004); Kay Saunders, ed. Indentured Labour in the British Empire 1834-1920 (London: Croom Helm Ltd., 1984).
} 
Finally, the third chapter examined the PPP foreign policy and how it impacted American and British decisions in British Guiana. The foreign policies of Guianese nationalist leaders contributed significantly to the independence movement in the colony. Most historians have focused on two aspects of the decolonization process in British Guiana: domestic reform movements and foreign intervention. Their argument has been that the democratically elected PPP government, led by Cheddi Jagan, pursued mild social reform movements and became a victim of American communist paranoia. Most scholars acknowledge that Jagan espoused Marxist ideology, but subordinate the impact of such rhetoric on American policymaking to the significance of upholding a staunch anti-communist ideology. ${ }^{5}$ Thus, traditional historiography has been critical of American intervention in British Guiana. This thesis does not seek to be an apologist for interventionist policies, or to in any way suggest that American interference with the self-determination of developing nations was or is justified. However, this project does suggest that the American decision making process was more complex than has been suggested in the historiography. While this thesis certainly does not blame Jagan for American intervention, it does suggest that the PPP foreign policy was primarily responsible for the Kennedy Administration's decision to support Forbes Burnham. Regardless of the moral judgment history will hold for American Cold War policy, it still needs to be understood why such a policy was pursued. This thesis is primarily concerned with the reasons that the United States and eventually Great Britain were opposed to Cheddi Jagan, and why they chose to subvert his government. United States opposition to Jagan grew in intensity as Jagan’s foreign

\footnotetext{
${ }^{5}$ Richard Barnet, Intervention and Revolution: The United States in the Third World (New York: The World Publishing Company, 1968); Rabe, U.S. Intervention in British Guiana; Spinner, A Political and Social History of Guyana; James L. McDonald, “Overriding Interests: Subversion as an Instrument of U.S. Foreign Policy” (Ph.D. diss., American University, 1997; Jennifer Dale Kibe, "Presidents as Kingmakers: U.S. Decisions to Overthrow Foreign Governments” (Ph.D. Diss., University of California Los Angeles, 2002); Gordon Oliver Daniels, “A Great Injustice to Cheddi Jagan: The Kennedy Administration and British Guiana, 1961-63” (Ph.D. Diss., University of Mississippi, 2000).
} 
policy became more openly communist. It is beyond the scope of this project to evaluate subversion as an aspect of American policy; however, it is important to acknowledge that American intervention was successful in large part because of the complicity of key Guianese, specifically Burnham. Thus, this thesis considers the crucial role of nationalist leaders in British Guiana in creating their own history.

A brief look at Forbes Burnham's policies after independence will serve as a final testament to the agency of nationalist leaders in the developing world and dispense with the notion that Burnham was simply Washington's pawn. During the 1970s Burnham nationalized the economy through the expropriation of foreign enterprises, such as Booker Brothers and Canadian and American bauxite companies. He described his economic policy as a "cooperative socialism”, and it was the exact type of anti-capitalist system that British and American officials hoped to avoid by subverting the PPP and supporting Burnham's government before independence. ${ }^{6}$ Additionally, Burnham actively participated in the non-aligned movement, beginning in 1970, and by the middle of the decade he had established diplomatic relations with the Soviet Union, Cuba, China, and most of Eastern Europe. ${ }^{7}$ However, the true tragedy of Burnham's government was the misery it inflicted on the people of Guyana. Burnham maintained power through fraudulent elections and the repression of the populace. He strengthened the armed forces and used them to suppress the East Indian population with extreme violence. Guyana was one of the poorest, most crime-ridden nations in the world by the end of the 1970s. ${ }^{8}$ Thus, the sad irony of Anglo-American intervention is that in subverting the PPP government to avoid a repressive, corrupt, single party, communist oriented government,

\footnotetext{
${ }^{6}$ Rabe, U.S. Intervention in British Guiana, 164.

${ }^{7}$ Ibid, 166-167.

${ }^{8}$ Ibid, 163-169.
} 
British and American officials were largely responsible for its establishment. However, the Guianese did not sit idly and watch as the United States manipulated the future of their colony. Guianese leaders were actively engaged in international politics and Anglo-American intervention was largely the result of their actions.

\section{Future Research}

There is considerable room for further research on the topics discussed in this thesis. Historians will continue to refine the story of decolonization in British Guiana as more United States documents become declassified. Clearly United States intervention had considerable influence on decolonization in British Guiana; however, the specifics of American involvement remain imprecise due to the considerable number of upper level State Department records on British Guiana which remain classified. Scholars have made use of other archival resources to explore the role of American subversion in the colony; however, the declassification of governmental records will improve on current research. ${ }^{9}$ Scholars will be better able to quantify the effects of American involvement as they more accurately determine the timing and nature of American intervention.

Similarly, there has been little to no research conducted in the archives of the communist nations with which the United States suspected the PPP of having relations. As this paper has shown, there was a significant level of correspondence and travel between PPP members and some Eastern Bloc nations. Examining archives in Cuba, East Germany, Russia, China, and Poland, would allow historians to better ascertain the nature of PPP interaction with those nations and shed light on the Jagans’ intentions for a post-colonial British Guiana, either

\footnotetext{
${ }^{9}$ The AFL-CIO Archives at the George Meaney Library in Silver Spring Maryland, for example, provide an alternative means of obtaining information on the relationship between the Central Intelligence Agency and American based international labor unions.
} 
strengthening or weakening criticism of Anglo-American decisions in the colony. Historians have tended to ignore the possibility that the Jagans were in fact attempting to pursue the type of Castro-like communist government the United States claimed. A comparative study of the early Castro government in Cuba and the Jagans’ plans for British Guiana could be equally enlightening. Evidence which supported the American claims would be cause for a re-evaluation of the criticism surrounding American intervention, even while such studies would not excuse interventionist policies.

Cold War history is becoming increasingly inclusive as historians such as Odd Arne Westad and Jason Parker expand on previous interpretations to incorporate the impact of developing nations on the trajectory of the era. ${ }^{10}$ The trend of de-emphasizing the role of superpower actors will likely continue as more research is conducted in what were previously considered peripheral areas and a more nuanced understanding of the twentieth century will emerge. Additionally, the close relationship between the Cold War and European decolonization will continue to merge as historians explore the shift away from European centers of power after World War II. ${ }^{11}$ Colonized people were always an integral part of global European colonization through collaboration and resistance; however, by the mid-twentieth century, they were affecting the structure of that system of global order unlike any time since the mid-fifteenth century.

Future research will likely strengthen our understanding of the connections between the struggle for autonomy in formerly colonized areas and the efforts of the United States and the Soviet Union to resist drastic change and establish influence in developing areas. British Guiana

\footnotetext{
${ }^{10}$ Odd Arne Westad, The Global Cold War: Third World Interventions and the Making of Our Times (Cambridge University Press, Cambridge, UK: 2005), 3; Jason Parker, Brother's Keeper: The United States, Race, and Empire in the British Caribbean, 1937-1962 (Oxford: Oxford University Press, 2008).

${ }^{11}$ Nial Ferguson, The War of the World: Twentieth-Century Conflict and the Descent of the West (London: Penguin Press, 2006). Ferguson's work explores the twentieth-century as a period of global transition describing the violence of the period as the death throes of a dying world order.
} 
is useful as a historical study in the manner in which it is unique; however, it is most significant because it is not entirely exceptional. The twentieth-century was a period which saw a redefinition of the global power structure and the struggle for supremacy in the re-ordering world took place most actively in formerly colonized areas. The two primary global powers after World War II, the United States and the Soviet Union maneuvered for dominance through ideology and occasionally proxy wars while nationalist leaders sought self-government absent the influence of any foreign power. International organizations such as the United Nations wielded what influence they could to maintain global peace to resolve the conflict of interest resulting from superpower influence and nationalist sentiment. Thus, simultaneously the world fragmented and came together. ${ }^{12}$ The story of the twentieth-century will increasingly cease to be two stories of East-West relations and North-South relations and become an amalgamation of North-SouthEast-West dynamics.

\footnotetext{
${ }^{12}$ Ronald Hyam, Britain's Declining Empire: The Road to Decolonization, 1918-1968 (Cambridge: Cambridge University Press, 2006).
} 


\section{Bibliography:}

\section{Primary Sources:}

The National Archives, Kew, Richmond, Surrey, Colonial Office, Series 1031, Records of the West Indian Department (WIS File Series), 1948-67.

The National Archives, Key, Richmond, Surrey, Foreign Office, Series 10115, General Records of the American Department, (AG File Series), 1906-1966.

United States. Department of State. Central Decimal Files, 1950-63. Record Group 59. National Archives II. College Park, MD.

United States. Department of State. Subject-Numeric Files, 1963-69. Record Group 59. National Archives II. College Park, MD.

Published Government Documents and Records:

United States. Department of State. Foreign Relations of the United States, 1961-63. Washington, D.C.: Government Printing Office, 1996.

United States. Department of State. Foreign Relations of the United States, 1964-68.

Washington, D.C.: Government Printing Office, 2005.

Secondary Sources:

Books:

Agee, Phillip. Inside the Company: CIA Diary, New York: Bantam Books, 1975.

Alexander, Robert J. A History of Organized Labor in the English-Speaking West Indies. Westport, CT: Praeger, 2004.

Ameringer, Charles D. The Democratic Left in Exile: The Antidictatorial Struggle in the Caribbean, 1945-1959, Coral Gables, FL: University of Miami Press, 1974.

Anderson, Benedict. Imagined Communities: Reflections on the Origin and Spread of Nationalism, London: Verso, 1983.

Anderson, David. Histories of the Hanged: Britain's Dirty War and the End of Empire, New York: W.W. Norton and Company, 2005.

Anderson, John Lee. Che Guevara: A Revolutionary Life, New York: Grove Press, 1997.

Barnet, Richard J. Intervention and Revolution: The United States in the Third World, New York: The World Publishing Company, 1968. 
Braveboy-Wagner, Jacqueline Anne. The Venezuela-Guyana Border Dispute: Britain's Colonial Legacy in Latin America. Boulder: Westview Press, 1984.

Cleveland, Grover. The Venezuelan Boundary Controversy. Princeton: Princeton University Press, 1913.

Connelly, Matthew. A Diplomatic Revolution: Algeria's Fight for Independence and the Origins of the Post-Cold War Era. Oxford: Oxford University Press, 2002.

Cudjoe, Selwyn R. Caribbean Visionary: A.R.F. Webber and the Making of the Guyanese Nation. Jackson: University Press of Mississippi, 2009.

Cullather, Nick. Secret History: The CIA's Classified Account of its Operations in Guatemala, 1952-54, Stanford, California: Stanford University Press, 1999.

Despres, Leo A. Cultural Pluralism and Nationalist Politics in British Guiana. Chicago: Rand McNally and Company, 1967.

Ferguson, Nial. The War of the World: Twentieth-Century Conflict and the Descent of the West. London: Penguin Press, 2006.

Horne, Gerald. Cold War in a Hot Zone: The United States Confronts Labor and Independence Struggles in the British West Indies. Philadelphia: Temple University Press, 2007.

Hyam, Ronald. Britain's Declining Empire: The Road to Decolonization, 1918-1968, Cambridge: Cambridge University Press, 2006.

Jagan, Cheddi. The West On Trial: My Fight for Guyana's Freedom. New York: International Publishers, 1966.

Khan, Yasim. The Great Partition: The Making of India and Pakistan, New Haven: Yale University Press, 2007.

Knight, Franklin W., Palmer, Colin A., ed. The Modern Caribbean. Chapel Hill: The University of North Carolina Press, 1989.

Latham, Michael E. Modernization as Ideology: American Social Science and "Nation Building” in the Kennedy Era, Chapel Hill: The University of North Carolina Press, 2000.

Longley, Kyle. The Sparrow and the Hawk: Costa Rica and the United States During the Rise of Jose Figueres, Tuscaloosa: The University of Alabama Press, 1997.

Louis, William Roger. Imperialism at Bay: The United States and the Decolonization of the British Empire 1941-45, New York: Oxford University Press, 1978.

Louis, William Roger. Ends of British Imperialism: The Scramble for Empire, Suez, and Decolonization, London: I.B. Tauris, 2006. 
Palmer, Colin A. Eric Williams and the Making of the Modern Caribbean. Chapel Hill: The University of North Carolina Press, 2006.

Parker, Jason. Brother's Keeper: The United States, Race, and Empire in the British Caribbean, 1937-1962. Oxford: Oxford University Press, 2008.

Rabe, Stephen G. The Most Dangerous Area in the World: John F. Kennedy Confronts Communist Revolution in Latin America Chapel Hill: University of North Carolina Press, 1999.

Rabe, Stephen G. U.S. Intervention in British Guiana: A Cold War Story. Chapel Hill: The University of North Carolina Press, 2005.

Roorda, Eric Paul. The Dictator Next Door: The Good Neighbor Policy and the Trujillo Regime in the Dominican Republic, 1930-1945, Durham: Duke University Press, 1998.

Saunders, Kay, ed. Indentured Labour in the British Empire 1834-1920. London: Croom Helm Ltd., 1984.

Spinner, Thomas. A Political and Social History of Guyana, 1945-1983. Boulder: Westview Press, 1984.

Thorne, Christopher. Allies of a Kind: The United States, Great Britain, and the War Against Japan, 1941-1945, Oxford: Oxford University Press, 1978.

Westad, Odd Arne. The Global Cold War: Third World Interventions and the Making of Our Times, Cambridge University Press, Cambridge, UK: 2005.

Williams, Brackette F. Stains on My Name, War in My Veins: Guyana and the Politics of Cultural Struggle. Durham: Duke University Press, 1991.

Wright, Thomas C. Latin America in the Era of the Cuban Revolution, Westport, CT: Praeger, 2001.

Dissertations and Theses:

Daniels, Gordon Oliver. “A Great Injustice to Cheddi Jagan: The Kennedy Administration and British Guiana, 1961-1963.” Ph.D. Diss., University of Mississippi, 2000.

Kibbe, Jennifer Dale. "Presidents as Kingmakers: U.S. Decisions to Overthrow Foreign Governments”, Ph.D. Diss., University of California Los Angeles, 2002.

McDonald, James, L. “ Subversion as an Instrument of U.S. Foreign Policy”, Ph.D. Diss., American University, 1997.

Thakur, Rishee S. “Politics and Hegemony in Guianese Nationalism, 1945-1965”, Ph.D. Diss., York University, 1994. 